JOSELY EMIKO UMEDA

\title{
ANÁLISE DA EXPRESSÃO GÊNICA APÓS A INTERAÇÃO ENTRE AGGREGATIBACTER ACTINOMYCETEMCOMITANS E CÉLULA EPITELIAL
}

Tese apresentada ao Programa de PósGraduação em Microbiologia do Instituto de Ciências Biomédicas da Universidade de São Paulo, para obtenção do Título de Doutor em Ciências. 
JOSELY EMIKO UMEDA

\section{ANÁLISE DA EXPRESSÃO GÊNICA APÓS A INTERAÇÃO ENTRE AGGREGATIBACTER ACTINOMYCETEMCOMITANS E CÉLULA EPITELIAL}

Tese apresentada ao Programa de PósGraduação em Microbiologia do Instituto de Ciências Biomédicas da Universidade de São Paulo, para obtenção do Título de Doutor em Ciências.

Área de Concentração: Microbiologia

Orientador (a): Profa. Dra. Marcia Pinto Alves Mayer 
DADOS DE CATALOGAÇÃO NA PUBLICAÇÃO (CIP)

Serviço de Biblioteca e Informação Biomédica do

Instituto de Ciências Biomédicas da Universidade de São Paulo

(c) reprodução total

Umeda, Josely Emiko.

Análise da expressão gênica após a interação entre Aggregatibacter actinomycetemcomitans e célula epitelial / Josely Emiko Umeda. -São Paulo, 2010.

Orientador: Marcia Pinto Alves Mayer.

Tese (Doutorado) - Universidade de São Paulo. Instituto de Ciências Biomédicas. Departamento de Microbiologia. Área de concentração: Microbiologia. Linha de pesquisa: Microbiologia oral

Versão do título para o inglês: Gene expression analysis after interaction between Aggregatibacter actinomycetemcomitans and epithelial cell.

Descritores: 1. Doença periodontal 2. Aggregatibacter actinomycetemcomitans 3 . Fatores de virulência 4. Citocinas 5. Inflamação 6. Expressão gênica I. Mayer, Marcia Pinto Alves II. Universidade de São Paulo. Instituto de Ciências Biomédicas.

Programa de Pós-Graduação em Microbiologia III. Título. 


\section{UNIVERSIDADE DE SÃO PAULO INSTITUTO DE CIÊNCIAS BIOMÉDICAS}

Candidato(a):
Josely Emiko Umeda.
Título da Tese: $\quad \begin{aligned} & \text { Análise da expressão gênica após a interação entre } \\ & \text { Aggregatibacter actinomycetemcomitans e célula epitelial }\end{aligned}$

Orientador(a):

Marcia Pinto Alves Mayer.

A Comissão Julgadora dos trabalhos de Defesa da Tese de Doutorado, em sessão pública realizada a .................., considerou

\section{( ) Aprovado(a) ( ) Reprovado(a)}

$\begin{array}{ll}\text { Examinador(a): } & \text { Assinatura: } \\ & \text { Nome: } \\ & \text { Instituição: } \\ \text { Examinador(a): } & \text { Assinatura: } \\ & \text { Nome: } \\ & \text { Instituição: } \\ \text { Examinador(a): } & \text { Assinatura: } \\ & \text { Nome: } \\ & \text { Instituição: } \\ & \text { Assinatura: } \\ & \text { Nome: } \\ & \text { Instituição: } \\ \text { Presidente: } & \text { Assinatura: } \\ & \text { Nome: } \\ & \text { Instituição: }\end{array}$




\section{CERTIFICADO DE ISENÇÃO}

Certificamos que o Protocolo CEP-ICB N 135, referente ao projeto intitulado "Análise da expressão génica após a interação entre Actinobacillus actinomycetemcomitans e célula epiteliaf sob a responsabilidade de Josely Emiko Umeda, foi analisado na presente data pela CEEA - COMISSÃO DE ÉTICA EM EXPERIMENTAÇÃO ANIMAL e pela CEPSH - COMISSÃO DE ÉTICA EM PESQUISA COM SERES HUMANOS, tendo sido deliberado que o referido projeto não envolve manipulação animal ou humana que justifique uma aprovação quanto aos princípios éticos exigidos por ambas as Comissões.

São Paulo, 23 de fevereiro de 2006.
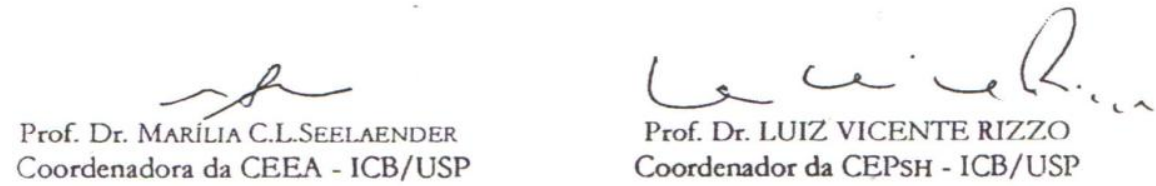


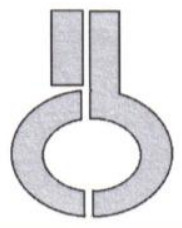

UNIVERSIDADE DE SÃO PAULO

INSTITUTO DE CIÊNCIAS BIOMÉDICAS

Cidade Universitária "Armando de Salles Oliveira"

Av. Prof. Lineu Prestes, 2415 - cep. 05508-000 Săo Paulo, SP - Brasil

Telefone: (55) (011) 3091.7733 - telefax: (55) (011) 3091.7438

e-mail: cep@icb.usp.br

Decl. CEPSH.137.09

\section{DECLARAÇÃ O}

Em adendo ao Protocolo CEP-ICB Nº 135, de 23.02.09, aprovo

a inclusão de amostras de tecido gengival de humano ao Projeto intitulado: "Análise da expressão gênica após a interação entre Actinobacillus actinomycetemcomitans e célula epitelial" sob responsabilidade da pesquisadora Josely Emiko Umeda, não apresentando restrições quanto às modificações do protocolo, que as mesmas não afetam os aspectos éticos da pesquisa.

São Paulo, 16 de dezembro de 2009.

Atenciosamente,

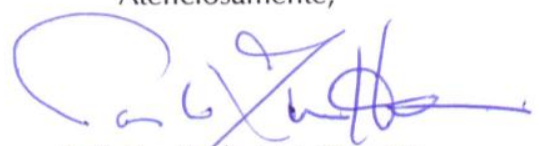

Prof. Dr. Paolo M.A.Zanotto

Vice-Coordenador da Comissão de Ética em

Pesquisas com Seres Humanos - ICB /USP

Comissão de Ética em Pesquisa com Seres Humanos do Instituto de Ciências Biomédicas - USP Aprovada pela Comissão Nacional de Ética em Pesquisa - CONEP, em 10 de fevereiro de 1998. 


\section{UnG CEPPE

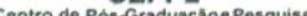

Comitê de Ética em Pesquisa

Guarulhos, 08 de setembro de 2009

Exmo. Sr.

Marcelo de Faveri

Referência: Aprovaçăo de Projeto

SISNEPI496 - "Associaçăo do complexo imune com a perda óssea periodontal"

\section{PARECER No 190/2009}

- Comitê de Ética em Pesquisa da Universidade Guarulhos analisou o Projeto de Pesquisa de sua autoria "Associaçăo do complexo imune com a perda óssea periodontal" - SISNEP/496, na reuniấo de 01.09.2009, e no uso das competências definidas na Res. CNS 196/96, considerou o projeto acima aprovado.

As orientaçōes abaixo devem ser consideradas pelo Pesquisador Responsável durante a realizaçăo da pesquisa, visando que a mesma se desenvolva respeitando os padrões éticos:

- O sujeito da pesquisa tem a liberdade de recusar-se a participar ou de retirar seu consentimento em qualquer fase da pesquisa, sem penalizaçăo alguma e sem prejuizo ao seu cuidado e deve receber uma cópia do Termo de Consentimento Livre e Esclarecido, na integra, por ele assinado.

- O pesquisador deve desenvolver a pesquisa conforme delineada no protocolo aprovado e descontinuar o estudo somente após análise das razőes da descontinuidade pelo CEP que o aprovou, aguardando seu parecer, exceto quando perceber risco ou dano nâo previsto ao sujeito participante ou quando constatar a superioridade de regime oferecido a um dos grupos da pesquisa que requeiram açăo imediata.

- Eventuais modificações ou emendas e eventos adversos ao protocolo, devem ser apresentadas ao CEP de forma clara e sucinta, identificando a parte do protocolo a ser modificada e suas justificativas.

- Esclarecemos a necessidade da apresentaçăo de relatório final até 30.10.11.

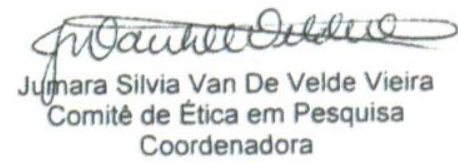


Dedico este trabalho a Deus e aos mens pais Toshihide e Terumi, peto incentivo em todos os momentos e ensinamentos dos valores da vida. 


\section{AGRADECIMENTOS}

À minha orientadora Profa. Dra. Marcia Pinto Alves Mayer, a quem tenho muita admiração e eterna gratidão pela orientação e amizade

Às minhas irmãs Josyane, Arianne e Érica por terem compartithado comigo os bons momentos e também os dificeis,

Aos mens sobrinhos Thiago, Rafael e Gútia pela alegria que me proporcionaram

À Fundação de Amparo à Pesquisa do Estado de São Paulo (FAPESP) pelos recursos concedidos para a reatização deste trabatho e pela oportunidade da reatização do doutorado sanduiche nos EUA

Aos queridos amigos de labortório Adriana, Amanda, Ana Carla, César, Clau Ota, Claudinha, Carol, Cristina, Dídi, Ellen, Éricka, Felipe, Flávia, João, Léo, Líliane, Lucas, Mayke, Pâmela, Priscila, Sítvia, Talyta, pelo ajuda, amizade e carinho que recebi de todos vocês.

Ao Prof. Dr. Donald Demuth pelo incentivo e por ter me aceito trabalhar em seu laboratório

À Rosana Prisco pela ajuda na análise estatitistica do trabalho 
Aos amigos do laboratório do Prof. Dr. Donald: Carlo, Han Juan, Lisa, Deanne, Liz, pela troca de experiencias

Ao Prof. Dr. Kinane e Dr. Johnah peto apoio

À Profa. Dra. Ana Clara e seus alunos por terem cedido um espaço para a utilização do termociclador possibititando a reatização das reações de PCR em tempo reat

Ao Prof. Dr. Marcelo de Faveri pela doação das amostras de tecido gengival dos pacientes da Universidade de Guarulhos após aprovação do Comitê de Ética

Às queridas amigas da república Juliana, Ananda, Cübely e Sheila pela amizade, paciêncía e compreensão

Às secretárias Alice, Aninha e Naide pela ajuda de sempre

A todos que colaboraram com esse trabalho

O meu sincero agradecimento! 
"O vento é $\sigma$ mesmo, mas sua resposta é diferente em cada folha."

Cecítia Meireles 
Este trabalho foi financiado pela Fundação de Amparo à Pesquisa do Estado de São Pauto (FAPESP) processos número: 03/08598-0 e 05/58903-0 


\section{RESUMO}

UMEDA, J. E. Análise da expressão gênica após a interação entre Aggregatibacter actinomycetemcomitans e célula epitelial. 2010. 125 f. Tese (Doutorado em Microbiologia) Instituto de Ciências Biomédicas, Universidade de São Paulo, São Paulo, 2010.

Aggregatibacter (Actinobacillus) actinomycetemcomitans, associado à etiologia da periodontite agressiva localizada, apresenta vários fatores de virulência, destacando-se a adesão e invasão às células epiteliais, e produção de leucotoxina e toxina distensora citoletal. Durante a infecção, bactérias patogênicas induzem a ativação ou inibição das vias de sinalização do hospedeiro, além de alterarem a expressão de genes bacterianos, visando a sua sobrevivência aos desafios oferecidos pelo novo ambiente. Objetivos: Visando contribuir no entendimento da interação entre A. actinomycetemcomitans e o hospedeiro, o objetivo do presente estudo foi determinar a transcrição de genes bacterianos relacionados à virulência e a resposta da célula eucarionte após a interação entre A. actinomycetemcomitans e células epiteliais gengivais imortalizadas OBA-9. Métodos: cepas de referência de A. actinomycetemcomitans JP2 (sorotipo b), SUNY 465 (sorotipo b), e ATCC 29523 (sorotipo a), foram co-cultivadas com células epiteliais gengivais OBA-09 por períodos de 2 e 24 horas. A transcrição relativa dos genes omp100 (apiA), aae, ltx, flp, apaH, omp29, vppA, cdtB, vapA, orf 859, cagE, emaA e $p g A$ de A. actinomycetemcomitans foi determinada, por RT-qPCR. A transcrição de 84 genes associados à via de transdução de sinais em células epiteliais foi analisada por Arranjos RT-qPCR após 24 horas de co-cultura com a amostra A. actinomycetemcomitans JP2. Como controles foram utilizadas as cepas bacterianas ou células gengivais isoladamente. A concentração dos mediadores inflamatórios GM-CSF, TNF- $\alpha$ e ICAM-1, cuja expressão gênica foi regulada positivamente após interação com a bactéria foi determinada por ELISA no sobrenadante das células epiteliais gengivais infectadas e em amostras de tecido gengival de indivíduos com periodonto saudável $(\mathrm{n}=12)$, de pacientes com periodontite agressiva $(n=10)$ e com periodontite crônica $(n=11)$. Resultados: Foram observadas diferenças na expressão dos genes de virulência entre as amostras ATCC29523, SUNY 465 e JP2 no controle e após 2 e 24 horas de infecção. Na condição controle em 2 horas, a amostra JP2 apresentou níveis mais elevados de transcritos dos genes apaH, ltx, $c d t B, v p p A$ e omp29 do que as amostras SUNY 465 e ATCC29523. No entanto, após 24 h de interação com célula epitelial, a amostra ATCC29523 mostrou regulação positiva dos genes aae, apaH, flp, apresentando o maior nível de transcrição dos genes codificando proteínas de adesão. A interação com células epitelias 
após 24 h induziu a transcrição de ltx a níveis similares pelas amostras consideradas produtoras de níveis baixos (SUNY465) e altos de leucotoxina (JP2), ambas do sorotipo b, enquanto a trasncrição de ltx pela amostra (sorotipo a) manteve-se em baixos níveis. Os genes omp29 e cagE foram transcritos apenas nas amostras JP2 e SUNY465 (sorotipo b), sendo estes valores superiores para a cepa JP2. O gene $p g A$ foi regulado positivamente após 2 e 24 h de interação com célula epitelial em todas as amostras testadas. Entre 84 genes testados, quinze foram regulados positivamente nas células OBA-09 após interação com A. actinomycetemcomitans ( $\mathrm{p}<0,01)$. Os genes csf2, tnf- $\alpha$, egr-1 e icam-1 foram transcritos 170; 28,93; 14,08 e 7,67 vezes mais após a infecção em relação ao controle. A análise dos mediadores inflamatórios GM-CSF, TNF- $\alpha$ e ICAM-1 confirmou que estas citocinas são expressas por células epiteliais gengivais infectadas e apresentam-se em concentrações estatisticamente superiores nos tecidos gengivais de pacientes com periodontite em relação aos indivíduos saudáveis, embora não tenham sido observadas diferenças entre periodontite agressiva e crônica. Conclusões: A maior transcrição de genes associados à virulência como omp29 e ltx pelas amostras A.actinomycetemcomitans sorotipo b, justificam a maior virulência. A regulação positiva de ltx após contato com célula por 24 h na amostra SUNY 465 sugere que amostras sorotipo b não pertencentes ao clone JP2 poderiam expressar, in vivo, níveis de leucotoxina similares aos do clone JP2, justificando sua alta prevalência na periodontite agressiva. Por outro lado, a interação de $A$. actinomycetemcomitans sorotipo a com células epiteliais induziu a transcrição de genes que codificam adesinas como aae e $a p a H$ e do operon $c d t$. A regulação positiva da transcrição de genes de células epiteliais associados às vias de sinalização, como csf2 e tnf- $\alpha$ após a infecção por A.actinomycetemcomitans, demonstra que o cenário da periodontite agressiva, caracterizado por infiltrado macrofágico e destruição óssea, pode ter início precocemente durante a infecção, após a interação da bactéria com o epitélio.

Palavras-chave: Doença periodontal. Aggregatibacter actinomycetemcomitans. Fatores de virulência. Citocinas. Inflamação. Expressão gênica. 


\begin{abstract}
UMEDA, J. E. Gene expression analysis after interaction between Aggregatibacter actinomycetemcomitans and epithelial cell. 2010. 125 p. Ph.D. Thesis (Microbiology) Instituto de Ciências Biomédicas, Universidade de São Paulo, São Paulo, 2010.
\end{abstract}

Aggregatibacter (Actinobacillus) actinomycetemcomitans, associated to the etiology of localized aggressive periodontitis, produces several virulence factors, mainly the adhesion and invasion to epithelial cells, and production of leucotoxin and cytolethal distending toxin. During the infection, pathogenic bacteria induce the activation or inhibition of signaling pathways of the host, in addition to altering the bacterial gene expression, favouring to survive the challenges offered by the new environment. Objective: Aiming to contribute in the understanding of the interaction between A. actinomycetemcomitans and the host, the objective of this study was to determine the transcription of bacterial genes related to the virulence and the response of the eukaryotic cell after the interaction between A. actinomycetemcomitans and immortalized gingival epithelial OBA-9 cells. Methods: reference strains of A. actinomycetemcomitans JP2 (sorotype b), SUNY 465 (sorotype b), and ATCC 29523 (sorotype a), were co-cultured with OBA-9 cells for bacterial gene expression analysis in 2 and 24 hours of infection. The relative transcription of omp100 (apiA), aae, ltx, flp, apaH, omp29, vppA, cdtB, vapA, orf 859, cagE, emaA and $p g A$ genes of $A$. actinomycetemcomitans was determined after adhesion with epithelial cells by RT-qPCR. The profile of transcription of 84 genes related to signaling transduction in epithelial cells were analysed by RT-qPCR Arrays after 24 hours of infection with $A$. actinomycetemcomitans JP2. Isolated bacterial strains or gingival cells were used as control. The concentration of GM-CSF, TNF- $\alpha$ and ICAM-1, that were up-regulated inflammatory mediators after interaction with bacteria, were determined by ELISA in the supernatant of infected gingival epithelial cells and in gingival tissue of patients with aggressive periodontitis $(n=10)$, chronic periodontitis $(n=11)$ and periodontally health subjects $(n=12)$. Results: differences were observed in the expression of virulence genes among ATCC29523, SUNY 465 and JP2 strains in control and after 2 and 24 hours of infection. In 2 hours of the control condition, the strain JP2 showed the highest levels of apaH, ltx, cdtB, vppA and omp29 transcript genes than SUNY 465 and ATCC29523. However, after 24 hours of interaction, the ATCC 29523 strain showed upregulation of aae, apaH, flp genes with highest levels of transcript genes coding adhesion 
proteins. In addition, the interaction with epithelial cells after 24 hours reach similar levels of mRNA of ltx between minimally leukotoxic strains (SUNY465) and highly leukotoxic (JP2), both serotype $\mathbf{b}$, while the a serotype maintains lowest levels. The omp29 and cagE genes, were transcripted only by JP2 and SUNY465, and highest levels was showed by JP2. The $p g A$ gene was up-regulated after 2 and 24 hours of infection for all analysed strains. In relation the gene expression of gingival epithelial cells OBA-9 after infection with A. actinomycetemcomitans, it was demonstrated 15 up-regulated genes compared with control without bacteria $(\mathrm{p}<0.01)$. The csf2, tnf- $\alpha$, egr-1 and icam-1 genes were transcribed 170, 28.93, 14.08 and 7.67 fold change more compared with control. The functional analysis of inflammatory mediators GM-CSF, TNF$\alpha$ and ICAM-1, confirmed that these cytokines are expressed by infected gingival epithelial cells and showed statically highest concentration in the gingival tissues of periodontitis patients in relation to health individuals, although there were not observed differences between diseases aggressive and chronic. Conclusions: the highest trancription of genes associated to the virulence, such as omp29 and ltx by A.actinomycetemcomitans strains serotype $\mathbf{b}$, justifying the highest virulence. The up-regulation of ltx gene after contact with cells in 24 hours by SUNY 465 strain, suggest that the presence of serotype b non JP2-like would be express, in vivo, at similar levels of leucotoxin by the JP2 like, justifying the high prevalence in the aggressive periodontitis. By the other side, the interaction of A.actinomycetemcomitans serotype a with epithelial cells induced the transcription genes that encoded adhesins, such as aae, apaH and cdt operon. The up-regulation of transcription of genes by epithelial cells associated with signaling transduction as csf 2 and tnf- $\alpha$ after infection by A.actinomycetemcomitans, it demonstrates that the scenarium of the aggressive periodontitis, characterized with macrophage infiltrate and bone destruction, begins early during the infection, after the interaction of the bacterium with the epithelium.

Key words: Periodontal disease. Aggregatibacter actinomycetemcomitans. Virulence factors. Cytokines. Inflammation. Gene expression. 


\section{LISTA DE ILUSTRAÇÕES}

Figura 1- Lócus tad de A. actinomycetemcomitans.

Figura 2- Vias de sinalização MAPK. As vias de sinalização MAPK estão organizadas em módulos de cascatas em que a ativação por receptores da superfície celular das quinases antecedentes levam à ativação sequencial de um módulo MAPK (MAPKKK $\rightarrow$ MAPKK $\rightarrow$ MAPK). O esquema ilustra os componentes da via principal MAPK e exemplos das proteínas alvo da via MAPK. As quinases alvo estão em negrito. As linhas indicam as conexões de sinalização contexto-dependente entre os módulos MAPK

Figura 3- Expressão gênica relativa do gene $f l p$ após adesão a célula epitelial gengival OBA-9 em 2 horas (A) e 24 horas (B), em relação ao controle (sem a presença da célula epitelial). Teste Anova-Tukey, diferença estatisticamente significante foi considerada quando $* \mathrm{p}<0,05$......

Figura 4- Expressão gênica relativa do gene aae após adesão a célula epitelial gengival OBA-9 em 2 horas (A) e 24 horas (B), em relação ao controle (sem a presença da célula epitelial). Teste Anova-Tukey,, diferença estatisticamente significante foi considerada quando $* \mathrm{p}<0,05$.

Figura 5- Expressão gênica relativa do gene $a p a H$ após adesão a célula epitelial gengival OBA9 em 2 horas (A) e 24 horas (B), em relação ao controle (sem a presença da célula epitelial). Teste Anova-Tukey, diferença estatisticamente significante foi considerada quando * $\mathrm{p}<0,05 \ldots 66$

Figura 6- Expressão gênica relativa do gene omp100 após adesão a célula epitelial gengival OBA-9 em 2 horas (A) e 24 horas (B), em relação ao controle (sem a presença da célula epitelial). Teste Anova-Tukey, diferença estatisticamente significante foi considerada quando * $\mathrm{p}<0,05$.

Figura 7- Expressão gênica relativa do gene emaA após adesão a célula epitelial gengival OBA9 em 2 horas (A) e 24 horas (B), em relação ao controle (sem a presença da célula epitelial). Teste Anova-Tukey, diferença estatisticamente significante foi considerada quando $* \mathrm{p}<0,05 \ldots 67$

Figura 8- Expressão gênica relativa do gene ltx após adesão a célula epitelial gengival OBA-9 em 2 horas (A) e 24 horas (B), em relação ao controle (sem a presença da célula epitelial). Teste Anova-Tukey, diferença estatisticamente significante foi considerada quando $* \mathrm{p}<0,05$...... .67

Figura 9- Expressão gênica relativa do gene $c d t B$ após adesão a célula epitelial gengival OBA-9 em 2 horas (A) e 24 horas (B), em relação ao controle (sem a presença da célula epitelial). Teste Anova-Tukey, diferença estatisticamente significante foi considerada quando $* \mathrm{p}<0,05$. . .68

Figura 10- Expressão gênica relativa do gene $v p p A$ após adesão a célula epitelial gengival OBA9 em 2 horas (A) e 24 horas (B), em relação ao controle (sem a presença da célula epitelial). Teste Anova-Tukey, diferença estatisticamente significante foi considerada quando * $\mathrm{p}<0,05 . .68$ 
Figura 11- Expressão gênica relativa do gene orf859 após adesão a célula epitelial gengival OBA-9 em 2 horas (A) e 24 horas (B), em relação ao controle (sem a presença da célula epitelial). Teste Anova-Tukey, diferença estatisticamente significante foi considerada quando * $\mathrm{p}<0,05$.

Figura 12- Expressão gênica relativa do gene vapA após adesão a célula epitelial gengival OBA9 em 2 horas (A) e 24 horas (B), em relação ao controle (sem a presença da célula epitelial). Teste Anova-Tukey, diferença estatisticamente significante foi considerada quando * $\mathrm{p}<0,05 \ldots 69$

Figura 13- Expressão gênica relativa do gene cagE após adesão a célula epitelial gengival OBA9 em 2 horas (A) e 24 horas (B), em relação ao controle (sem a presença da célula epitelial). Teste Anova-Tukey, diferença estatisticamente significante foi considerada quando $* \mathrm{p}<0,05 \ldots 70$

Figura 14- Expressão gênica relativa do gene omp29 após adesão a célula epitelial gengival OBA-9 em 2 horas (A) e 24 horas (B), em relação ao controle (sem a presença da célula epitelial). Teste Anova-Tukey, diferença estatisticamente significante foi considerada quando * $\mathrm{p}<0,05$. .70

Figura 15- Expressão gênica relativa do gene $p g A$ após adesão a célula epitelial gengival OBA-9 em 2 horas (A) e 24 horas (B), em relação ao controle (sem a presença da célula epitelial). Teste Anova-Tukey, diferença estatisticamente significante foi considerada quando $* \mathrm{p}<0,05$. .71

Figura 16- Número de células bacterianas recuperadas após ensaio de adesão em célula epitelial gengival (OBA-9) das amostras de Aggregatibacter actinomycetemcomitans 652 e JP2 nos intervalos de 2,12 e 24 horas de infecção. .72

Figura 17- Número de células bacterianas recuperadas após ensaio de invasão em célula epitelial gengival (OBA-9) da amostra de Aggregatibacter actinomycetemcomitans JP2 nos intervalos de 2, 12 e 24 horas de infecção. Resultados em triplicata de três ensaios independentes. .72

Figura 18- Níveis de mediadores inflamatórios (CSF-2 - em A, TNF- $\alpha$ em B e ICAM-1 em C) determinados por ELISA no sobrenadante de células epiteliais gengivais OBA-9 após 24 horas de infecção com a amostra A. actinomycetemcomitans JP2 a uma MOI de 1:100. Controle: células epiteliais sem adição da bactéria. Teste $\mathrm{t}$ de Student, diferença estatisticamente significante foi considerada quando, $* \mathrm{p}<0,05$ .76

Figura 19- Níveis de TNF- $\alpha$ determinados por ELISA em meio de cultura adicionado de 2.000 $\mathrm{pg} / \mathrm{ml}$ de TNF- $\alpha$, seguindo-se incubação por diferentes intervalos de tempo. Controle - apenas o meio de cultura [KFSM (Invitrogen)] contendo TNF- $\alpha$. JP2 - meio de cultura contendo TNF- $\alpha$ e inoculado com $3 \times 10^{7} \mathrm{UFC}$ A. actinomycetemcomitans JP2/ml. Diferenças estatisticamente significantes (ANOVA, * $\mathrm{p}<0,05 ; * * \mathrm{p}<0,01 ; * * * \mathrm{p}<0,001$ ) em relação ao controle sem incubação (tempo 0 horas). .77

Figura 20- Distribuição dos níveis de mediadores inflamatórios (CSF-2 em A, TNF- $\alpha$ em B, ICAM-1 em C) determinados por ELISA em amostras de tecido gengival de pacientes com periodontite agressiva (PAG), periodontite crônica (PC) e indivíduos com periodonto saudável 
(SAUD). Teste de Kruskal-Wallis, diferença estatisticamente significante foi considerada

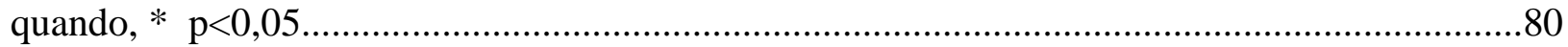




\section{LISTA DE TABELAS}

Tabela 1- Relação das cepas padrão utilizadas para os ensaios de expressão gênica bacteriana.

Tabela 2- Concentração de Cloreto de Magnésio $\left(\mathrm{MgCl}_{2}\right)$ utilizada nas reações de PCR em tempo real para cada par de iniciador.

Tabela 3- Seqüência dos iniciadores utilizados em reações de PCR em tempo real para análise da actinomycetemcomitans gênica de

Tabela 4- Valores médios dos níveis de transcrição de cada um dos genes normalizados em relação à transcrição de gapdH das três amostras de A. actinomycetemcomitans na condição controle sem célula epitelial após 2 hs de incubação (Média \pm Desvio padrão). AS (ausência de significância entre amostras).

Tabela 5- Valores médios dos níveis de transcrição de cada um dos genes normalizados em relação à transcrição de gapdH das três amostras de A. actinomycetemcomitans após adesão em 2 hs de incubação (Média \pm Desvio padrão). AS (ausência de significância entre amostras)

Tabela 6- Valores médios dos níveis de transcrição de cada um dos genes normalizados em relação à transcrição de gapdH das três amostras de A. actinomycetemcomitans na condição controle sem célula epitelial após 24 hs de incubação (Média \pm Desvio padrão). AS (ausência de significância entre amostras).

Tabela 7- Valores médios dos níveis de transcrição de cada um dos genes normalizados em relação à transcrição de gapdH das três amostras de A. actinomycetemcomitans após adesão em 24 hs de incubação (Média \pm Desvio padrão). AS (ausência de significância entre amostras)....64

Tabela 8- Proteínas cujos genes codificadores foram regulados positivamente na via de transdução de sinais da célula epitelial gengival OBA-9, após 24 horas de infecção com a amostra JP2 em relação ao controle sem a presença da bactéria. Teste T de Student foi empregado para comparar os níveis de transcritos nas células não infectadas (controle) e após a infecção. Valores de $\mathrm{p}<0,01$ foram considerados significantes. . .74

Tabela 9- Valores da mediana das concentrações de GM-CSF/CSF2, TNF- $\alpha$ e ICAM-1 em $\mathrm{ng} / \mathrm{ml}$ encontrados nas amostras de tecido gengival dos indivíduos periodontalmente saudáveis e pacientes apresentando periodontite agressiva e crônica. 


\section{LISTA DE ABREVIATURAS E SIGLAS}

A.actinomycetemcomitans - Aggregatibacter actinomycetemcomitans

BIRC3 - proteína baculovital contendo sequências repetidas IAP3

$\mathrm{CCL}$ - quimiocinas

CDT - toxina distensora citoletal

CDKN1A - Inibidor quinase ciclina dependente 1A

$\mathrm{CO}_{2}$ - dióxido de carbono

CSF2 - fator estimulador de colônias 2 ou fator de estimulação de granulócitos e macrófagos

$\mathrm{C}_{\mathrm{T}}$ - ciclo Threshold

dNTP - desoxirribonucleotídeos trifosfato

DO - densidade óptica

DspB - dispersina B

EGF - fator de crescimento epidérmico

EGR1 - resposta de crescimento precoce 1

ELISA - ensaio imunoenzimático

EMA - proteína ligante a colágeno

FGF - fator de crescimento do fibroblasto

Flp - proteína fimbrial

FOS - homólogo ao oncogene murino de osteossarcoma viral V-fos FBJ

$\mathrm{g}$ - gravidade

GADD45A - fator de interrupção de crescimento e indutor de dano no DNA, alfa

GREB1 - proteína GREB1

$\mathrm{h}$ - horas

Ig - imunoglobulina

$\mathrm{IL}$ - interleucina

ICAM-1- molécula de adesão intercelular -1

IRF - fator regulador de Interferon 1

JUN - Jun oncogene

$\mathrm{kDa}$ - kilodalton 
LPS - lipopolissacarídeo

ltx - leucotoxina

$\mu \mathrm{g}-$ micrograma

$\mu \mathrm{l}-$ microlitros

$\mathrm{mg}$ - miligrama

$\mathrm{M}$ - molar

$\mathrm{MgCl}_{2}$ - cloreto de magnésio

$\min -$ minuto

$\mathrm{ml}$ - mililitros

mm - milímetros

$\mathrm{mM}$ - milimolar

MOI- multiplicidade de infecção

$\mathrm{n}$ - número

NF-kB - fator nuclear kappaB

ng - nanograma

nm - nanômetro

OBA-9- linhagem de células epiteliais gengivais

OMP - proteína de membrana externa

PAgG - periodontite agressiva generalizada

PAgL - periodontite agressiva localizada

$\mathrm{pb}$ - pares de base

PBS - solução salina tamponada fosfatada

PC - periodontite crônica

PCR - reação de polimerase em cadeia

PGA - polímero linear de resíduos N-acetil-D-glicosamina

$\mathrm{pH}$ - potencial hidrogeniônico

$\mathrm{PM}$ - peso molecular

PMN - polimorfonucleares

qPCR - reação de polimerase em cadeia quantitativa

rpm - rotações por minuto

$\mathrm{s}-$ segundos 
TLR - receptor toll- like

$\mathrm{TNF}$ - fator de necrose tumoral

TSBYE - meio triptone soja acrescido de extrato de levedura

UFC - unidades formadoras de colônias

VEGFA - fator de crescimento de endotélio vascular A 


\section{SUMÁRIO}

1 INTRODUÇÃO

2 OBJETIVOS.

3 MATERIAL E MÉTODOS

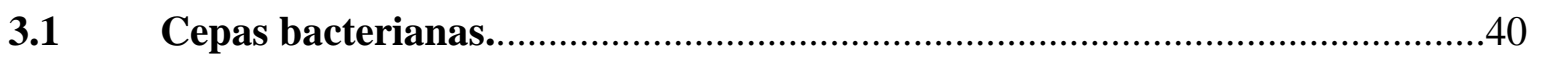

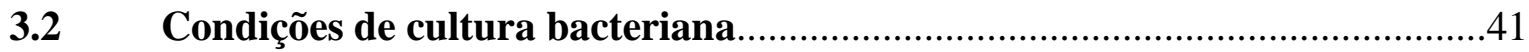

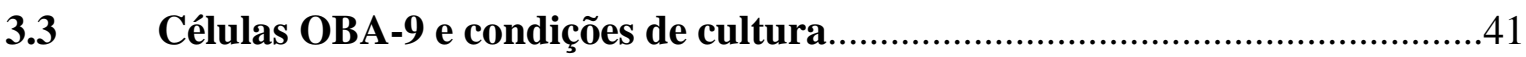

3.4 Adesão de Aggregatibacter actinomycetemcomitans à célula epitelial.............42

3.5 Análise da transcrição gênica bacteriana..............................................................43

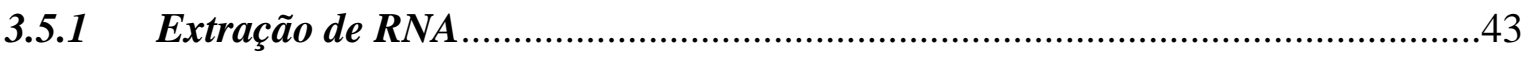

3.5.2 RT-PCR

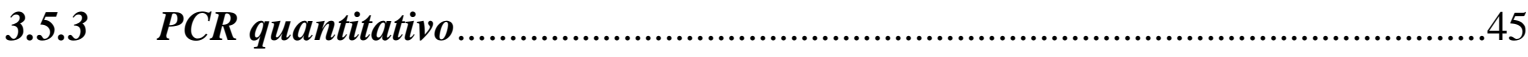

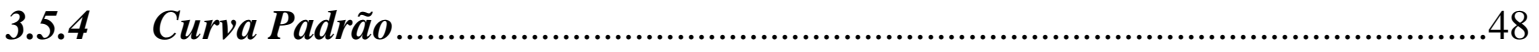

3.6 Análise da transcrição gênica da célula epitelial OBA-9 por Array

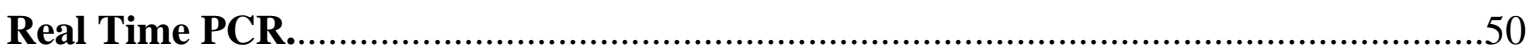

3.6.1 Condições de cultura bacteriana ...................................................................50

3.6.2 Adesão de Aggregatibacter actinomycetemcomitans à célula epitelial em

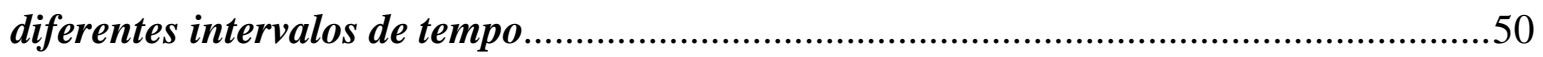

3.6.3 Invasão de Aggregatibacter actinomycetemcomitans à célula epitelial em diferentes intervalos de tempo.

3.6.4 Análise da transcrição gênica da célula epitelial OBA-9 após 24 horas de

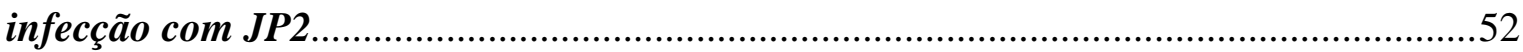

3.7 Ensaio Imunoenzimático (ELISA) para deteç̧ão de GM-CSF/CSF2,

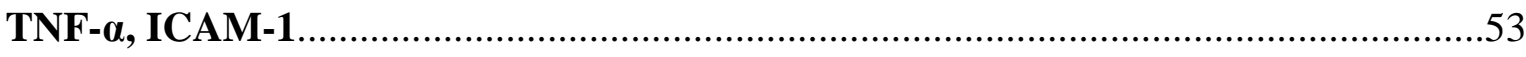

3.7.1 Análise no sobrenadante de cultura de células in vitro.......................................53

3.7.2 Análise em amostras de tecido gengival..........................................................54

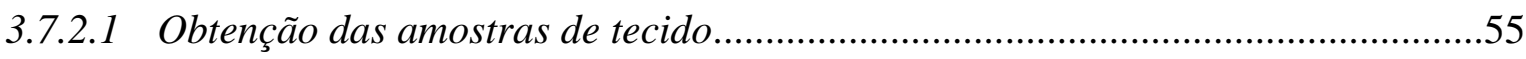

3.7.2.2 Processamento das amostras de tecido gengival...............................................55 


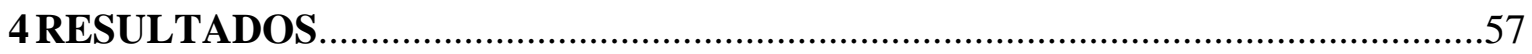

4.5 Adesão de Aggregatibacter actinomycetemcomitans às células epiteliais.........57

4.6 Análise da expressão gênica de Aggregatibacter actinomycetemcomitans após a adesão a célula epitelial gengival OBA-9 e no controle sem a presença da célula epitelial.

4.7 Adesão e Invasão de Aggregatibacter actinomycetemcomitans à célula epitelial OBA-9 em diferentes intervalos de tempo.

4.8 Análise da expressão gênica da célula epitelial OBA-9 após 24 de

infecção com JP2.

4.9 Detecção de GM-CSF/CSF2, TNF- $\alpha$ e ICAM-1 no sobrenadante de culturas celulares.

4.10 Detecção de GM-CSF/CSF2, TNF- $\alpha$ e ICAM-1 em amostras de tecido gengival de indivíduos saudáveis e pacientes com periodontite (agressiva e crônica).

ANEXOS

ANEXO A- Arranjo dos 96 pares de iniciadores da via de transdução de sinais de célula humana do kit $\mathrm{RT}^{2}$ Profiler PCR Array Human Signal Transduction PathwayFinder (PAHS-014A).

ANEXO B- Relação dos valores médios das concentrações das citocinas obtidas para cada amostra de tecido gengival pacientes apresentado diferentes condições periodontais: periodontite agressiva $(\mathrm{PAG})$, periodontite crônica (PC) e periodonto saudável (S) 


\section{INTRODUÇÃO}

A periodontite é uma doença inflamatória das estruturas do periodonto associada à colonização do sulco subgengival por bactérias anaeróbias Gram-negativas específicas (SLOTS, 1986; MINTZ et al., 2004). Dentre estas bactérias destaca-se Aggregatibacter actinomycetemcomitans, denominado anteriormente como Actinobacillus actinomycetemcomitans e reclassificado no gênero Aggregatibacter juntamente com outras espécies orais como A. aphrophilus (anteriormente Haemophilus aphrophilus) e A. paraphrophilus (anteriormente Haemophilus paraphrophilus) (NORSKOV-LAURITSEN e KILIAN, 2006). A .actinomycetemcomitans é um cocobacilo, fermentativo, Gram negativo e capnofílico, associado à periodontite agressiva localizada, podendo ser encontrado também em pacientes com periodonto saudável (FIVES-TAYLOR et al., 1999; LI et al., 2004; YANG et al., 2004; WILSON e HENDERSON, 1995; MEYER e FIVES-TAYLOR, 1997; ZAMBON et al., 1985; FAVERI et al., 2009). A forte correlação entre A. actinomycetemcomitans e a doença periodontal foi evidenciada em estudos clínicos, microbiológicos e de resposta imune (SLOTS e GENCO, 1984; ZAMBON et al., 1985). A. actinomycetemcomitans pode ainda ser associado a infecções extra-orais como endocardite, bacteremia, septicemia, meningite, pneumonia, osteomielite, infecções do trato urinário e abcessos (PATUREL et al., 2004; HENDERSON et al., 2003; PAGE e KING, 1966; MUHLE; RAU; RUSKIN, 1979).

A. actinomycetemcomitans apresenta seis sorotipos: a, b, c, d e, f; sendo o sorotipo b, o mais freqüente nos casos de periodontite agressiva e infecções extra-orais como endocardite (SARELA et al., 1992; KAPLAN et al., 2001; PATUREL et al., 2004). A. actinomycetemcomitans juntamente com Haemophilus influenzae, Haemophilus parainfluenzae, Aggregatibacter aphrophilus, Aggregatibacter paraphrophilus, Cardiobacterium hominis, Eikenella corrodens e Kingella kingae, compõem o grupo HACEK, envolvido com a endocardite em humanos (PATUREL et al., 2004; FINE et al., 2006; NORSKOV-LAURITSEN e KILIAN, 2006), sendo que, dentro deste grupo, A. actinomycetemcomitans é o mais prevalente nos casos de endocardite (PATUREL et al., 2004). 
Os fatores de virulência produzidos por A. actinomycetemcomitans favorecem a colonização da bactéria aos tecidos do hospedeiro. Dentre estes fatores, destacam-se mecanismos de adesão e invasão aos tecidos do hospedeiro, liberação de toxinas como a leucotoxina e a toxina distensora citoletal, produção de catalase e proteínas de superfície ligantes ao ferro (WILSON e HENDERSON, 1995; GRABER et al., 1998; MAYER et al., 1999; KOMATSUZAWA et al., 1999; KOMATSUZAWA et al., 2002; MIYAZAKI et al., 1984; KACHLANY et al., 2000; NALBANT et al., 2003; ROSE et al., 2003; MINTZ et al., 2004; OUHARA et al., 2006).

A. actinomycetemcomitans também é capaz de formar biofilmes sobre superfícies abióticas como vidros, plásticos e hidroxiapatita, constituindo-se em importante fator na colonização da cavidade oral e desencadeamento da doença (KAPLAN, 2003). O principal componente da matriz do biofilme formado por esta espécie é o poli-N-acetil-glicosamina (PGA), codificado pelo lócus pga ABCD. O PGA promove adesão intercelular, constitui barreira física e mecânica, e confere à bactéria maior resistência a antibióticos (KAPLAN et al., 2004). Isolados clínicos de A. actinomycetemcomitans, apresentam capacidade de formar biofilmes densos sobre superfícies abióticas in vitro, resistentes à remoção por agentes como detergentes, proteases, aquecimento e sonicação leve (FINE et al., 1999). Por outro lado, $A$. actinomycetemcomitans também pode sintetizar uma hidrolase solúvel que degrada o PGA, denominada dispersina B (Dsp B). A dispersina B apresenta grande potencial biotecnológico, pois além de promover a dispersão do biofilme de A. actinomycetemcomitans, esta provoca a desagregação e dispersão do biofilme produzido por diversas outras bactérias Gram positivas e negativas (RAMASUBBU et al., 2005).

Em A. actinomycetemcomitans, a aderência não específica e autoagregação relacionam-se com a presença de fímbrias (KACHLANY et al., 2000). O lócus de aderência "tight" (tad) de $A$. actinomycetemcomitans está associado à formação e maturação da fímbria FLP, requerida para formação de biofilmes densos (PEREZ et al., 2006). É composto por 14 genes dispostos em um operon: flp1-flp2-tadV-rcpCAB-tadZABCDEFG (Figura1) (KACHLANY et al. 2000; TOMICH; FINE; FIGURSKI, 2006). O gene flpl codifica a proteína pré-FLP1, principal componente estrutural da fimbria FLP, que após modificações proteolíticas promovidas por outros genes do operon tad, forma o pili FLP funcional (HAASE; ZMUDA; SCANNAPIECO, 1999; 
KACHLANY et al., 2001; TOMICH; FINE; FIGURSKI, 2006, KAPLAN et al., 2002; PEREZ et al., 2006). O segundo gene do operon, flp2, codifica possivelmente a subunidade secundária da fímbria (PEREZ et al., 2006) apresentando 50\% de similaridade com a proteína Flp1 (KACHLANY et al., 2001). O produto do gene tadV é uma peptidase pré-pilina do sistema Tad de A. actinomycetemcomitans com secreção tipo II, homólogo à proteína $c p A$ de Caulobacter crescentus (SKERKER et al., 2000), requerido para a formação e maturação do pili Flp1 (TOMICH; FINE; FIGURSKI, 2006).

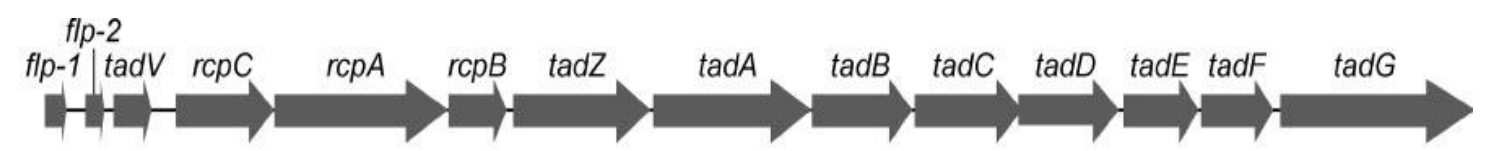

Figura 1- Lócus tad de A. actinomycetemcomitans FONTE: Adaptado de Tomich, Fine e Figurski (2006).

A expressão das fímbrias pelas células de A. actinomycetemcomitans exibe fases de transição que podem ser influenciadas por fatores ambientais como $\mathrm{pH}$, temperatura, oxigênio e concentração de ferro (SCANNAPIECO et al., 1987). Esta fase de transição na expressão da fímbria se reflete na capacidade de A. actinomycetemcomitans formar duas variantes morfológicas de colônias, in vitro (HAASE; ZMUDA; SCANNAPIECO, 1999): colônias com fenótipo rugoso, caracterizadas por serem translúcidas $(\sim 1 \mathrm{~mm})$ com bordas irregulares e superfície aderente; e colônias com fenótipo liso caracterizadas por serem maiores, com bordas regulares, centro com forma de estrela e mais opacas obtidas após repetidas passagens em meio de cultura. Isolados clínicos de morfologia colonial rugosa aderem firmemente às superficies com formação de biofilmes densos enquanto a variante lisa não expressa fímbria e apresenta capacidade de autoagregação reduzida (FINE et al., 1999). A transição do fenótipo rugoso para liso pode estar associada a um evento mutacional com deleção ou substituição de um nucleotídeo na região -35 ou -10 do promotor flp (KARCHED; SATYASEELA; AISIKAINEN, 2007; WANG; LIU; CHEN, 2005).

Dois outros genes, $r c p A$ e $r c p B$, que compõem o lócus $t a d$, codificam as proteínas de membrana externa RcpA e RcpB respectivamente, expressas exclusivamente nas variantes rugosas e envolvidas na adesão inicial, colonização às superfícies mucosas e adesão à hidroxiapatita recoberta por saliva (HAASE; ZMUDA; SCANNAPIECO, 1999). À jusante dos 
genes $r c p$, encontramos o gene $t a d A$, cuja proteína codificada é homóloga à secreção de NTPases da secreção tipo IV (TOMICH; FINE; FIGURSKI, 2006). Mutantes deficientes nos genes tadA e flpl mostraram capacidade reduzida de colonização na cavidade oral de ratos (SHEINE et al., 2003).

A adesão de A. actinomycetemcomitans ao tecido epitelial é mediada por macromoléculas como adesinas fimbriais e não fimbriais (MINTZ e FIVES-TAYLOR, 1994), e receptores específicos na superfície da célula hospedeira, como transferrinas e integrinas (HENDERSON et al., 2003). A ligação de A. actinomycetemcomitans ao receptor da célula hospedeira provoca um evento de sinalização, levando à formação de microvilosidades devido ao rearranjo do citoesqueleto da célula hospedeira, resultando na internalização da bactéria via vacúolo endocítico. As variantes lisas expressam proteínas associadas à maior eficiência de invasão às células epiteliais do que as rugosas (HAASE; STREAM; SCANNAPIECO, 2003). $A$. actinomycetemcomitans apresenta recursos que possibilitam escapar do vacúolo através da liberação da enzima fosfolipase C (HENDERSON et al., 2003) e uma vez livre no citoplasma, $A$. actinomycetemcomitans estimula a regulação de uma série de genes que facilitam sua adaptação ao ambiente intracelular, permitindo desta maneira, a sua multiplicação e difusão intra e intercelularmente (HANDFIELD et al., 2005)

O envolvimento de genes de A.actinomycetemcomitans que participam no processo de adesão e invasão às células epiteliais não foi completamente elucidado. Entre as adesinas nãofimbriais, as proteínas do envelope externo de bactérias (OMPs) que foram altamente conservadas ao longo da evolução, exercem funções como adesinas, invasinas, além de outras funções como receptores para bacteriófagos, atividade de porinas, mediadores da conjugação, fator de resistência ao soro, além de conferirem estabilidade à membrana externa (ASAKAWA et al., 2003). Diferentes OMPs de A. actinomycetemcomitans revelaram similaridade a fatores de virulência encontrados em outros microrganismos patogênicos. O soro de pacientes com periodontite relacionada a A. actinomycetemcomitans apresentou anticorpos específicos contra as seis maiores proteínas de membrana externa: OMP100, OMP64, OMP39, OMP29, OMP16 e OMP18 (KOMATSUZAWA et al., 1999). A OMP100, uma proteína de 100kDa, também conhecida como ApiA, contribui na adesão e invasão de A. actinomycetemcomitans em células de carcinoma oral (KB) (ASAKAWA et al., 2003), além de conferir ligação à fibronectina e ao 
colágeno (YUE et al., 2007). A OMP29, pertencente à família OmpA, é uma proteína termomodificável, que representa o principal alvo de imunoglobulinas G ( $\operatorname{IgG}$ ) no soro de pacientes com periodontite colonizados por A. actinomycetemcomitans (WILSON, 1991a e b). As OmpA representam a principal proteína do envelope externo de muitos patógenos Gram negativos, e relacionam-se à capacidade de invasão em células não fagocíticas. É interessante observar que a resposta contra OMP100 e OMP29 pode ser observada na maioria dos casos de periodontite agressiva, mas muitos pacientes que apresentam anticorpos séricos contra LPS de $A$. actinomycetemcomitans são soronegativos para estas OMPs (BRUNHEIRA, 2006), sugerindo expressão diferencial de OMP29 entre as amostras. Estudo recente em nosso laboratório mostrou que a expressão do gene omp29 é dependente da fase da cultura bacteriana, indicando regulação da expressão deste fator de virulência por condições ambientais (LONGO, 2008).

Outras proteínas de membrana externa, consideradas adesinas foram relatadas em $A$. actinomycetemcomitans. A proteína autotransportada Aae (sistema de transporte do tipo V), também está envolvida com a adesão (ROSE; MEYER; FIVES-TAYLOR, 2003; FINE et al., 2006). Uma mutante de A. actinomycetemcomitans deficiente em aae mostrou reduzida ligação às células epiteliais (ROSE; MEYER; FIVES-TAYLOR, 2003). A interação entre a dupla mutante A. actinomycetemcomitans aae- apia-, (que codifica a OMP100) e célula epitelial humana confirmou que Aae e ApiA são requeridos para conferir uma ligação eficiente, porém estas adesinas não foram relevantes na interação com células epiteliais bovinas ou de ratos (YUE et al., 2007).

$\mathrm{O}$ gene emaA, homólogo às proteínas ligantes de colágeno YadA de Yersinia enterocolitica, codifica um mediador direto de adesão ao colágeno (MINTZ et al., 2004), mas esta interação não é exclusiva desta adesina, pois os produtos dos genes apiA e apiBC também participam na interação de A. actinomycetemcomitans a proteínas da matriz extracelular, incluindo vários tipos de colágeno, fibronectina, laminina e glicosaminoglicanas (LI et al., 2004).

Pouco se conhece sobre os genes associados à capacidade de invasão de $A$. actinomycetemcomitans em células não fagocíticas. Foi sugerido que o gene apaH de $A$. actinomycetemcomitans, homólogo a ialA, ygd, e invA, associados com a invasão de Bartonella bacilliformis (MITCHELL e MINNICK, 1995), Escherichia coli K1 (BESSMAN et al., 2001) e Rickettsia prowazekii (GAYWEE et al., 2002) respectivamente, relaciona-se com a capacidade 
invasiva também em A. actinomycetemcomitans. Mutantes defectivas em apaH perderam a capacidade invasiva, enquanto a presença de um plasmídio recombinante codificando $A$. actinomycetemcomitans apaH conferiu invasividade a E. coli (SAARELA et al., 1999). Este gene codifica uma diadenosina hidrolase que cliva uma "alarmôna" diadenosina tetrafosfato (Ap4A), uma classe de nucleotídeos sinalizadores do tempo de divisão celular (ROSE et al., 2003; SAARELA et al., 1999). As cepas de A. actinomycetemcomitans podem ser divididas em cinco grupos com relação ao gene apaH (DOGAN et al., 1999), e a maioria das amostras apresenta ApaH contendo a seqüência de aminoácidos RGD que reconhece receptores integrina na superfície de células eucariontes (SAARELA et al., 1998; PAJU et al., 1998; PINHEIRO et al., 2010).

A invasão de A. actinomycetemcomitans em célula epitelial requer também a expressão de proteínas relacionadas à adaptação intracelular e homeostase. As proteínas codificadas pela orf 859 e vapA foram associadas à adaptação intracelular. Mutantes defectivos em orf859 apresentaram deficiência na sobrevivência intracelular enquanto o produto do gene vapA, foi relacionado ao aumento da capacidade invasiva. No entanto, o produto destes genes ainda não tem um papel definido na virulência de A. actinomycetemcomitans (HANDFIELD et al., 2005; CAO et al., 2004).

A. actinomycetemcomitans apresenta também a capacidade de expressar duas toxinas com propriedades citolíticas contra as células humanas, a toxina distensora citoletal e a leucotoxina. A toxina distensora citoletal (CDT) é uma holotoxina constituída por três subunidades CdtA, CdtB e CdtC (NALBANT et al., 2003), codificados pelos genes $c d t A, c d t B$ e $c d t C$ (MAYER et al, 1999). Esta toxina é associada a indução da proteína p21 ${ }^{\mathrm{CIP} 1 / \mathrm{WAF1}}$ (regulador negativo de quinases ciclinas dependentes-cdk) levando à parada do ciclo celular na fase G2 em diferentes células alvo humanas (SATO et al., 2002), indução de apoptose relacionada à expressão da proteína p53 (SATO et al., 2002; HANDFIELD et al., 2005; AMARAL et al., 2010), imunossupressão de linfócitos T (MAYER et al., 1999; SHENKER et al., 1999; SUGAI et al., 1998), estimulação da secreção de citocinas (AKIFUSA et al., 2005), e inibição da produção de NO por macrófagos ativados (FERNANDES et al., 2008). CdtB representa a subunidade tóxica que exibe atividade de fosfatase e desoxirribonuclease 1 , enquanto as subunidades CdtA e CdtC promovem a ligação e transporte de CdtB à célula hospedeira (SMITH 
et al., 2006). Além disso, CDT também está envolvida no processo de reabsorção óssea, através da indução da expressão de RANKL por células do tecido periodontal, induzindo assim, a ativação e diferenciação de osteoclastos (BELIBASAKIS et al., 2005; BELIBASAKIS et al., 2005b).

Um estudo recente sobre avaliação de títulos de imunoglobulinas G para cada subunidade CDT demonstrou que as frações CDT são pouco imunogênicas, embora tenha sido demonstrado que a resposta a $\mathrm{CdtC}$ ocorre apenas no soro de pacientes com periodontite agressiva generalizada, mas não localizada, enquanto a resposta às demais frações não se relacionou com a condição periodontal (ANDO et al., 2010).

A outra toxina secretada por A. actinomycetemcomitans é a leucotoxina, codificada em um operon composto por quatro genes, $\operatorname{lt} x C, \operatorname{lt} x A$, $\operatorname{lt} x B$, ltxD, capaz de provocar a morte de leucócitos polimorfonucleares humanos, macrófagos (KOLODRUBETZ et al., 1989) e células HL-60 promielocíticas (NALBANT et al., 2003) por apoptose. A leucotoxina é expressa de maneira diferencial entre as amostras de A. actinomycetemcomitans (LALLY et al., 1989), sendo que as amostras produtoras de altos níveis da toxina apresentam deleção de 530pb na região promotora do operon ltx, resultando num aumento da transcrição da leucotoxina. Em estudo longitudinal com 24 crianças de famílias com histórico de periodontite agressiva, foi demonstrado que as crianças que abrigavam o genótipo de A actinomycetemcomitans associado à maior produção de leucotoxina (JP2-like) apresentavam maior possibilidade de conversão de saúde para doença agressiva do que as demais (BUENO; MAYER; DI RIENZO, 1998). Foi descrito também maior expressão da leucotoxina de A. actinomycetemcomitans em uma cepa causada pela inserção de IS 1301, rompendo a regulação normal do operon ltx (MITCHELL; GAO; DEMUTH, 2003).

$\mathrm{O}$ envolvimento dos genes $c d t$ e ltx de A. actinomycetemcomitans na capacidade de induzir apoptose em células $\mathrm{T}$, foi demonstrado em estudos com mutantes isogênicos em ltxA ou em cada gene $c d t$. No entanto, outras moléculas com função citolítica além de CDT ou LTX, como as proteínas Groel-like também participam do processo apoptótico (NALBANT et al., 2003). 
A expressão de genes de virulência por bactérias patogênicas é geralmente modulada em resposta a mudanças ambientais encontradas no sítio de infecção. A análise de fatores associados à virulência de um dado patógeno apenas em condições de laboratório, poderia implicar na ausência de expressão de muitos destes fatores durante o crescimento in vitro (HANDFIELD et al., 2000). Assim, no presente estudo, nos propomos a analisar a transcrição de fatores associados a virulência da bactéria após a sua interação com células epiteliais gengivais.

Não somente a expressão dos genes de A. actinomycetemcomitans poderia ser alterada durante a infecção, como também a expressão de uma série de genes das células eucarióticas pode ser induzida.

A manutenção do organismo livre de patógenos invadindo os tecidos requer a cooperação entre o sistema immune inato e adaptativo. A interação da bactéria com células epiteliais desencadeia as primeiras reações do hospedeiro frente aos microrganismos. A resposta inicial à infecção é responsabilidade do sistema imune inato, que reconhece os padrões moleculares associados a patógenos (PAMPs) por diferentes receptores de reconhecimento de padrões (PRRs), resultando na ativação de uma série de vias de sinalização. Entre os PRRs incluem-se os receptores Toll - like (TLRs), receptores com domínio de ligação de nucleotídeos e oligomerização (NOD)-like (NLRs) e outros (FRANCHI et al., 2009). Os receptores Toll-like são proteínas transmembrana, enquanto os receptores NOD são sensores citosólicos intracelulares, descritos inicialmente como "receptores Toll-like intracelulares" que reconhecem PAMPs associados a patógenos intracelulares (INOHARA et al., 1999; KIRKWOOD et al., 2009; FRANCHI et al., 2009).

A ligação dos PAMPS aos TLRs é suficiente para a transcrição, síntese e secreção de citocinas como IL-8, IFN- $\gamma$ e IL-12 (JANEWAY e MEDZHITOV, 2002; TAKEDA; KAISHO; AKIRA, 2003), mas não de citocinas como IL-1 $\beta$ e IL-18, cuja produção e secreção são extremamente controladas, requerendo um segundo sinal distinto (ABDUL SATER et al., 2009). Neste último caso, a ligação de um PAMP como o lipopolissacarídeo (LPS) ou a flagelina, estimula o TLR expresso na superfície celular e promove a produção e o acúmulo intracelular destas citocinas imaturas. Um segundo sinal, usualmente derivado de sinais de perigo (DSs), produzido pela célula infectada, morrendo ou sob condição de estresse, conhecido como padrões moleculares associados a dano (DAMPs), é reconhecido pelas células vizinhas. O DS liga-se ao 
receptor de sinal de perigo (DSR) estimulando a formação de um inflamassoma que ativa a protease caspase-1 e resulta no processamento e na secreção das citocinas (BRODSKY e MONAK, 2009; ABDUL-SATER et al., 2009).

Os patógenos que ganham acesso ao compartimento celular, como no citosol, são reconhecidos pelos receptores NOD. A infecção de células epiteliais por bactérias invasivas, como Shigella flexneri invasiva provoca indução da oligomerização de NOD1, levando à ativação da via NFkB (CHAMAILLARD et al., 2003).

A transdução de sinais é um processo complexo em que a célula converte os sinais ambientais em uma série de reações bioquímicas intracelulares (PENG et al., 2010). Assim, após a sinalização provocada por diferentes estímulos, ocorre a ativação de vias de sinalização, e a ativação da mesma via pode ter consequiências distintas, na dependência do estímulo inicial. Além disso, cada tipo de célula parece predisposta a responder a ativação de uma via particular de sinalização com uma conseqüência distinta (IQBAL et al., 2010).

A via da proteínas quinase mitógeno ativadas (MAPK) é considerada elemento chave na detecção e transmissão da resposta celular pela ação sequencial de eventos de fosforilação frente às condições ambientais. Esta via constitui uma grande rede de quinases intracelulares que regula diversos processos fisiológicos, como crescimento celular, diferenciação e morte celular por apoptose (JUNTILLA; LI; WESTERMACK, 2008). As MAPKs são famílias de proteínas cuja atividade é regulada pela fosforilação de resíduos treonina $(\mathrm{T})$ e tirosina $(\mathrm{Y})$ conservados. A estimulação por fatores de crescimento, citocinas inflamatórias ou estresse físicos, leva à ativação de MAPKs. A cascata de sinalização MAPK é modulada por três eventos subsequentes de fosforilação (PIMIENTA e PASCUAL, 2007) (Figura 2). Isto significa que cada MAPK é fosforilada por MKKs (Serina/Treonina (S/T) e Tirosina (Y)), que por sua vez é ativada por S/T MKKK quinases (JUNTILLA; LI; WESTERMACK, 2008).

Três vias de MAPKs têm sido caracterizadas em detalhe (Figura 2): quinase 1,2 regulada extracelularmente (ERK1,2), quinase c-JUN $\mathrm{NH}_{2}$-terminal (JNK) e p38. A via ERK é ativada por uma variedade de mitógenos e forbol éster, enquanto a via c-JUN $\mathrm{NH}_{2}$-terminal quinase $(\mathrm{JNK})$ /proteína quinase stress ativada (SAPK) e a via p38 são estimuladas principalmente por stress ambiental e citocinas inflamatórias. Após a ativação das MAPKs (ERK 1,2, JNK 1-3 e p38 $\alpha, \beta, \gamma, \hat{\emptyset})$ no citoplasma ou núcleo, estas regulam a transcrição gênica, modulando a função do fator de transcrição alvo através da fosforilação serina/treonina $(\mathrm{S} / \mathrm{T})$. Em adição ao efeito 
transcricional da sinalização das MAPKs, evidências apontam que MAPKs regulam o comportamento celular, fosforilando proteínas citoplasmáticas alvo, como as proteínas apoptóticas (ex. famílias BH3) ou proteínas do citoesqueleto (JUNTILLA; LI; WESTERMACK, 2008).

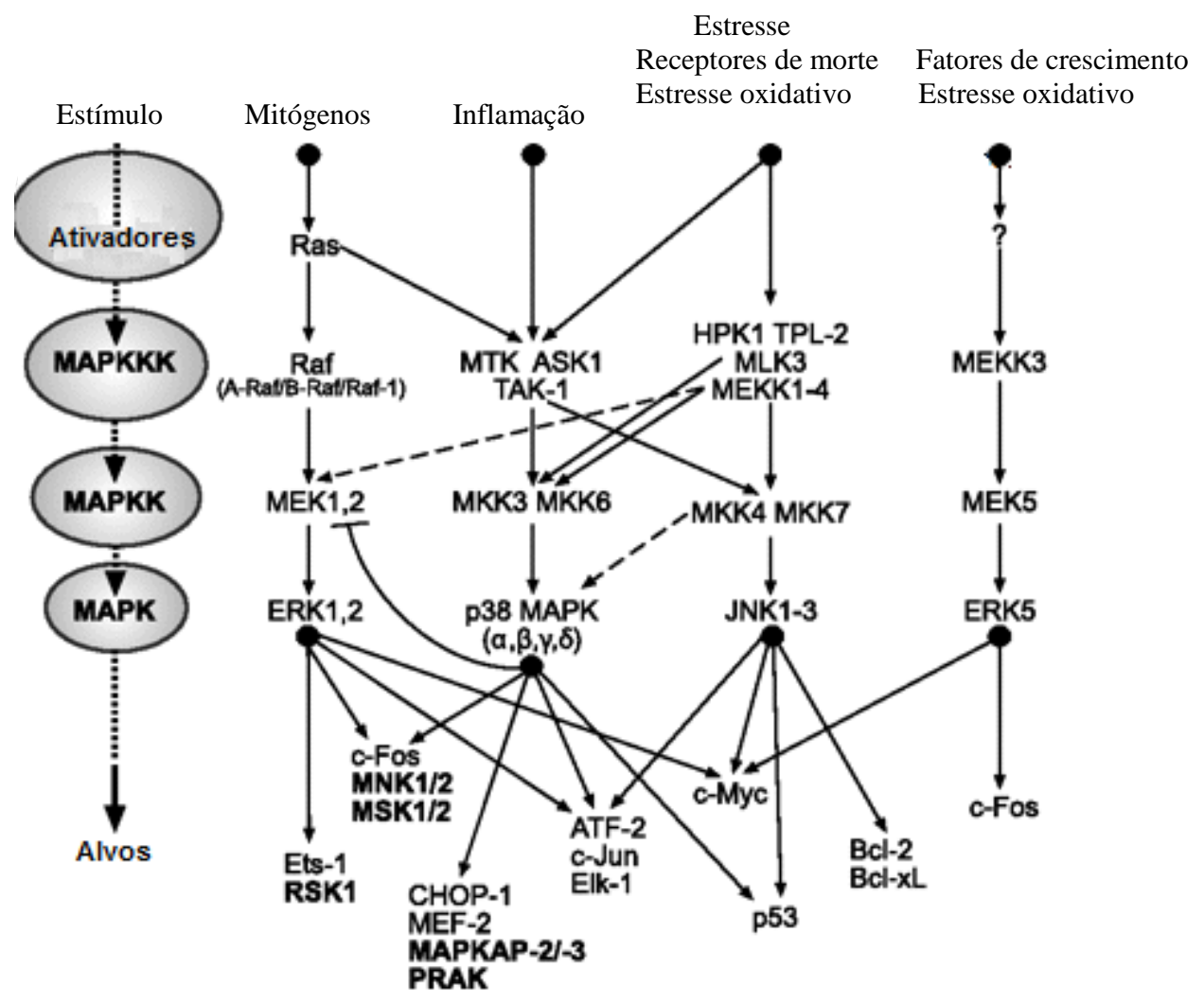

Figura 2- Vias de sinalização MAPK. As vias de sinalização MAPK estão organizadas em módulos de cascatas em que a ativação por receptores da superfície celular das quinases antecedentes levam à ativação sequencial de um módulo MAPK (MAPKKK $\rightarrow$ MAPKK $\rightarrow$ MAPK). O esquema ilustra os componentes da via principal MAPK e exemplos das proteínas alvo da via MAPK. As quinases alvo estão em negrito. As linhas indicam as conexões de sinalização contextodependente entre os módulos MAPK.

Fonte: Adaptado de Juntilla, Li e Westermack (2008)

A via p38 MAPK (MAPKKKs/MKK3,4,6/p38 $, \beta, \gamma, \measuredangle)$ pode ser ativada em resposta a citocinas inflamatórias, assim como a patógenos e estresse ambiental (estresse osmótico, luz ultravioleta, choque térmico e hipóxia). Esta via também pode ser ativada por alguns mitógenos, incluindo eritropoetina, fator 1 de estimulação de colônias (M-CSF) e fator 2 de estimulação de 
granulócitos e macrófagos (GM-CSF) (JUNTILLA; LI; WESTERMACK, 2008). Considerando a diversidade de sinais que ativa a via p38 MAPK, não é surpresa que diversos MAPKKKs possam iniciar o módulo de sinalização p38 MAPK e que a especificidade de ativação pode ser

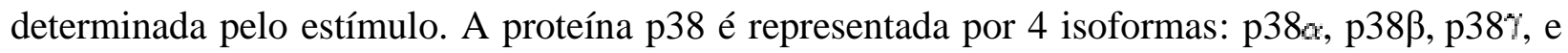
p38סீ. A ativação de todas as isoformas de p38 é alcançada pela dupla fosforilação de uma treonina e uma tirosina dentro da sequência treonina-glicina-tirosina (TGY) no domínio de ativação da quinase (JUNTILLA; LI; WESTERMACK, 2008). A proteína p38 fosforilada pode ativar vários fatores de transcrição, incluindo ATF-2, CHOP-1, MEF-2, p53, e Elk-1. Além disso, p38 pode ativar outras quinases, como MNK1 and MNK2, MSK1, PRAK, MAPKAPK-2, and MAPKAPK-3. Entre as isoformas, a proteína p38 $\alpha$ tem sido alvo de mais estudos e é provavelmente a mais relevante na resposta inflamatória (MUTHUSAMY e PIVA, 2010). A ativação da via p38 MAPK é requerida para indução de apoptose em diferentes células, parada do ciclo celular na fase G2/M e regulação do ciclo celular através da modulação das proteínas p53 e p73. A via p38 apresenta ainda, outras importantes funções, como regulação de moléculas inflamatórias, diferenciação de queratinócitos, células epidermais, mioblastos e células do sistema imune, assim como media a resposta imune inata (JUNTILLA; LI; WESTERMACK, 2008). Além disso, a ativação da via p38 MAPK também está associada ao início da doença periodontal (KIRKWOOD e ROSSA, 2009).

A via JNK (quinase c-JUN N-terminal) é ativada principalmente por estresse celular e citocinas (JUNTILLA; LI; WESTERMACK, 2008). As quinases JUN N-terminal apresentam-se em três isoformas: JNK1, JNK2 e JNK3. As JNKs são ativadas por MKK4 e MKK7. Estas MAPKKs são ativadas por MAPKK-quinases (MAPKKK) como MEK1, MEKK2, e por uma variedade de outros estímulos dependendo do tipo celular (MUTHUSAMY e PIVA, 2010). A via JNK pode mediar apoptose, proliferação, ou sobrevivência, dependendo do estímulo e condições celulares (JUNTILLA; LI; WESTERMACK, 2008). O mais clássico substrato de JNK é o fator de transcrição c-Jun, do qual o nome JNK é derivado. JNK pode ativar outros fatores de transcrição, como ATF-2, Elk-1, MEF-2c, p53, and c-Myc. JNK também apresenta outros substratos transcricionais, como as proteínas antiapoptóticas Bcl2 e Bcl-xL (JUNTILLA; LI; WESTERMACK, 2008).

A via ERK (A-Raf, B-Raf, Raf-1 $\rightarrow$ MEK1,2 $\rightarrow$ ERK1,2) é ativada principalmente em resposta a mitógenos e fatores de crescimento. Muitos dos sinais ativadores da via ERK são 
iniciados através da ativação de pequenas proteínas $G$, Ras, proteínas ligadas à membrana ativadas através da troca de ligação GDP para GTP. Esta via têm sido associada com crescimento celular, proliferação celular e sobrevivência (JUNTILLA; LI; WESTERMACK, 2008). As proteínas quinases reguladas por sinais extracelulares (ERK) apresentam-se em diferentes isoformas: ERK1/2, ERK3/4, ERK5 e ERK7/8. Entre as isoformas identificadas, a ERK1/2 é a melhor caracterizada, e envolve vários estímulos e receptores que ativam MAPKKK (Raf-1, BRaf, A-Raf). O MAPKKK ativado desencadeia a fosforilação de MEK1 e MEK2 (MAPKK), que por sua vez, fosforila ERK1/2. O ERK1/2 fosforilado ativa os alvos subsequentes como Elk1, c-Fos e c-Myc (MUTHUSAMY e PIVA, 2010). A sinalização mediada por ERK1/2 tem o papel fundamental na proliferação celular e sobrevivência (JUNTILLA; LI; WESTERMACK, 2008).

Sinais inflamatórios, estresse metabólico e dano ao DNA ativam também a via NFkB, fundamental na regulação da inflamação, resposta imune inata e adaptativa, desenvolvimento, sobrevivência e proliferação celular (O’DEA e HOFFMANN, 2009). A família de fatores de transcrição NFkB forma complexos diméricos com famílias das proteínas Rel, que consistem em cinco membros: p65 (RelA), RelB, c-Rel, p50/p105 (NFkB1) e p52/p100 (NFkB2). O complexo inativo NFkB/Rel está localizado no citoplasma ligado a proteínas inibitórias kB (IkB). Para que ocorra a ativação do complexo NFkB/Rel, a proteína IkB necessita ser fosforilada por quinases IkB (IKK) que são por sua vez, ativados por citocinas, fatores de crescimento, receptores de antígenos, MAPKKKs e outras quinases. Uma vez que o complexo NFkB/Rel esteja livre de proteínas IkB, este pode translocar-se para o núcleo e assim induzir a transcrição dos genes alvos, sendo este processo conhecido como via canônica. O complexo NFkB/Rel pode também sinalizar através de uma via não canônica (MUTHUSAMY e PIVA, 2010). Enquanto a ativação da via p38 MAPK foi associada ao início da doença periodontal (KIRKWOOD e ROSSA, 2009), a ativação da via do NFkB foi associada ao aumento da severidade da doença periodontal (AMBILI et al., 2005).

Portanto, o epitélio gengival não representa apenas uma barreira física contra a invasão de patógenos, mas também pode atuar como sensor em resposta à presença das bactérias através dos receptores de reconhecimento de patógenos (PPR), como os receptores Toll-like (TLRs) e receptores NOD (NLRs) (JANEWAY e MEDZHITOV, 2002; INOHARA et al., 1999). Além disso, pelo menos um dos receptores de sinal de perigo, o receptor purinérgico para ATP 
extracelular (P2X7) também é expresso e funcional em células epiteliais gengivais (YILMAZ et al., 2010). Foi também demonstrado que as células do epitélio gengival, bem como outras células do epitélio oral expressam inflamassoma Nalp3, que quando ativado resulta na secreção de IL-1 $\beta$ (YILMAZ et al, 2010). As células epiteliais gengivais (GEC) mostram-se assim, fundamentais na resposta inata do hospedeiro frente às bactérias periodontais (DARVEAU; TANNER; PAGE, 1997; ESKAN et al., 2008; HASEGAWA et al., 2008; YILMAZ et al., 2010).

A maioria dos estudos sobre a resposta imune inata contra infecções bacterianas têm-se centrado em células do sistema imune de origem hematopoiética, mas as células epiteliais infectadas por A.actinomycetemcomitans e Porphyromonas gingivalis e outras bactérias orais também podem induzir a produção de citocinas pró-inflamatórias, quimiocinas, defensinas e moléculas de adesão intercelular (DARVEAU; TANNER; PAGE, 1997; KRISANAPRAKORNKIT et al., 2000; SANDRO et al., 2000; ASAI et al., 2001; SCANNAPIECO; WANG; SHIAU, 2001, HUANG et al., 2004; KUSUMOTO et al., 2004; EICK et al., 2006; HASEGAWA et al., 2008; SHIMADA et al., 2008; ESKAN et al., 2008).

Estudos prévios demonstraram que o contato de células epiteliais com produtos de $A$. actinomycetemcomitans é capaz de modular a expressão gênica da célula epitelial. Por exemplo, os níveis de prostaglandina-2 (PGE2), importante mediador da resposta inflamatória e de cicloxigenase-2, foram estimulados pelo contato de A. actinomycetemcomitans com células epiteliais gengivais (HGEC) (NOGUSHI et al., 2003).

Proteínas de membrana externa de A. actinomycetemcomitans, como OMP100, induzem a secreção de citocinas inflamatórias e peptídeos antimicrobianos em células epitelias gengivais. A OMP100 de A. actinomycetemcomitans é capaz de ligar-se à fibronectina e esta interação induz a síntese de $\beta$-defensina2 humana (hBD2) via MAP kinase, embora a estimulação secundária por citocinas inflamatórias induzidas pela exposição bacteriana possivelmente colabora no processo (OUHARA et al., 2006).

A interação entre células epiteliais e microrganismos é o passo inicial da infecção bacteriana no periodonto. Assim, o conhecimento dos mecanismos induzidos em cada etapa da interação entre bactéria e células epiteliais poderia corroborar para o entendimento da patogenia, bem como fornecer bases científicas para o desenvolvimento de estratégias que dificultem a colonização pelo patógeno. 
Grande parte das pesquisas atualmente tem contribuído na elucidação dos mecanismos pelos quais as células de organismos multicelulares e unicelulares "sentem" o ambiente e traduzem estas observações em informação útil (IQBAL et al., 2010). A. actinomycetemcomitans é um importante patógeno periodontal, apresentando vários fatores que o tornam potencialmente virulento. Estudos vêm demonstrando a relação entre a detecção de bactérias periodontopatogênicas e a presença de altas concentrações de metaloproteinases e citocinas próinflamatórias no fluido gengival de sítios que apresentam progressão da periodontite quando comparados aos sítios inativos (SILVA et al., 2008). Assim, sendo a adesão e invasão, recursos estratégicos utilizados por A. actinomycetemcomitans para desencadear a patogenia, é evidente a importância da identificação dos genes expressos neste processo.

Baseados no exposto, consideramos que o estudo de genes ativados pelo contato da bactéria com as células epiteliais poderia elucidar os mecanismos envolvidos na adaptação do microrganismo para interagir com essa primeira barreira do hospedeiro, propiciando a sua colonização. Além disso, a análise do perfil de transcrição de genes associados à via de transdução de sinais da célula epitelial após a infecção com A.actinomycetemcomitans permitiria a identificação dos eventos moleculares iniciais promovidos pela presença do patógeno que provocam um desequilíbrio na homeostase do microambiente periodontal, levando ao quadro de destruição tecidual encontrado na periodontite. 


\section{OBJETIVOS}

Visando contribuir com o conhecimento sobre o processo de interação entre células epiteliais e Aggregatibacter actinomycetemcomitans, os objetivos do presente estudo foram:

- analisar o perfil de transcrição de genes relacionados a fatores de virulência de $A$. actinomycetemcomitans após a interação da bactéria com células epiteliais gengivais OBA-9.

- analisar o perfil de transcrição de genes relacionados à transdução de sinais pelas células epiteliais gengivais OBA-9 após infecção com A. actinomycetemcomitans.

A expressão de genes regulados positivamente nas células epiteliais após contato com a bactéria foi confirmada pela determinação da concentração dos produtos destes genes por ELISA no sobrenadante de culturas celulares infectadas.

Para determinar se esta expressão ocorreria in vivo nos tecidos peridontais afetados, os produtos dos genes regulados positivamente por células epiteliais infectadas in vitro foram determinados também em tecido gengival obtido de pacientes com diferentes condições periodontais. 


\section{MATERIAL E MÉTODOS}

\subsection{Cepas bacterianas}

Para análise da expressão gênica de A.actinomycetemcomtians, foram analisadas as cepas de referência A. actinomycetemcomitans ATCC29523 (ZAMBON et al., 1983; KAPLAN et al., 2002), JP2 (ZAMBON et al., 1996, KAPLAN et al., 2002) e SUNY 465 (ZAMBON et al., 1985), apresentadas na tabela 1. Para o estudo da expressão gênica da célula epitelial foi selecionada a amostra JP2. As cepas foram obtidas de estoques do laboratório de Microbiologia Oral, mantidos em leite desnatado (10\%, Skim Milk, Difco, Sparks, MD, EUA), em freezer a $80{ }^{\circ} \mathrm{C}$ (Revco Scientific, Waltham, MA, EUA).

Tabela 1- Relação das cepas padrão utilizadas para os ensaios de expressão gênica bacteriana

CEPAS

ATCC 29523

JP2

SUNY 465
Cepa isolada de sangue, Hospital de Denver, EUA, sorotipo a. (ZAMBON et al., 1983). Produtora de baixos níveis de leucotoxina, cdt tipo 2 (KAPLAN et al., 2002).

Cepa isolada de placa subgengival de paciente afro americano com PAL.

Altamente leucotóxica, sorotipo b (ZAMBON, et al., 1996), cdt tipo 2 (KAPLAN et al., 2002)

Cepa sorotipo b (Zambon, 1985), altamente invasiva e minimamente leucotóxica 


\subsection{Condições de cultura bacteriana}

Alíquotas do estoque congelado de cada uma das cepas foram cultivadas na superfície de ágar tripticase soja (Oxoid Ltda, Basingstoke, Hampshire, Inglaterra), acrescido de 0,6\% de extrato de levedura (Oxoid Ltda, Basingstoke, Hampshire, Inglaterra) (ágar TSBYE) e incubadas em estufa em atmosfera de $10 \%$ de $\mathrm{CO}_{2}$ (Shel Lab, Oregon, EUA) por 24 horas a $37{ }^{\circ} \mathrm{C}$. As colônias foram raspadas com alça Drigalski estéril, inoculadas em $8 \mathrm{ml}$ de caldo TSBYE (Oxoid Ltda, Basingstoke, Hampshire, Inglaterra) em triplicata e incubadas durante 8 horas em estufa com atmosfera de $10 \%$ de $\mathrm{CO}_{2}$. Após este intervalo de tempo, as concentrações das suspensões bacterianas foram ajustadas à $\mathrm{DO}_{495 \mathrm{~nm}} \sim 1,0$ por mensuração em espectrofotômetro (Jenway 6405UV/Vis Essex, Inglaterra), diluídas 1:40 em caldo TSBYE e incubadas por mais 7 horas até alcançarem o meio da fase exponencial. Em seguida, as concentrações das suspensões bacterianas foram ajustadas novamente a DO $495 \mathrm{~nm} \sim 0,2$ correspondendo a $3 \times 10^{8} \mathrm{UFC} / \mathrm{ml}$.

\subsection{Células OBA-9 e condições de cultura}

As células de linhagem epitelial gengival, denominadas células OBA-9, foram gentilmente cedidas pelo Prof. Dr. Shinya Murakami da Universidade de Osaka, Japão.

As células OBA-9 foram mantidas em frascos de cultura de células de $75 \mathrm{~cm}^{2}$ (Corning Incorporated, N.Y., EUA) contendo $20 \mathrm{ml}$ de meio queratinócito livre de soro - KSFM (Invitrogen, Carlsbad, CA, EUA), suplementado com 100U/ml de penicilina (ICN Biomedicals, Aurora, OH, EUA)/estreptomicina $(100 \mu \mathrm{g} / \mathrm{ml})$ (Calbiochem, Darmstadt, Alemanha) (COSTEA et al., 2005) acrescido de insulina, fator de crescimento epidermal (EGF) e fator de crescimento de fibroblastos (FGF), de acordo com as instruções do fabricante (Invitrogen, Carlsbad, CA, EUA) sob incubação em estufa a $37{ }^{\circ} \mathrm{C}$ com atmosfera de $5 \%$ de $\mathrm{CO}_{2}$ (Shel Lab TC 2123, Oregon, EUA). Quando alcançaram a semi confluência, as células OBA-9 foram lavadas 2 vezes com $10 \mathrm{ml}$ de PBS (0,1M; pH=7,4) e adicionados $2 \mathrm{ml}$ de tripsina (Gibco, Grand Island, NY, EUA) seguindo-se incubação por 4 min em estufa de $\mathrm{CO}_{2}$, para obtenção de suspensões celulares. A seguir, foram adicionados $2 \mathrm{ml}$ de solução de inibidor de tripsina $(10 \mathrm{mg} / \mathrm{ml})$ (Sigma Aldrich, St. Louis, MO, EUA) e as suspensões celulares foram transferidas para um tubo de centrífuga estéril e submetidas a centrifugação a $237 x g$ a $15^{\circ} \mathrm{C}$ durante 5 minutos (Centrífuga 
Eppendorf - Centrifuge 5804R, Hamburg, Alemanha). Após a centrifugação, o sobrenadante foi desprezado e o precipitado ressuspenso em meio queratinócito livre de soro (Invitrogen, Carlsbad, CA). Alíquotas de $10 \mu 1$ desta suspensão de células foram misturadas a $10 \mu 1$ de azul de tripan 0,4\% (Carlo Erba, Rodano, Itália) para a contagem de células viáveis em câmara de Neubauer. A seguir, alíquotas de $1 \mathrm{ml}$ contendo $2 \times 10^{5}$ células $/ \mathrm{ml}$ foram distribuídas nos poços de placas de 24 poços (Corning Incorporated, N.Y., EUA) e incubadas por 24 horas em estufa com atmosfera de 5\% de $\mathrm{CO}_{2}$. Após este período, as células OBA-9 alcançam uma concentração de $3 \times 10^{5}$ células $/ \mathrm{ml}$.

\subsection{Adesão de Aggregatibacter actinomycetemcomitans à célula epitelial}

As culturas bacterianas incubadas até o meio de fase exponencial de crescimento, obtidas como descrito no item 3.2, foram ajustadas a $\mathrm{DO}_{495} \sim 0,2$ e alíquotas de $3 \mathrm{ml}$ foram centrifugadas a $5.200 \mathrm{xg}$ durante $2 \mathrm{~min}$ a $4{ }^{\circ} \mathrm{C}$. O sobrenadante foi desprezado e o precipitado ressuspenso em $50 \mu 1 \mathrm{ml}$ de PBS $(0,1 \mathrm{M} ; \mathrm{pH} 7,4)$ seguindo-se agitação em agitador de tubos por 30 seg. e adição de $950 \mu 1$ de meio queratinócito livre de soro e antibiótico - KSFM. Monocamadas de células epiteliais OBA-9 em poços de placas de 24 poços, contendo $\sim 3 \times 10^{5}$ células/poço, obtidas como descrito no item 3.3 , foram lavadas 3 vezes com PBS $(0,1 \mathrm{M} ; \mathrm{pH}=$ 7,4). As suspensões bacterianas foram adicionadas às monocamadas de células OBA-09, obtendo-se uma MOI (multiplicidade da infecção) de 1:3.000 (célula epitelial/célula bacteriana) (HANDFIELD et al., 2005; RICHARDSON et al., 2005).

As placas contendo células OBA-9 e suspensões bacterianas foram submetidas à centrifugação a $593 x g$ por 10 minutos a $20^{\circ} \mathrm{C}$, para favorecer a interação célula epitelial-bactéria e incubadas por períodos de duas horas de infecção, em estufa com $10 \%$ de $\mathrm{CO}_{2}$ a $37^{\circ} \mathrm{C}$. Após a incubação, os poços foram lavados por duas vezes com PBS, para remoção das células bacterianas não aderidas.

Para a determinação do número de UFC de A.actinomycetemcomitans aderidas por poço, as células epiteliais foram tripsinizadas pela adição de $1 \mathrm{ml}$ de tripsina, seguindo-se incubação por 4 minutos em estufa. As suspensões celulares foram homogeneizadas com pipeta e diluídas

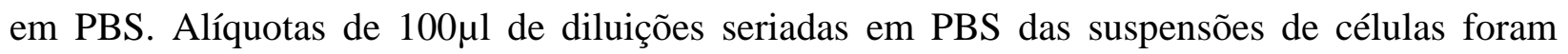


inoculadas em triplicata em placas de ágar TSBYE e incubadas durante 72 horas em estufa com atmosfera de $10 \%$ de $\mathrm{CO}_{2}$ a $37{ }^{\circ} \mathrm{C}$, para posterior contagem de viáveis (UFC), e cálculo do número de UFC de bactérias aderidas/poço. A eficiência de adesão foi calculada conforme a fórmula abaixo, de acordo com Tang et. al. (1993) modificado:

Eficiência de adesão $(\%)=\underline{\text { UFC de A. actinomycetemcomitans aderidas às células epiteliais x } 100}$ $9 \times 10^{8}$ (UFC de A. actinomycetemcomitans adicionadas à monocamada)

Estes procedimentos foram empregados para determinação da transcrição gênica de $A$. actinomycetemcomitans após adesão a células epiteliais por 2 e 24 horas de infecção, seguindose a lavagem das monocamadas para remoção das bactérias não aderidas, a lise das células foi obtida com a adição de Trizol, seguindo-se extração de RNA, como descrito no item 3.5.1.

\subsection{Análise da transcrição gênica bacteriana após adesão a células epiteliais}

A transcrição gênica das amostras ATCC29523, JP2 e SUNY465 foi analisada por reação de transcriptase reversa seguindo-se PCR quantitativo. Foram utilizadas células bacterianas após adesão a células epiteiliais obtidas como descrito no item 3.4 e como controle, as suspensões bacterianas submetidas às memas condições, porém, sem a presença das células epiteliais gingivais OBA-09.

\subsubsection{Extração de RNA}

O RNA foi extraído pela adição de $80 \mu \mathrm{l}$ de Trizol (Invitrogen) em cada um dos 4 poços para cada amostra bacteriana em placa de 24 poços preparadas para os ensaios de adesão e controle sem a adição de células epiteliais (item 3.3). As suspensões de células foram homogeneizadas e transferidas para um tubo de centrífuga estéril, agitadas em Vortex e incubadas por 5 min a $25^{\circ} \mathrm{C}$ para permitir a completa dissociação do complexo nucleoproteico. Para os controles sem a presenca da célula epitelial, as suspensoes bacterianas foram coletadas apos incubacão por 2 horas nas mesmas condições e centrifugadas $5.200 x g$ durante 4 min a $4{ }^{\circ} \mathrm{C}$ 
. Em seguida, o sobrenadante foi descartado e o precipitado ressuspenso em $320 \mu 1$ de Trizol, e as suspensões agitadas em Vortex e incubadas por 5 min a $25^{\circ} \mathrm{C}$.

Após o tratamento com Trizol, foram adicionados $107 \mu \mathrm{l}$ de clorofórmio (Synth, São Paulo, Brasil), e a suspensão agitada manualmente por 15 seg. e o lisado incubado novamente por mais $15 \mathrm{~min}$ a $25^{\circ} \mathrm{C}$, seguindo-se centrifugação a $12.000 \mathrm{xg} / 15 \mathrm{~min} / 4^{\circ} \mathrm{C}$. O RNA na fase aquosa foi transferido para um novo tubo estéril, e precipitado pela adição de $270 \mu \mathrm{l}$ de álcool isopropílico (Merck, Darmstadt, Alemanha), seguindo-se incubação por $10 \mathrm{~min} / 30{ }^{\circ} \mathrm{C}$ e centrifugação a $12.000 \mathrm{xg} / 10 \mathrm{~min} / 4^{\circ} \mathrm{C}$. O sobrenadante foi descartado e o RNA foi lavado com $600 \mu \mathrm{l}$ de etanol 75\% (Synth, São Paulo, Brasil) e centrifugado 7500xg / $5 \mathrm{~min} / 4{ }^{\circ} \mathrm{C}$. O sobrenadante foi novamente desprezado e o RNA ressuspenso em $50 \mu \mathrm{l}$ de água livre de RNAse (Qiagen Inc., Valencia, CA, EUA). Para remover os traços do DNA contaminante, as amostras foram tratadas com $2 \mu \mathrm{l}$ de DNAse I (Invitrogen) e incubadas a $25{ }^{\circ} \mathrm{C}$ por $10 \mathrm{~min}$. A quantificação do RNA foi realizada em espectrofotômetro NanoDrop ND-1000 (NanoDrop Technologies, Wilmington, DE, EUA).

\subsubsection{RT-PCR}

Para a síntese de c-DNA foi utilizada reação contendo $1 \mu \mathrm{l}$ do RNA total (obtido como descrito no item 3.5.1), $1 \mu \mathrm{l}$ de hexâmeros randômicos (50ng/ $\mu \mathrm{l}), 1 \mu \mathrm{l}$ de dNTP (10mM) e $7 \mu 1$ de $\mathrm{H} 2 \mathrm{O}$ livre de Rnase, num total de reação de $10 \mu 1$. A mistura de reação foi incubada a $65^{\circ} \mathrm{C}$ por 5 min e posteriormente resfriada em gelo por $1 \mathrm{~min}$. Em seguida, foram adicionados à mistura $2 \mu 1$ de 10X RT buffer, $4 \mu 1$ de $\mathrm{MgCl}_{2}(25 \mathrm{nM}), 2 \mu 1$ de DTT (0,1M), $1 \mu 1$ de RNase OUT (40U/ $\mu \mathrm{l})$ e $1 \mu \mathrm{l}$ de Super Script III RT (200U/ $\mu$ l), utilizando-se o kit Platinum quantitative RTPCR Thermoscript one-step system (Gibco, Grand Island, NY, EUA) de acordo com as instruções do fabricante. As reações de transcriptase reversa foram incubadas por $10 \mathrm{~min}$ a $25^{\circ} \mathrm{C}$, $50 \mathrm{~min}$ a $50{ }^{\circ} \mathrm{C}$ e $5 \mathrm{~min}$ a $85^{\circ} \mathrm{C}$. Posteriormente, as msituras foram centrifugadas e adicionadas de $1 \mu \mathrm{l}$ de RNase $\mathrm{H}$, seguindo-se nova incubação a $37{ }^{\circ} \mathrm{C}$ por 20 min. Foram utilizados 2 controles: a) sem adição de RNA; b) com adição de RNA e sem adição de Super Script III RT. O c-DNA foi estocado a $-20^{\circ} \mathrm{C}$ até o momento do uso. 


\subsubsection{PCR quantitativo}

A transcrição relativa dos genes $l t x$, flp, aae, apaH, omp29, omp100 (apiA), cdtB, vppA, vapA, orf 859, emaA, cagE, pgA foi analisada utilizando-se os iniciadores descritos na Tabela 2, sintetizados por Invitrogen. Foi determinada a transcrição relativa dos genes em relação à gapdh (gliceraldeido 3-fosfato desidrogenase) (RICHARDSON et al., 2005) em A. actinomycetemcomitans. Os iniciadores para amplificação dos genes flp, omp29, cdtB por PCR em tempo real foram desenhados utilizando o programa do site www.genscript.com/sslbin/app/primer. O programa DNAstar foi usado para desenhar os iniciadores que amplificam as regiões ltx, emaA, cagE e pga.

Após a síntese de cDNA, conforme descrito no item 3.5.2 foi realizada a reação de PCR quantitativo em que foram adicionados: $10 \mu \mathrm{l}$ de SYBR Green (Biotools, Madrid, Espanha), 0,16 $\mu 1$ de cada par de iniciadores (200nM) (Tabela 2), 100ng de c-DNA molde e água estéril para completar o volume total de $20 \mu \mathrm{l} /$ reação. A concentração de Cloreto de Magnésio $\left(\mathrm{MgCl}_{2}\right)$ adicionada à reação de PCR em tempo real foi padronizada para cada par de iniciadores, conforme descrito na Tabela 3. A reação de amplificação compreendeu 48 ciclos de $95{ }^{\circ} \mathrm{C}$ por 10 seg. e $50^{\circ} \mathrm{C}$ por $1 \mathrm{~min}$. (CAO et al., 2004) utilizando-se termociclador iQ 5 Bio-Rad (Bio Rad, Hercules, CA, EUA). Após a reação foi realizada a curva de melting para determinar a especificidade dos amplicons, sendo usados 100 ciclos de 10 seg., com aumento de temperatura de $0,4{ }^{\circ} \mathrm{C} /$ ciclo de $55^{\circ} \mathrm{C}$ a $95^{\circ} \mathrm{C}$ (RICHARDSON et al., 2005).

A análise da expressão gênica bacteriana foi realizada utilizando o software Rest 2005 (PFAFFL; HORGAN; DEMPFLE, 2002) a partir do estabelecimento do ciclo limiar (Threshold Cycle - $\mathrm{C}_{\mathrm{T}}$ ), obtidos do software iQ5 Optical System (Bio-Rad).

A transcrição relativa de cada um dos genes foi normalizada em relação aos níveis de transcritos observados para gapdH. Após o cálculo dos níveis médios, desvio e erro padrão da transcrição relativa de cada um dos genes em cada uma das quatro condições testadas (controle e adesão em 2 horas; controle e adesão em 24 horas), foram comparados os níveis de transcrição relativa de cada um dos genes entre as amostras em cada uma das condições pelo teste de Anova e pós-teste de Tukey. Também foram comparados os níveis de transcrição de cada um dos genes nas amostras após a adesão às células epiteliais e seus respectivos controles utilizando a mesma 
análise estatísitica (Anova e pós-teste de Tukey). Foram consideradas diferenças significantes quando $\mathrm{p}<0,05$. 
Tabela 2- Seqüência dos iniciadores utilizados em reações de PCR em tempo real para análise da expressão gênica de A. Actinomycetemcomitans.

\begin{tabular}{|c|c|c|c|}
\hline Gene & Seqüência Nucleotídica & $\begin{array}{l}\text { Produto } \\
(\text { pb })\end{array}$ & Referência \\
\hline $\begin{array}{l}\text { ORF1383 } \\
\text { (A.a.gapdh) }\end{array}$ & $\begin{array}{l}\text { 5' CCCAAAACATCATCCCATCTTC 3' } \\
\text { 5' GGAACACGGAACGCCATAC 3' }\end{array}$ & $60 \mathrm{pb}$ & Richardson et al. (2005) \\
\hline ltx & $\begin{array}{l}\text { 5' TTGTCGCAAGTGCCATAGTTATCCAC 3' } \\
5 \text {, TAGCCCCATGGCAACGGTAGAA 3' }\end{array}$ & $193 \mathrm{pb}$ & Este estudo \\
\hline$f l p$ & $\begin{array}{l}5^{\prime} \text { TCAAAGCAATCGAAGCAATC 3' } \\
5^{\prime} \text { GCAATAGCGATCAAACCGTA 3' }\end{array}$ & $82 \mathrm{pb}$ & Este estudo \\
\hline aae & $\begin{array}{l}\text { 5' GGTTTTAGGCGGCACATTTA 3' } \\
\text { 5' TGCTTGACCAACCATAACCA 3' }\end{array}$ & $152 \mathrm{pb}$ & Este estudo \\
\hline apaH & $\begin{array}{l}\text { 5' CACCTTGGTTTGCCTTGGATA 3' } \\
\text { 5' TGTCTTCCCAACGTAGCATG 3' }\end{array}$ & $159 \mathrm{pb}$ & $\begin{array}{l}\text { P.Longo (Processo } \\
\text { FAPESP 03/01192-9) } \\
\text { Saarela et al. (1999) }\end{array}$ \\
\hline отр29 & $\begin{array}{l}5, \text { TCTCAACAAGCCATCTCTGC 3, } \\
5, \text { CGACCTTTAACTACGTCGCA } 3 \text {, }\end{array}$ & $80 \mathrm{pb}$ & Este estudo \\
\hline omp100 & $\begin{array}{l}\text { 5' ATCTTCAAGCCAAAACATC 3' } \\
\text { 5' AAGGCTGCCGACATTAT 3' }\end{array}$ & $169 \mathrm{pb}$ & Yue et al. (2007) \\
\hline$c d t B$ & $\begin{array}{l}\text { 5' CAACAACACAATTCCAACCC 3' } \\
\text { 5' GGCGATACCTGTCCATTCTT 3' }\end{array}$ & $94 \mathrm{pb}$ & Este estudo \\
\hline vapA & $\begin{array}{l}\text { 5' CGAAATTATGGCTGGGTATGC 3', } \\
\text { 5' AATGGTTGGATGTTGAATACGG 3' }\end{array}$ & $60 \mathrm{pb}$ & Cao et al. (2004) \\
\hline orf 859 & $\begin{array}{l}\text { 5' CAATCTCACCCAAGCCCTAC 3', } \\
\text { 5' GCGGCGGAAATATAGAAACTG 3' }\end{array}$ & $83 \mathrm{pb}$ & Cao et al. (2004) \\
\hline vppA & $\begin{array}{l}\text { 5' GGTTACCGGTGGAGTTCG 3', } \\
\text { 5' CGGGTCGTAATCGTTTGA 3', }\end{array}$ & $190 \mathrm{pb}$ & $\begin{array}{l}\text { Mayer MP. (Processo } \\
\text { FAPESP 98/15596-4) }\end{array}$ \\
\hline $\operatorname{cag} E$ & $\begin{array}{l}5, \text { TGGATTGGGACAAGTGAACA } 3, \\
5 \text {, TACAAAGCCATAAGAGAAAT } 3\end{array}$ & $190 \mathrm{pb}$ & Este estudo \\
\hline emaA & $\begin{array}{l}\text { 5' CTGCAGCAACCGGGGATTAT 3' } \\
\text { 5' AATGGATTGGTTGCCTTTAG 3' }\end{array}$ & $110 \mathrm{pb}$ & Este estudo \\
\hline$p g A$ & $\begin{array}{l}\text { 5' GACGGTGATGCGGTATTGG 3', } \\
\text { 5' GACCGATGATGGAGCTGAA 3' }\end{array}$ & $160 \mathrm{pb}$ & $\begin{array}{l}\text { Kaplan et al. (2004) } \\
\text { P. Longo (Processo } \\
\text { FAPESP 03/01192-9) }\end{array}$ \\
\hline
\end{tabular}


Tabela 3- Concentração de Cloreto de Magnésio $\left(\mathrm{MgCl}_{2}\right)$ utilizada nas reações de PCR em tempo real para cada par de iniciador.

\begin{tabular}{|c|c|c|}
\hline Par de iniciador & $\begin{array}{l}\text { Concentração de Cloreto de } \\
\text { Magnésio }\left(\mathrm{MgCl}_{2}\right) \text { em } \mathrm{mM}\end{array}$ & Eficiência da reação \\
\hline $\begin{array}{l}\text { ORF1383 } \\
(\text { A.a.gapdh) }\end{array}$ & $3,0 \mathrm{mM}$ & $85 \%$ \\
\hline ltx & $3,0 \mathrm{mM}$ & $104,6 \%$ \\
\hline$f l p$ & $4,5 \mathrm{mM}$ & $95,2 \%$ \\
\hline aae & $3,0 \mathrm{mM}$ & $109,8 \%$ \\
\hline$a p a \mathrm{H}$ & $4,5 \mathrm{mM}$ & $88,4 \%$ \\
\hline omp29 & 7,5 mM & $81,3 \%$ \\
\hline omp100 & 4,5 mM & $127,0 \%$ \\
\hline$c d t B$ & $3,0 \mathrm{mM}$ & $92,9 \%$ \\
\hline vapA & $4,5 \mathrm{mM}$ & $99,6 \%$ \\
\hline orf 859 & $3,0 \mathrm{mM}$ & $88,5 \%$ \\
\hline$v p p A$ & $3,0 \mathrm{mM}$ & $97,4 \%$ \\
\hline $\operatorname{cag} E$ & $4,5 \mathrm{mM}$ & $92,8 \%$ \\
\hline emaA & $3,0 \mathrm{mM}$ & $97,5 \%$ \\
\hline$p g A$ & $3,0 \mathrm{mM}$ & $92,9 \%$ \\
\hline
\end{tabular}




\subsubsection{Curva padrão}

Para a obtenção da curva padrão nas reações de PCR quantitativo para cada par de iniciador, foram utilizadas diluições seriadas decimais de cada um dos amplicons purificados. As reações de amplificação foram realizadas utilizando $1 \mu 1$ de DNA molde da amostra SUNY 465, 1,5U de Taq DNA polimerase (Invitrogen), 0,2 $\mathrm{mM}$ de dNTP (Invitrogen), $2 \mathrm{mM}$ de $\mathrm{MgCl}_{2}, 2,5$ $\mu 1$ de tampão (10X PCR buffer), 0,5 $\mu 1$ de cada iniciador (25pM), descritos na Tabela 2, em total de $25 \mu 1$ de reação. Os produtos das amplificações de PCR e o marcador de peso molecular de 100 bp (Fermentas Inc., Glen Burnie, MD, EUA) foram submetidos a eletroforese em gel de agarose a 0,7\% em tampão TAE, corados com brometo de etídio e fotografados.

Em seguida, os amplicons foram excisados do gel e purificados com auxílio do Kit GFX (Amershan Biosciences, Buckinghamshire, Inglaterra) seguindo as instruções do fabricante. Os amplicons purificados foram quantificados por leitura da absorbância em espectrofotômetro NanoDrop ND-1000 (NanoDrop Technologies, Wilmington, DE, EUA). A seguir, alíquotas de diluições em série, contendo $0,1 \mathrm{ng} ; 0,01 \mathrm{ng} ; 0,001 \mathrm{ng}$ e $0,0001 \mathrm{ng}$ de cada produto foram empregadas nas reações de PCR em tempo real, para obtenção da curva padrão.

\subsection{Análise da transcrição gênica de célula epitelial OBA-9 após interação com $A$. actinomycetemcomitans}

Esta etapa foi realizada no laboratório de Microbiologia, School of Dental Medicine, University of Louisville, Louisville, KY, EUA, sob a orientação do Prof. Dr. Donald Demuth, em bolsa de doutorado sanduíche. Foram realizados estudos prévios com a amostra de Aggregatibacter actinomycetemcomitans JP2, quanto à capacidade de adesão e invasão em diferentes intervalos de tempo: 2, 12 e 24 horas de infecção em células de linhagem epitelial gengival OBA-9. A análise de transcrição gênica foi realizada em células OBA-9 em co-cultura por 24 horas com a amostra JP2, visto que esta cepa caracteriza o clone JP2 associado à maior virulência (HAUBEK et al., 2007). 


\subsubsection{Condições de cultura bacteriana}

Alíquota do estoque congelado mantidas em glicerol $20 \%$, a $-80{ }^{\circ} \mathrm{C}$ da amostra de Aggregatibacter actinomycetemcomitans JP2 foi cultivada na superfície de Ágar Infuso Cerebro e Coração (BHI) (Difco, Sparks, MD, EUA) suplementado com $40 \mu \mathrm{g} / \mathrm{ml}$ de bicarbonato de sódio e e incubada em estufa com atmosfera de $10 \%$ de $\mathrm{CO}_{2}\left(\right.$ Shel Lab) por 24 horas a $37{ }^{\circ} \mathrm{C}$. As colônias foram raspadas com alça Drigalski estéril, inoculadas em $8 \mathrm{ml}$ de caldo BHI suplementado com $40 \mu \mathrm{g} / \mathrm{ml}$ de bicarbonato de sódio e a cultura incubada durante 8 horas em estufa com atmosfera de $10 \%$ de $\mathrm{CO}_{2}$. Após este intervalo de tempo, a concentração da suspensão bacteriana foi ajustada à DO $495 \mathrm{~nm}$ 1,0 por mensuração em espectrofotômetro, seguindo-se diluição 1:40 em caldo BHI e incubação por 7 horas, até que a cultura tenha alcançado o meio da fase exponencial.

\subsubsection{Adesão de Aggregatibacter actinomycetemcomitans à célula epitelial em diferentes intervalos de tempo}

As suspensões bacterianas em meio de fase exponencial foram ajustadas a $\mathrm{DO}_{495}=0,2 \mathrm{e}$ alíquotas de $100 \mu 1$, correspondendo a $3 \times 10^{7} \mathrm{UFC} / \mathrm{ml}$ foram centrifugadas a $5.200 \mathrm{xg}$ durante 1 min a $4{ }^{\circ} \mathrm{C}$. O sobrenadante foi desprezado e o precipitado ressuspenso em $50 \mu \mathrm{ml}$ de PBS (0,1M; pH 7,4), seguindo-se agitação em Vortex por 30 seg. A suspensão foi inoculada em 950 $\mu 1$ de meio queratinócito livre de soro - KSFM (Invitrogen, Carlsbad, CA) /sem antibiótico, adicionada à monocamada de células epiteliais OBA-9 em poços de placas de 24 poços $\left(3 \times 10^{5}\right.$ células/poço), obtidas como descrito no item 3.3 a uma MOI de 1:100.

As placas contendo células OBA-9 e suspensões bacterianas foram submetidas à centrifugação de $593 x$ g por 10 minutos à $20^{\circ} \mathrm{C}$ e incubadas por períodos de 2 , 12 e 24 horas em estufa a $37^{\circ} \mathrm{C}$. Em seguida, os poços foram lavados três vezes com PBS para remoção das células não aderidas.

Para a estimativa do número de células bacterianas aderidas, as células epiteliais foram tripsinizadas adicionando-se $1 \mathrm{ml}$ de tripsina, seguido-se incubação por 4 min. em estufa de $5 \%$ de $\mathrm{CO}_{2}$. Alíquotas de $100 \mu 1$ de diluições seriadas da suspensão de células foram inoculadas em 
triplicata na superfície de Ágar BHI e as placas incubadas por 72 horas em estufa com atmosfera de $10 \%$ de $\mathrm{CO}_{2}$ a $37^{\circ} \mathrm{C}$, para posterior contagem de viáveis (UFC) e cálculo do número de bactérias aderidas às células epiteliais/ poço.

\subsubsection{Invasão de Aggregatibacter actinomycetemcomitans à célula epitelial em diferentes intervalos de tempo}

A capacidade invasiva da cepa JP2 foi deteminada nos intervalos de 2, 12 e 24 horas de infecção. As suspensões bacterianas preparadas conforme descrito no item 3.6.2, foram incubadas nos mesmo intervalos de tempo analisadas para adesão.

As placas contendo células OBA-9 e suspensões bacterianas foram submetidas à centrifugação de $593 x$ g por 10 minutos a $20^{\circ} \mathrm{C}$ e incubadas por períodos de 2 , 12 e 24 horas em estufa a $37^{\circ} \mathrm{C}$. Após o periodo de infecção, os poços foram lavados três vezes com PBS para remoção das células não aderidas, e então as células foram tratadas durante 1 hora com solução antibiótica contendo $100 \mu \mathrm{g} / \mathrm{ml}$ de gentamicina (Sigma Chemical Co, St Louis, MO, EUA) em meio KSFM para eliminar as bacterias extracelulares. Em seguida, foram realizadas lavagens

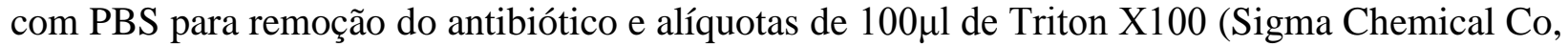
St Louis, MO, EUA) a 0,5\% foram adicionados aos poços, para promover a lise celular e liberação das bacterias internalizadas. Após a lise, o detergente foi diluído com PBS. Alíquotas de $100 \mu \mathrm{l}$ de diluições das suspensões foram inoculadas em triplicata na superfície de ágar BHI e as placas incubadas durante 72 horas em estufa com atmosfera de $10 \%$ de $\mathrm{CO}_{2}$ a $37{ }^{\circ} \mathrm{C}$, para posterior contagem de viáveis (UFC), e cálculo do número de bactérias internalizadas nas células epiteliais/poço.

\subsubsection{Análise da transcrição gênica da célula epitelial OBA-9 após 24 horas de infecção com JP2}

A análise da transcrição gênica foi realizada com a amostra JP2, sendo esta, aderente e invasiva em diferentes intervalos de tempo testados. A análise foi realizada após 24 horas de infecção a uma MOI de 1:100. Este período foi escolhido pois estudos anteriores (MILWARD et 
al., 2007) mostraram ser este tempo mais representativo da resposta celular frente ao estímulo bacteriano. A extração de RNA foi obtida adicionando-se $100 \mu$ l de Trizol (Invitrogen) em cada um dos 4 poços utilizados para cada amostra e 4 poços para o controle sem a presença da bactéria. As suspensões celulares foram homogeneizadas e transferidas para um tubo de centrífuga estéril, agitadas em Vortex e incubadas por 5 min a $25^{\circ} \mathrm{C}$ para permitir a completa dissociação do complexo nucleoproteico. Em seguida, foi adicionado $107 \mu$ de clorofórmio (Merck, Darmstadt, Alemanha), agitado vigorosamente com a mão por 15 seg. e o lisado incubado novamente por mais $15 \mathrm{~min}$ a $25^{\circ} \mathrm{C}$, seguindo-se de centrifugação a $12.000 \times \mathrm{xg} / 15 \mathrm{~min} /$ $4{ }^{\circ} \mathrm{C}$. O RNA na fase aquosa foi transferido cuidadosamente para um novo tubo estéril, e precipitado pela adição de $214 \mu \mathrm{l}$ de álcool isopropílico (Merck). Após incubação por $10 \mathrm{~min} / 30$ ${ }^{\circ} \mathrm{C}$ e centrifugação a $12.000 \mathrm{xg} / 10 \mathrm{~min} / 4^{\circ} \mathrm{C}$. O sobrenadante foi descartado e o RNA contido no precipitado foi lavado com $426 \mu \mathrm{l}$ de etanol 75\% (Merck) e centrifugado $7500 \mathrm{xg} / 5 \mathrm{~min} / 4^{\circ} \mathrm{C}$. O sobrenadante foi novamente desprezado e o RNA ressuspenso em $25 \mu$ de água livre de RNAse (Qiagen Inc., Valencia, CA, EUA). A quantificação do RNA foi realizada em Espectrofotômetro (Nanodrop).

Após a obtenção do RNA, foi utilizado o kit RT ${ }^{2}$ Profiler PCR Array Human Signal Transduction PathwayFinder (PAHS-014A) (SABiosciences Corporation, MD, USA), para análise da transcrição de genes da célula epitelial relacionados à transdução de sinais. Este kit contém um arranjo (array) de 84 pares de iniciadores que amplificam regiões relacionadas às diferentes vias sinalização da transdução de sinais, incluindo 5 controles internos: beta-2microglobulina (B2M), hipoxantina fosforibosiltransferase-1 (HPRT1), proteina ribossomal L13A (RPL13A), gliceraldeído-3-fosfato desidrogenase (GAPDH) e beta-actina (ACTB). Além disso, incluem controles quanto à contaminação por DNA, sendo um para detecção de contaminação de DNA genômico humano, triplicata de controles da transcrição reversa e triplicata de controles positivos de PCR, totalizando um arranjo de 96 pares de iniciadores (Anexo A). $1 \mu \mathrm{g}$ de RNA, obtido das células OBA-9 infectadas e não infectadas foi tratado com DNAse e a sintese de c-DNA foi realizada empregando-se o kit RT First Strand kit (C-03). A reação de PCR quantitativo foi realizada utilizando-se o Super Array RT qPCR Master Mix. A reação consistiu em: $1.275 \mu \mathrm{l}$ de Super Array Master Mix contendo SYBR Green, $102 \mu 1$ de cDNA e $1.173 \mu \mathrm{l}$ de água livre de RNAse. Em seguida, alíquotas de $25 \mu \mathrm{l}$ da mistura foram adicionadas a cada poço contendo os iniciadores para cada gene analisado. 
O ciclo de amplificação em termociclador (Applied Biosystems 7500) compreendeu 1 ciclo de $95^{\circ} \mathrm{C}$ por 10 min., seguidos de 40 ciclos de $95^{\circ} \mathrm{C}$ por 15 seg. e $60{ }^{\circ} \mathrm{C}$ por 1 min. Após a reação, os dados de ciclo limiar $(\mathrm{Ct})$ obtidos foram analisados utilizando-se o programa no site www.superarray.com/pcr/arrayanalysis.php (SABIOSCIENCES CORPORATION, [2008])

\subsection{Ensaio imunoenzimático (ELISA) para detecção de GM-CSF/CSF2, TNF- $\alpha$ e ICAM-1}

\subsubsection{Análise no sobrenadante de culturas de células in vitro}

Foram analisados os níveis de cada um dos mediadores inflamatórios (GM-CSF/CSF2, TNF- $\alpha$ e ICAM-1) no sobrenadante das culturas celulas OBA-9 após os ensaios de interação com a amostra JP2 por 24 horas, conforme ensaio descrito no item 3.6.4. Todos os ensaios foram realizados em triplicata. Foi utilizado como controle, o sobrenadante da cultura de células epiteliais sem adição da bactéria, submetidas às mesmas condições.

\subsubsection{Análise em amostras de tecido gengival}

Amostras de tecido gengival obtidas de pacientes com diferentes condições periodontais (saúde, periodontite agressiva e crônica) foram utilizadas para determinação da concentração de CSF2/GM-CSF, TNF- $\alpha$ e ICAM -1. As amostras de tecido gengival foram cedidas pelo Prof. Dr. Marcelo de Faveri da Universidade de Guarulhos, obtidas em estudo aprovado pelo Comitê de Ética em Pesquisa em seres humanos daquela instituição (PARECER nº 190/2009, aprovado em 01.09.2009), seguida da aprovação do do CEP do Instituto de Ciências Biomédicas da Universidade de São Paulo.

\subsubsection{Obtenção das amostras de tecido gengival}

Foram analisadas amostras de tecido gengival de indivíduos sem perda de inserção clínica e saudáveis (periodonto saudável) $(n=12)$, periodontite agressiva $(n=10)$ e periodontite crônica $(n=11)$. De cada indivíduo foi coletada uma amostra de tecido gengival obtida durante 
cirurgia visando o tratamento periodontal dos pacientes com periodontite, e obtida de sítio requerendo cirugia para aumento de coroa clínica dos pacientes sem perda de inserção. Os critérios de inclusão e exclusão estão descritos a seguir:

- Critérios de inclusão dos pacientes:

a) Periodontite Agressiva:

$-\leq 35$ anos de idade;

- mínimo de 6 dentes, entre incisivos permanentes e/ou primeiros molares, cada sítio apresentando profundidade de sondagem e nível de inserção clínica $\geq 5 \mathrm{~mm}$ (forma localizada);

- mínimo de 6 dentes, além dos incisivos e primeiros molares com profundidade de sondagem e nível de inserção clínica $\geq 5 \mathrm{~mm}$ (forma generalizada)

- agregação familiar (apresentar ao menos um outro membro da família com história de periodontite).

b) Periodontite Crônica

- >35 anos de idade

- mínimo de seis dentes apresentando profundidade de sondagem e nível de inserção clínica $\geq 5 \mathrm{~mm}$ em cada sítio;

- apresentar profundidade de sondagem e nível de inserção clínica $\geq 4 \mathrm{~mm}$ em pelo menos $30 \%$ dos sítios e sangramento à sondagem;

c) Saudável:

- > 25 anos de idade;

- não apresentar sítios com nível de inserção clínica > $3 \mathrm{~mm} \mathrm{e}<20 \%$ dos sítios apresentando sangramento gengival e/ou sangramento à sondagem.

- Critério de exclusão dos pacientes:

- gestantes, mães lactentes, fumantes, terapia periodontal prévia, condição sistêmica que comprometa a progressão da doença periodontal (ex.: diabetes, complicações imunológicas), administração de medicação anti-inflamatória, necessidade de 
cobertura antibiótica para tratamento dental e histórico de terapia antibiótica nos últimos 6 meses.

\subsubsection{Processamento das amostras de tecido gengival}

$10 \mathrm{mg}$ de tecido gengival foram adicionados a $500 \mu \mathrm{l}$ de tampão de lise (PBS (1X) / 0,05\% Tween20/1mM de Inibidor de Protease - Sigma) e homogeneizados. Após centrifugação a $500 \mathrm{~g} / 10 \mathrm{~min}$, o sobrenadante coletado foi estocado em freezer $-80{ }^{\circ} \mathrm{C}$ até o momento do uso.

\subsubsection{ELISA}

Foram utilizados kits de detecção de citocinas humanas GM-CSF/CSF2 (Peprotech Inc., Rocky Hill, NJ, USA), TNF- $\alpha$ (Peprotech Inc., Rocky Hill, NJ, USA) e ICAM-1 (R\&D Systems, Minneapolis, MN, USA) seguindo as instruções do fabricante, tanto para células epiteliais como para as amostras de tecido gengival.

Placas de 96 poços (Corning-Costar, Lowell, MA, EUA) foram recobertas com $100 \mu 1 /$ poço do anticorpo de captura nas concentrações de $2 \mu \mathrm{g} / \mathrm{ml}$ (GM-CSF), $1 \mu \mathrm{g} / \mathrm{ml}$ (TNF- $\alpha$ ) e $4 \mu \mathrm{g} / \mathrm{ml}$ ICAM-1 e incubadas por 12-16 horas à temperatura ambiente. Após 4 lavagens com tampão $(0,05 \%$ Tween-20 em PBS(1X)), os poços foram preenchidos com solução bloqueadora (1\% albumina sérica bovina - BSA em PBS(1X)), e incubados por 1 hora. Após as lavagens com solução de PBSTween 20, foram adicionadas as amostras (itens 3.7.1 e 3.7.2) e incubadas por 2 horas. Após as lavagens, os anticorpos de detecção foram adicionados [0,25 $\mu \mathrm{g} / \mathrm{ml}$ (GM-CSF), 0,5 $\mu \mathrm{g} / \mathrm{ml}$ (TNF- $\alpha$ ), $0,1 \mu \mathrm{g} / \mathrm{ml}$ (ICAM)] e incubados por 2 horas. As avidinas (diluições 1:2000 para GM-CSF e TNF) e streptavidina (1:200 para ICAM-1) foram adicionadas e incubadas por 20 minutos. A reação foi revelada pela adição do substrato OPD (o-fenilenediamine, Sigma-Aldrich) em tampão citratofosfato $0,05 \mathrm{M}, \mathrm{pH}$ 5,0 e incubação por 10 minutos. A leitura foi realizada em comprimento de onda de $450 \mathrm{~nm}$ e correção a $550 \mathrm{~nm}$ em leitor de ELISA (Modelo 680, BioRad). 


\section{RESULTADOS}

\subsection{Adesão de Aggregatibacter actinomycetemcomitans às células epiteliais}

A eficiência da adesão às células OBA-09 após 2 horas de infecção de cada uma das amostras de A. actinomycetemcomitans testadas em uma multiplicadade de infecção (MOI) de 1:3.000 foi de (média \pm desvio padrão): $1,2 \% \pm 0.62$ para SUNY465; $0,41 \% \pm 0,014$ para a cepa JP2 e 0,31\% $\pm 0,14$ para a cepa ATCC 29523. Por outro lado, quando foi utilizada a MOI de 1:100, a eficiência de adesão da amostra JP2 foi de 6,43\% $\pm 2,04$ e de invasão $0,0007 \% \pm$ 0,000006. No presente estudo a menor concentração de bactérias (MOI 1:100) foi utilizada para análise da expressão gênica da célula epitelial após infecção por A. actinomycetemcomitans enquanto a MOI 1:3.000 foi empregada para a análise da expressão gênica bacteriana. A utilização de maior quantidade de bactérias no último ensaio foi devida à necessidade de material suficiente para a extração de RNA bacteriano, de acordo com estudo anterior (RICHARDSON et al., 2005). A porcentagem de adesão pode ser influenciada pela concentração bacteriana utilizada, em que altas concentrações bacterianas provocam saturação dos sítios de ligação (MINTZ et al., 1994). Isso refletiu em diferentes resultados eficiência de adesão para a amostra JP2, onde a maior eficiência de adesão foi obtida com multiplicidade de infecção de 1:100.

\subsection{Análise da expressão gênica de Aggregatibacter actinomycetemcomitans após a adesão a célula epitelial gengival OBA-9 e no controle sem a presença da célula epitelial.}

Após a padronização das reações e estabelecida a eficiência de cada uma das reações, com diferentes concentrações de Cloreto de Magnésio, foi analisado o perfil de transcrição das cepas ATCC29523, SUNY 465 e JP2, após a adesão com célula epitelial (MOI 1:3000) e controle. Os dados de transcrição relativa de cada um dos genes foram analisados em relação a transcrição do gene orf1383 ou gapdh (codificando a enzima gliceraldeído 3-fosfato desidrogenase) (RICHARDSON et al., 2005) em A. actinomycetemcomitans. Em estudo piloto, os valores de todos os genes foram normalizados com o controle interno $16 \operatorname{SrRNA}$, porém, a maioria dos genes analisados não foi transcrita a níveis detectáveis (dados não apresentados), 
visto que este gene é altamente expresso, apresentando 6 cópias no genoma de HK1651 (RICHARDSON et al., 2005). Assim os dados apresentados referem-se à transcrição de gapdh (orf 1383).

Os níveis de transcrição relativa de cada um dos genes estudados nas quatro condições estão apresentados nas tabelas 4 a 7: controle em 2 horas (tabela 4), adesão em 2 horas (tabela 5), controle em 24 horas (tabela 6), adesão em 24 horas (tabela 7). A determinação de diferenças nos níveis de transcrição entre as as diferentes amostras, em cada uma das condições, foi realizada empregando-se ANOVA com dois fatores, seguida por comparações múltiplas pelo método de Tukey e as diferenças consideradas significantes quando $\mathrm{p}<0,05$.

Para possiblitar melhor visualização e permitir comparações não somente entre as amostras, mas também na mesma amostra em cada uma das condições testadas, os dados de transcrição relativa estão também apresentados nas Figuras 3 a 15.

Os dados de transcrição relativa de genes de A. actinomycetemcomitans, revelaram variabilidade na expressão gênica bacteriana com diferenças estatisticamente significantes entre as amostras ATCC29523, SUNY 465 e JP2 quando submetidas às mesmas condições ambientais. O intervalo de infecção também foi determinante para a transcrição de alguns genes.

O gene $f l p$ (que codifica a adesina fimbrial) foi pouco transcrito no controle e após $2 \mathrm{~h}$ de infecção por todas as amostras, como esperado, visto que as culturas apresentavam fenótipo liso. No entanto, a expressão de $f l p$ foi regulada positivamente após adesão em 24 horas principalmente na amostra ATCC29523 e em menor grau na amostra JP2, mas não para a SUNY 465, como demonstrado nas Figuras 3A e B.

A transcrição dos genes aae e omp100 foi regulada positivamente após $2 \mathrm{~h}$ de interação com células epiteliais na amostra ATCC 29523 (Figuras 4A e 6A). Além disso, em ATCC29523, os genes aae, apaH e omp100, que codificam adesinas relacionadas com a interação com células epitelias, foram regulados positivamente após $24 \mathrm{~h}$ de interação com células (Figuras 4B, 5B e 6B), sendo os níveis de transcrição de aae e apaH nesta amostra foi bem maior que nas demais. 
Tabela 4- Valores médios e desvio padrão de dois ensaios independentes realizados em triplicata dos níveis de transcrição de cada um dos genes normalizados em relação à transcrição de gapdH das três amostras de A. actinomycetemcomitans na condição controle sem célula epitelial após 2 hs de incubação (Média \pm Desvio padrão). Teste Anova-Tukey. AS (ausência de diferença estatisticamente significante entre amostras).

\begin{tabular}{|c|c|c|c|c|}
\hline \multirow[b]{2}{*}{ Gene } & \multicolumn{3}{|c|}{ Amostra } & \multirow[b]{2}{*}{$\begin{array}{c}\text { Diferença significante } \\
\mathbf{p}<\mathbf{0 , 0 5}\end{array}$} \\
\hline & $\begin{array}{c}\operatorname{ATCC} 29523 \\
\text { (a) }\end{array}$ & $\begin{array}{l}\text { SUNY } 465 \\
\text { (b) }\end{array}$ & $\begin{array}{c}\text { JP2 } \\
\text { (c) }\end{array}$ & \\
\hline$f l p$ & $0,27 \pm 0,02$ & $0,16 \pm 0,01$ & $0,25 \pm 0,045$ & $\begin{array}{l}a \neq b \\
b \neq c\end{array}$ \\
\hline aae & $0,001 \pm 0,00$ & $0,39 \pm 0,03$ & $1,048 \pm 0,52$ & $\mathrm{a} \neq \mathrm{b} \neq \mathrm{c}$ \\
\hline apaH & $0,16 \pm 0,03$ & $0,42 \pm 0,09$ & $2,22 \pm 0,67$ & $\begin{array}{l}\mathrm{a} \neq \mathrm{c} \\
\mathrm{b} \neq \mathrm{c}\end{array}$ \\
\hline omp100 & $0,001 \pm 0,0$ & $0,005 \pm 0,004$ & $0,07 \pm 0,04$ & AS \\
\hline$e m a A$ & $0,00 \pm 0,00$ & $0,052 \pm 0,01$ & $0,27 \pm 0,00$ & $\mathrm{a} \neq \mathrm{b} \neq \mathrm{c}$ \\
\hline ltx & $0,00 \pm 0,00$ & $2,80 \pm 0,72$ & $9,43 \pm 2,39$ & $a \neq b \neq c$ \\
\hline$c d t B$ & $0,34 \pm 0,04$ & $2,81 \pm 0,83$ & $9,95 \pm 0,62$ & $a \neq b \neq c$ \\
\hline$v p p A$ & $0,005 \pm 0,00$ & $2,96 \pm 0,51$ & $9,41 \pm 1,68$ & $a \neq b \neq c$ \\
\hline orf859 & $0,00 \pm 0,00$ & $0,18 \pm 0,03$ & $0,11 \pm 0,00$ & $\mathrm{a} \neq \mathrm{b} \neq \mathrm{c}$ \\
\hline vapA & $0,01 \pm 0,003$ & $1,22 \pm 0,04$ & $4,54 \pm 0,19$ & $a \neq b \neq c$ \\
\hline $\operatorname{cag} E$ & $0,00 \pm 0,00$ & $0,00 \pm 0,00$ & $0,223 \pm 0,08$ & $\begin{array}{l}a \neq c \\
b \neq c\end{array}$ \\
\hline omp29 & $0,00 \pm 0,00$ & $0,20 \pm 0,012$ & $20,79 \pm 2,84$ & $\begin{array}{l}a \neq c \\
b \neq c\end{array}$ \\
\hline$p g A$ & $0,02 \pm 0,003$ & $0,30 \pm 0,10$ & $0,23 \pm 0,04$ & $\begin{array}{l}a \neq b \\
a \neq c\end{array}$ \\
\hline
\end{tabular}


Tabela 5- Valores médios e desvio padrão de dois ensaios independentes realizados em triplicata dos níveis de transcrição de cada um dos genes normalizados em relação à transcrição de gapdH das três amostras de A. actinomycetemcomitans após adesão em 2 hs de incubação (Média \pm Desvio padrão). Teste AnovaTukey. AS (ausência de diferença estatisticamente significante entre amostras).

\begin{tabular}{|c|c|c|c|c|}
\hline \multirow{2}{*}{ Gene } & \multicolumn{3}{|c|}{ Amostra } & \multirow[b]{2}{*}{$\begin{array}{c}\text { Diferença significante } \\
\mathbf{p}<\mathbf{0 , 0 5}\end{array}$} \\
\hline & $\begin{array}{c}\text { ATCC } 29523 \\
\text { (a) }\end{array}$ & $\begin{array}{l}\text { SUNY } 465 \\
\text { (b) }\end{array}$ & $\begin{array}{l}\mathbf{J P 2} \\
\text { (c) }\end{array}$ & \\
\hline$f l p$ & $0,30 \pm 0,07$ & $0,11 \pm 0,03$ & $0,36 \pm 0,25$ & $\begin{array}{l}a \neq b \\
b \neq c\end{array}$ \\
\hline aae & $0,43 \pm 0,03$ & $1,01 \pm 0,08$ & $0,54 \pm 0,28$ & AS \\
\hline apaH & $0,18 \pm 0,09$ & $0,00 \pm 0,0$ & $1,06 \pm 0,015$ & $\begin{array}{l}a \neq c \\
b \neq c\end{array}$ \\
\hline omp100 & $0,42 \pm 0,16$ & $0,50 \pm 0,29$ & $0,16 \pm 0,04$ & $\mathrm{~b} \neq \mathrm{c}$ \\
\hline$e m a A$ & $0,01 \pm 0,00$ & $0,019 \pm 0,003$ & $0,204 \pm 0,043$ & $\begin{array}{l}a \neq c \\
b \neq c\end{array}$ \\
\hline ltx & $0,36 \pm 0,08$ & $2,36 \pm 0,27$ & $10,76 \pm 4,72$ & $a \neq b \neq c$ \\
\hline$c d t B$ & $0,07 \pm 0,01$ & $0,89 \pm 0,69$ & $6,54 \pm 1,23$ & $\begin{array}{l}a \neq c \\
b \neq c\end{array}$ \\
\hline$v p p A$ & $0,54 \pm 0,21$ & $0,88 \pm 0,18$ & $5,64 \pm 0,65$ & $\begin{array}{l}a \neq c \\
b \neq c\end{array}$ \\
\hline orf859 & $0,00 \pm 0,00$ & $0,15 \pm 0,08$ & $0,04 \pm 0,01$ & $a \neq b \neq c$ \\
\hline vapA & $2,76 \pm 0,27$ & $6,16 \pm 1,58$ & $3,57 \pm 0,74$ & $\begin{array}{l}a \neq b \\
b \neq c\end{array}$ \\
\hline $\operatorname{cag} E$ & $0,00 \pm 0,00$ & $0,00 \pm 0,00$ & $1,18 \pm 0,08$ & $\begin{array}{l}a \neq c \\
b \neq c\end{array}$ \\
\hline отр29 & $0,00 \pm 0,00$ & $1,25 \pm 0,49$ & $23,54 \pm 1,12$ & $a \neq b \neq c$ \\
\hline$p g A$ & $3,81 \pm 2,12$ & $23,94 \pm 5,56$ & $2,09 \pm 0,65$ & $\begin{array}{l}a \neq b \\
b \neq c\end{array}$ \\
\hline
\end{tabular}


Tabela 6- Valores médios e desvio padrão de dois ensaios independentes realizados em triplicata de cada um dos genes normalizados em relação à transcrição de gapdH das três amostras de A. actinomycetemcomitans na condição controle sem célula epitelial após 24 hs de incubação (Média \pm Desvio padrão). Teste Anova-Tukey. AS (ausência de diferença estatisticamente significante entre amostras).

\begin{tabular}{|c|c|c|c|c|}
\hline \multirow{2}{*}{ Gene } & \multicolumn{4}{|c|}{ Amostra } \\
\hline & $\begin{array}{c}\text { ATCC } 29523 \\
\text { (a) }\end{array}$ & $\begin{array}{l}\text { SUNY } 465 \\
\text { (b) }\end{array}$ & $\begin{array}{l}\text { JP2 } \\
\text { (c) }\end{array}$ & $\begin{array}{c}\text { Diferença significante } \\
\mathbf{p}<0,05\end{array}$ \\
\hline$f l p$ & $0,002 \pm 0,0005$ & $0,10 \pm 0,003$ & $0,53 \pm 0,25$ & $a \neq b \neq c$ \\
\hline aae & $0,004 \pm 0,001$ & $2,07 \pm 0,19$ & $0,42 \pm 0,09$ & $a \neq b \neq c$ \\
\hline apaH & $0,003 \pm 0,002$ & $0,53 \pm 0,09$ & $0,62 \pm 0,19$ & $\begin{array}{l}a \neq b \\
a \neq c\end{array}$ \\
\hline omp100 & $0,017 \pm 0,007$ & $0,16 \pm 0,02$ & $0,37 \pm 0,046$ & $a \neq b \neq c$ \\
\hline$e m a A$ & $0,00 \pm 0,00$ & $0,11 \pm 0,031$ & $0,09 \pm 0,01$ & $\begin{array}{l}a \neq b \\
a \neq c\end{array}$ \\
\hline$l t x$ & $0,004 \pm 0,002$ & $0,56 \pm 0,15$ & $3,88 \pm 1,92$ & $\mathrm{a} \neq \mathrm{b} \neq \mathrm{c}$ \\
\hline$c d t B$ & $0,004 \pm 0,001$ & $4,98 \pm 0,90$ & $4,75 \pm 0,69$ & $\begin{array}{l}a \neq b \\
a \neq c\end{array}$ \\
\hline$v p p A$ & $0,008 \pm 0,008$ & $10,75 \pm 1,87$ & $7,08 \pm 0,71$ & $\begin{array}{l}a \neq b \\
a \neq c\end{array}$ \\
\hline orf859 & $0,00 \pm 0,00$ & $0,10 \pm 0,02$ & $0,07 \pm 0,005$ & $\begin{array}{l}a \neq b \\
a \neq c\end{array}$ \\
\hline vapA & $0,04 \pm 0,0005$ & $5,80 \pm 0,88$ & $8,07 \pm 1,85$ & $\begin{array}{l}a \neq b \\
a \neq c\end{array}$ \\
\hline $\operatorname{cag} E$ & $0,00 \pm 0,00$ & $0,07 \pm 0,03$ & $0,15 \pm 0,04$ & $\begin{array}{l}a \neq b \\
a \neq c\end{array}$ \\
\hline omp29 & $0,00 \pm 0,00$ & $5,54 \pm 1,77$ & $171,14 \pm 23,16$ & $a \neq b \neq c$ \\
\hline$p g A$ & $0,15 \pm 0,13$ & $0,66 \pm 0,14$ & $1,03 \pm 0,12$ & $a \neq c$ \\
\hline
\end{tabular}


Tabela 7- Valores médios e desvio padrão de dois ensaios independentes realizados em triplicata de cada um dos genes normalizados em relação à transcrição de gapdH das três amostras de A. actinomycetemcomitans após adesão em 24 hs de incubação (Média \pm Desvio padrão). Teste Anova-Tukey. AS (ausência de diferença estatisticamente significante entre amostras).

\begin{tabular}{|c|c|c|c|c|}
\hline \multirow{2}{*}{ Gene } & \multicolumn{4}{|c|}{ Amostra } \\
\hline & $\begin{array}{c}\text { ATCC } 29523 \\
\text { (a) }\end{array}$ & $\begin{array}{l}\text { SUNY } 465 \\
\text { (b) }\end{array}$ & $\begin{array}{c}\text { JP2 } \\
\text { (c) }\end{array}$ & $\begin{array}{c}\text { Diferença significante } \\
\mathbf{p}<0,05\end{array}$ \\
\hline$f l p$ & $50,41 \pm 18,66$ & $0,068 \pm 0,02$ & $1,95 \pm 0,57$ & $\mathrm{a} \neq \mathrm{b} \neq \mathrm{c}$ \\
\hline aae & $19,23 \pm 4,58$ & $0,96 \pm 0,31$ & $0,65 \pm 0,27$ & $\begin{array}{l}a \neq b \\
a \neq c\end{array}$ \\
\hline apaH & $8,74 \pm 1,43$ & $0,00 \pm 0,00$ & $0,47 \pm 0,24$ & $\mathrm{a} \neq \mathrm{b} \neq \mathrm{c}$ \\
\hline omp100 & $0,08 \pm 0,01$ & $1,99 \pm 0,53$ & $0,25 \pm 0,014$ & $\mathrm{a} \neq \mathrm{b} \neq \mathrm{c}$ \\
\hline$e m a A$ & $0,0006 \pm 0,0005$ & $0,06 \pm 0,02$ & $0,23 \pm 0,006$ & $\begin{array}{l}a \neq b \\
a \neq c\end{array}$ \\
\hline$l t x$ & $0,125 \pm 0,06$ & $2,54 \pm 0,41$ & $2,06 \pm 0,53$ & $\begin{array}{l}a \neq b \\
a \neq c\end{array}$ \\
\hline$c d t B$ & $68,09 \pm 21,18$ & $1,56 \pm 0,75$ & $4,21 \pm 1,37$ & $a \neq b \neq c$ \\
\hline$v p p A$ & $71,49 \pm 10,66$ & $2,04 \pm 1,15$ & $3,94 \pm 1,11$ & $\begin{array}{l}a \neq b \\
a \neq c\end{array}$ \\
\hline orf859 & $0,39 \pm 0,10$ & $0,06 \pm 0,004$ & $0,03 \pm 0,02$ & $\begin{array}{l}a \neq b \\
a \neq c\end{array}$ \\
\hline vapA & $29,73 \pm 3,44$ & $8,46 \pm 1,51$ & $3,66 \pm 0,58$ & $\mathrm{a} \neq \mathrm{b} \neq \mathrm{c}$ \\
\hline $\operatorname{cag} E$ & $0,00 \pm 0,00$ & $0,12 \pm 0,07$ & $0,07 \pm 0,02$ & $\begin{array}{l}a \neq b \\
a \neq c\end{array}$ \\
\hline omp29 & $0,00 \pm 0,00$ & $0,33 \pm 0,28$ & $46,40 \pm 16,10$ & $\begin{array}{l}a \neq b \\
b \neq c\end{array}$ \\
\hline$p g A$ & $43,39 \pm 3,98$ & $24,19 \pm 2,21$ & $2,43 \pm 0,26$ & $\mathrm{a} \neq \mathrm{b} \neq \mathrm{c}$ \\
\hline
\end{tabular}


A

B
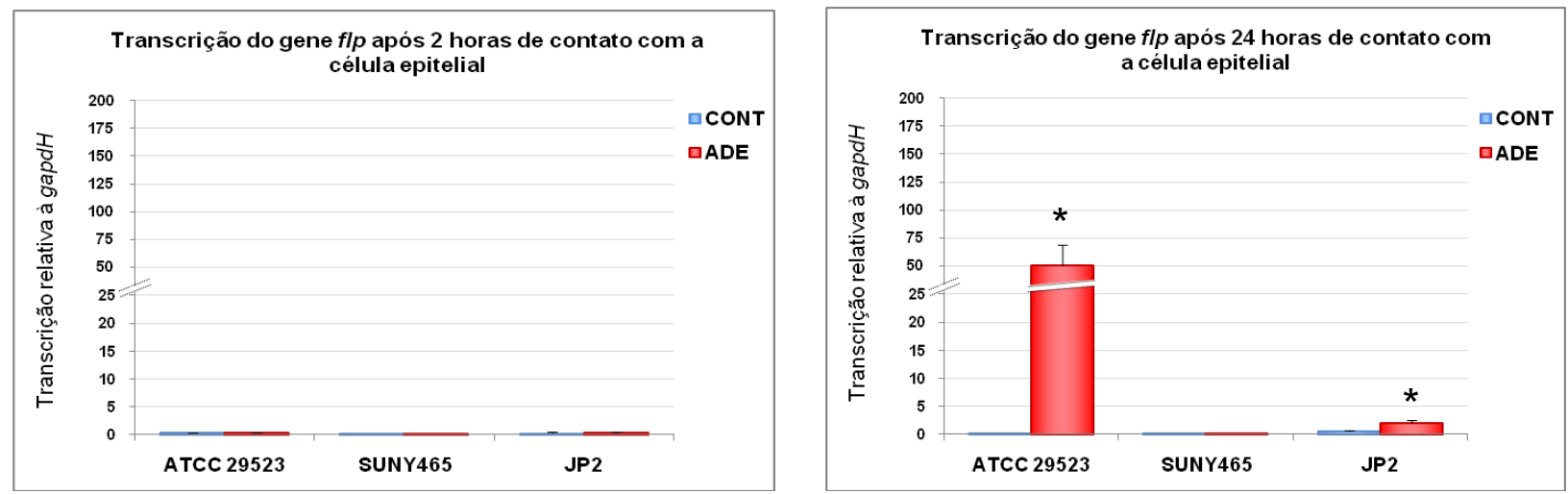

Figura 3- Transcrição gênica relativa do gene $f l p$ no ensaio controle (sem a presença da célula epitelial gengival OBA-9) e após adesão a célula epitelial gengival em 2 horas (A) e 24 horas (B). Teste Anova-Tukey, diferença estatisticamente significante em relação ao controle foi considerada quando $* \mathrm{p}<0,05$.

A

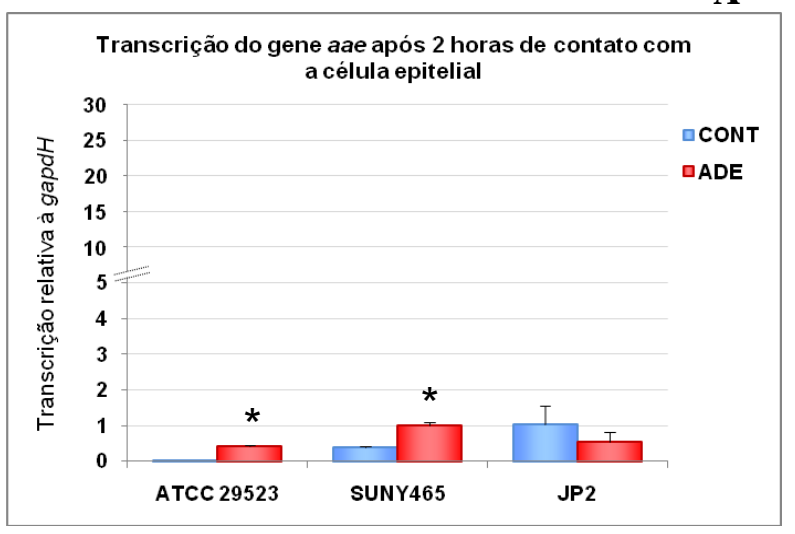

B

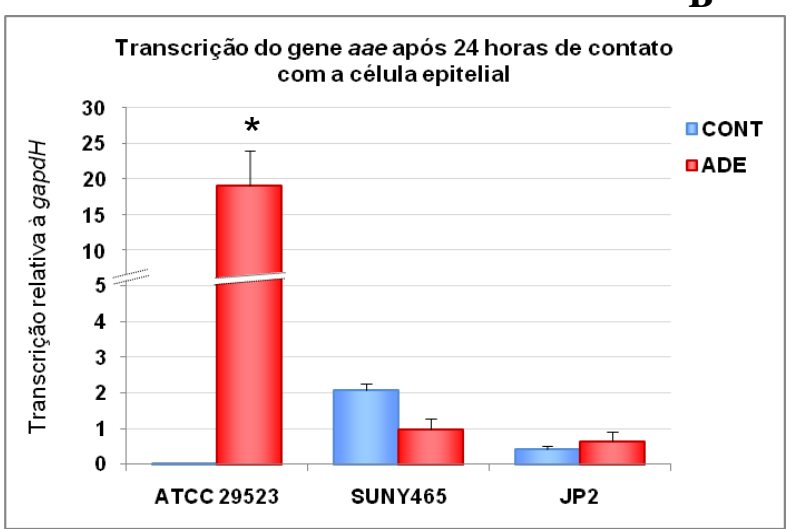

Figura 4- Transcrição gênica relativa do gene aae no ensaio controle (sem a presença da célula epitelial gengival OBA-9) e após adesão a célula epitelial gengival em 2 horas (A) e 24 horas (B). Teste Anova-Tukey, diferença estatisticamente significante em relação ao controle foi considerada quando $* \mathrm{p}<0,05$. 
$\mathbf{A}$
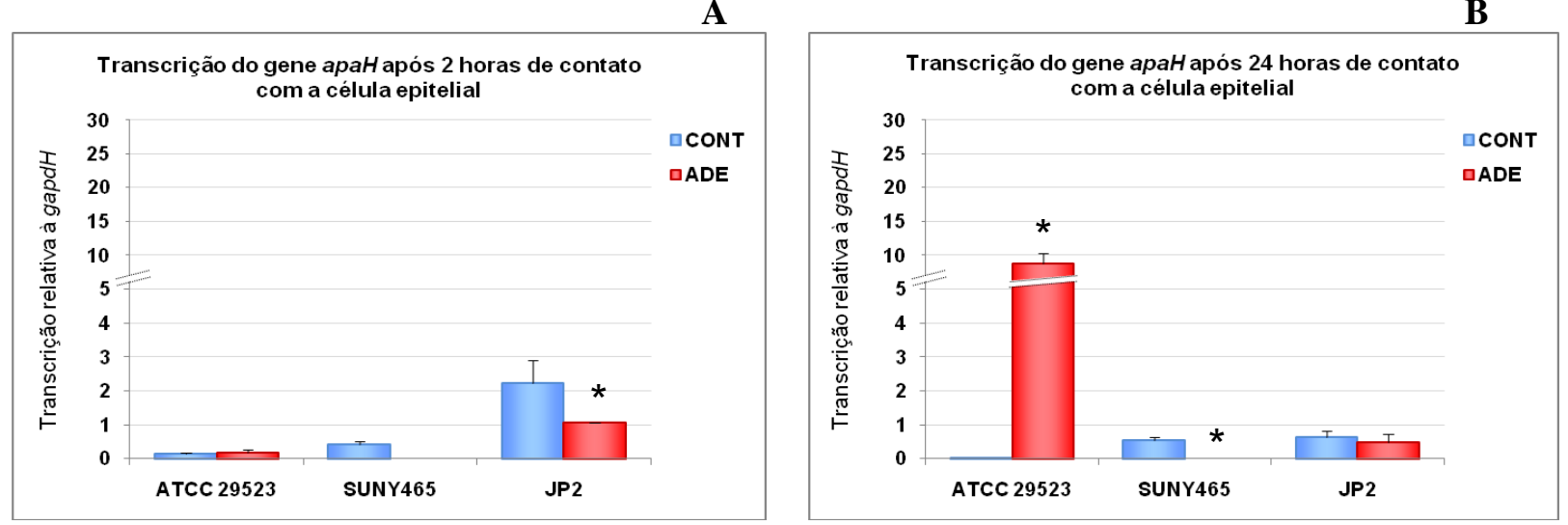

Figura 5- Transcrição gênica relativa do gene $a p a H$ no ensaio controle (sem a presença da célula epitelial gengival OBA-9) e após adesão a célula epitelial gengival em 2 horas (A) e 24 horas (B). Teste Anova-Tukey, diferença estatisticamente significante em relação ao controle foi considerada quando $* \mathrm{p}<0,05$.

A

B
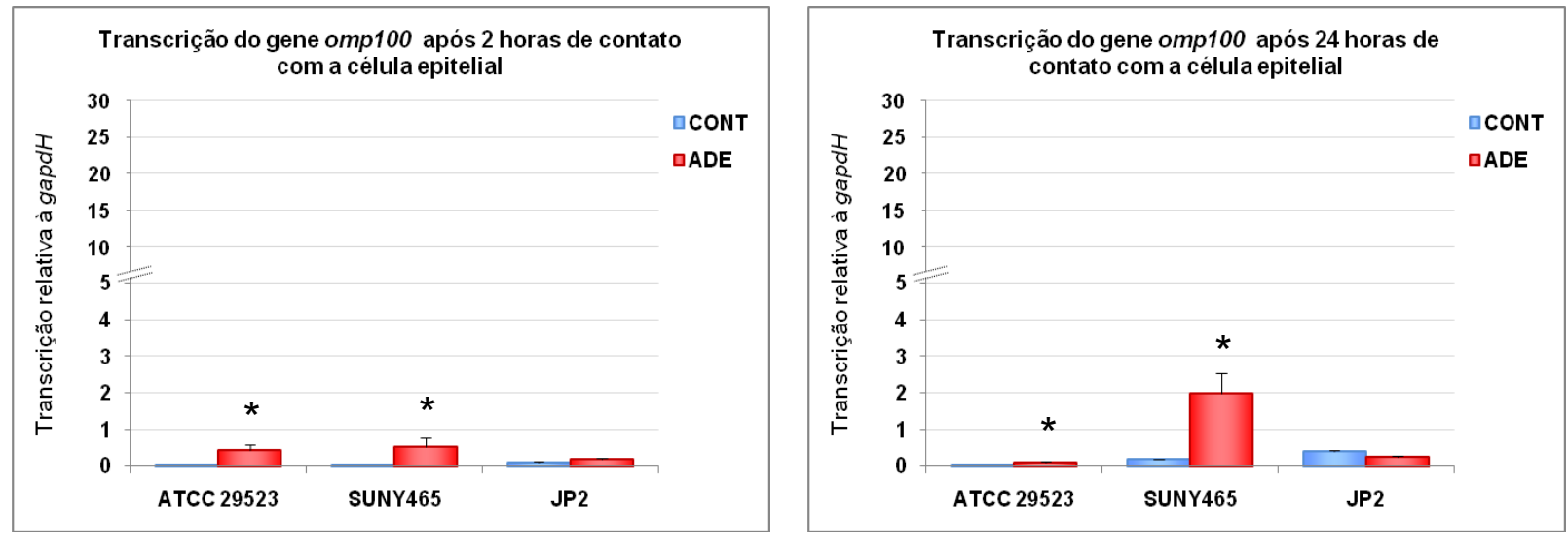

Figura 6- Transcrição gênica relativa do gene omp100 no ensaio controle (sem a presença da célula epitelial gengival OBA-9) e após adesão a célula epitelial gengival em 2 horas (A) e 24 horas (B). Teste Anova-Tukey, diferença estatisticamente significante em relação ao controle foi considerada quando $* \mathrm{p}<0,05$. 

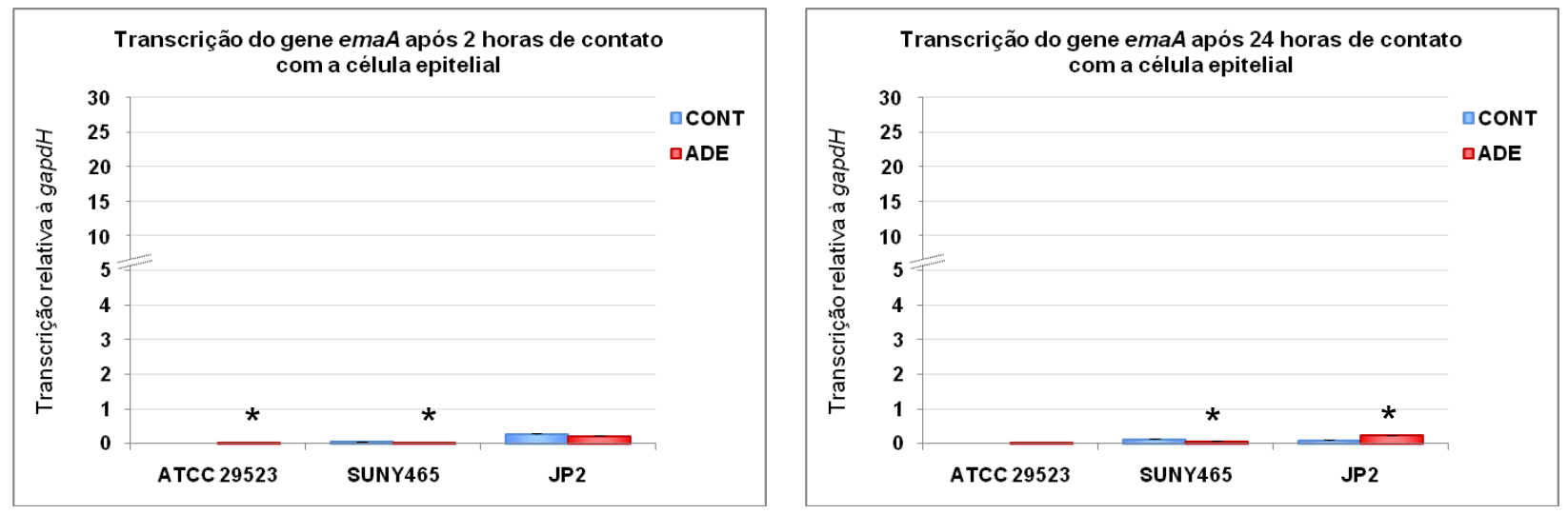

Figura 7- Transcrição gênica relativa do gene emaA no ensaio controle (sem a presença da célula epitelial gengival OBA-9) e após adesão a célula epitelial gengival em 2 horas (A) e 24 horas (B). Teste Anova-Tukey, diferença estatisticamente significante em relação ao controle foi considerada quando $* \mathrm{p}<0,05$.

A

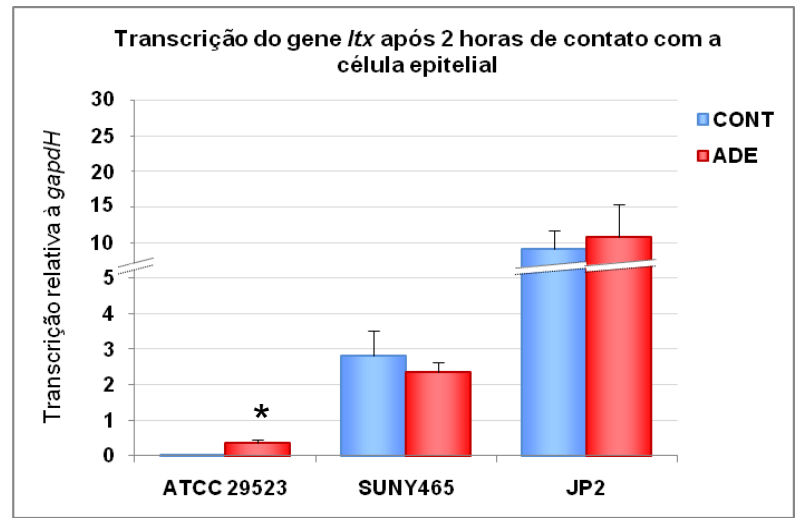

B

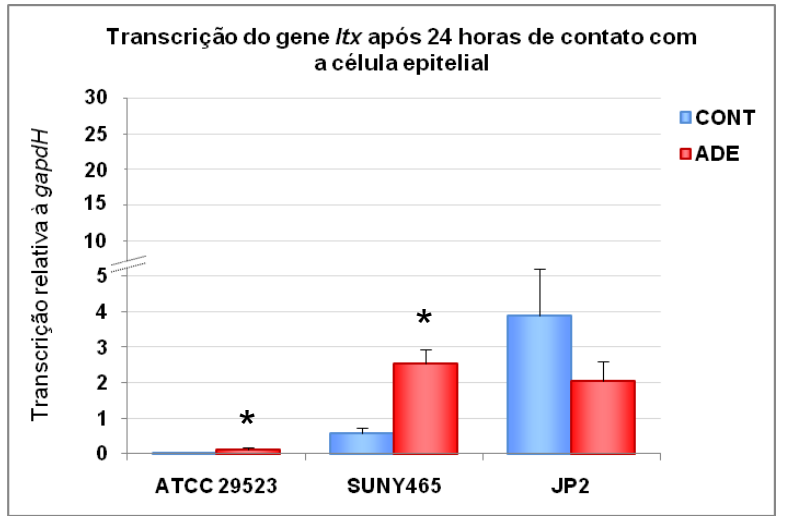

Figura 8- Transcrição gênica relativa do gene ltx no ensaio controle (sem a presença da célula epitelial gengival OBA-9) e após adesão a célula epitelial gengival em 2 horas (A) e 24 horas (B). Teste Anova-Tukey, diferença estatisticamente significante em relação ao controle foi considerada quando $* \mathrm{p}<0,05$. 
A

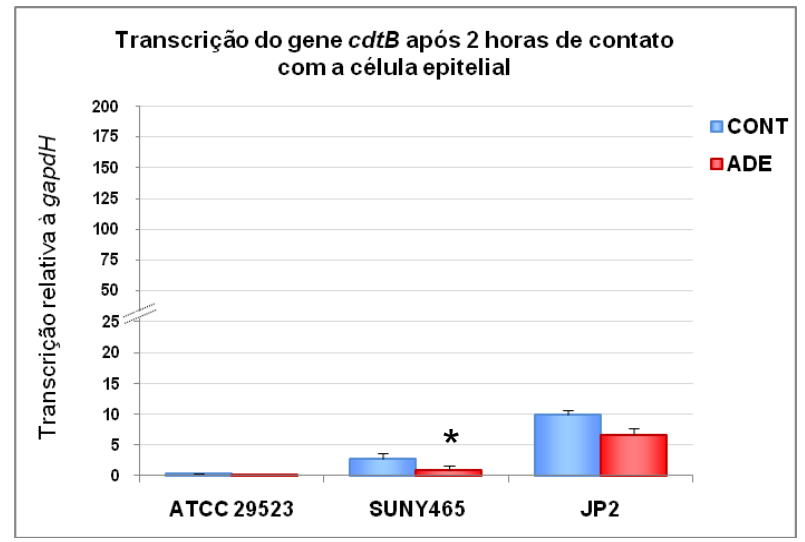

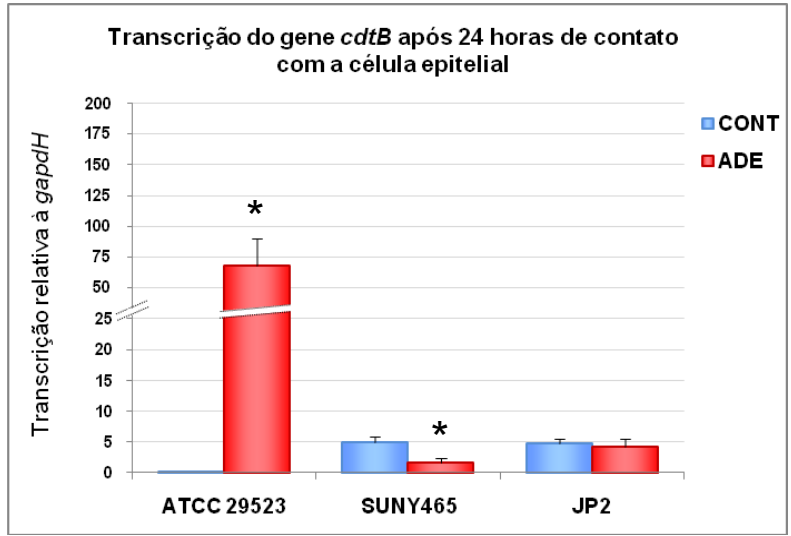

Figura 9- Transcrição gênica relativa do gene $c d t B$ após no ensaio controle (sem a presença da célula epitelial gengival OBA-9) e após adesão a célula epitelial gengival em 2 horas (A) e 24 horas (B). Teste Anova-Tukey, diferença estatisticamente significante em relação ao controle foi considerada quando $* \mathrm{p}<0,05$.

A

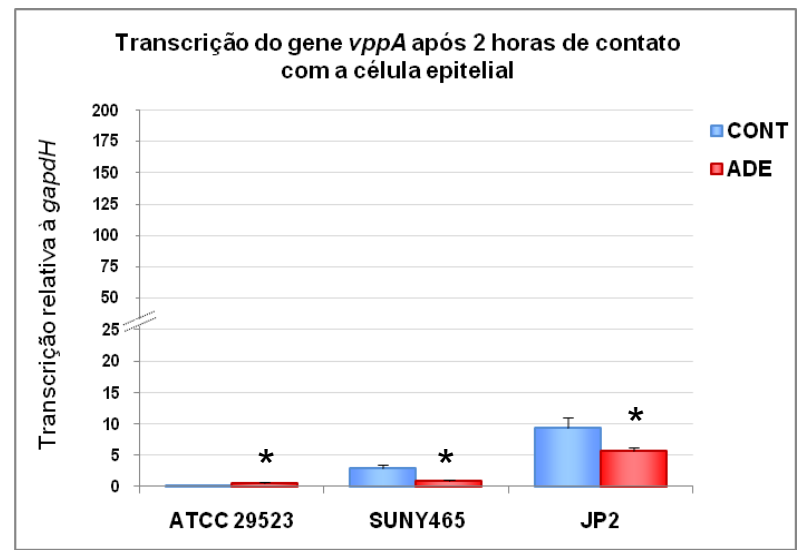

B

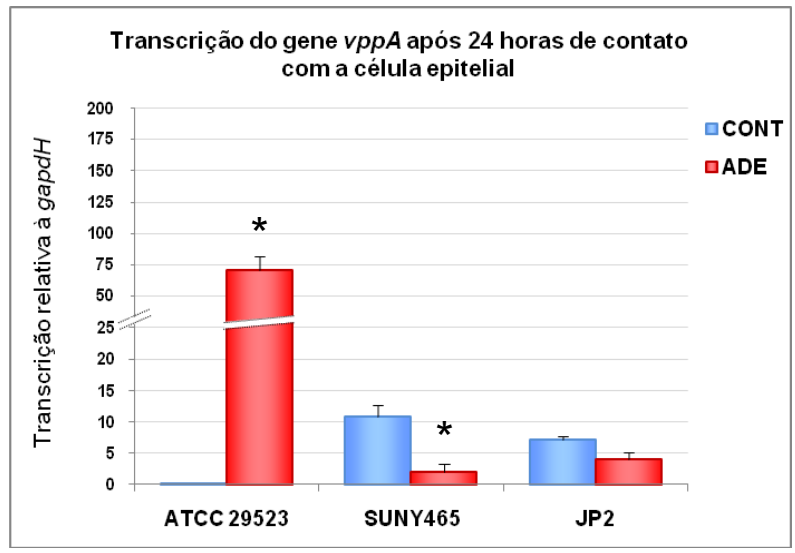

Figura 10- Transcrição gênica relativa do gene $v p p A$ no ensaio controle (sem a presença da célula epitelial gengival OBA-9) e após adesão a célula epitelial gengival em 2 horas (A) e 24 horas (B). Teste Anova-Tukey, diferença estatisticamente significante em relação ao controle foi considerada quando $* \mathrm{p}<0,05$. 
A

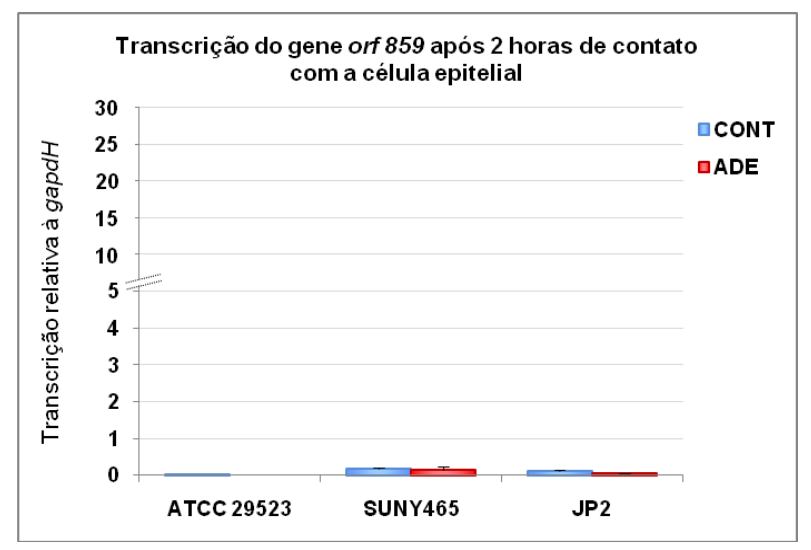

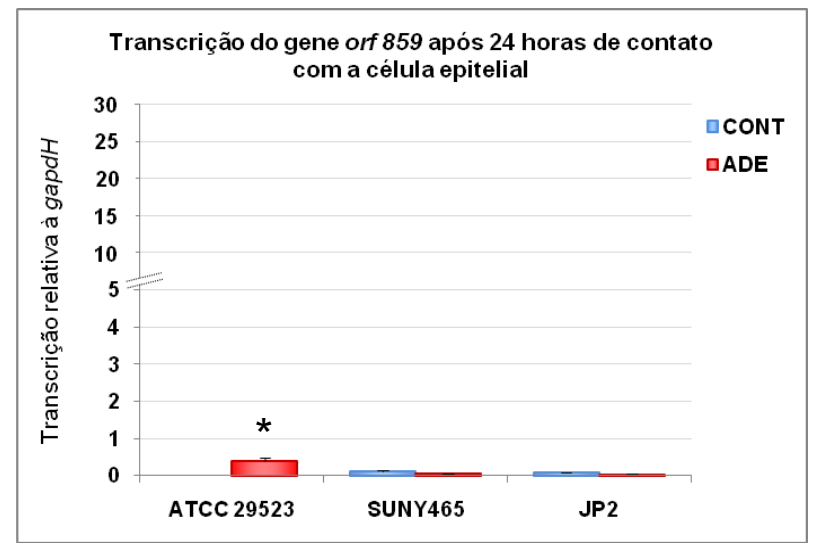

Figura 11- Transcrição gênica relativa do gene orf859 no ensaio controle (sem a presença da célula epitelial gengival OBA-9) e após adesão a célula epitelial gengival em 2 horas (A) e 24 horas (B). Teste Anova-Tukey, diferença estatisticamente significante em relação ao controle foi considerada quando $* \mathrm{p}<0,05$.

A

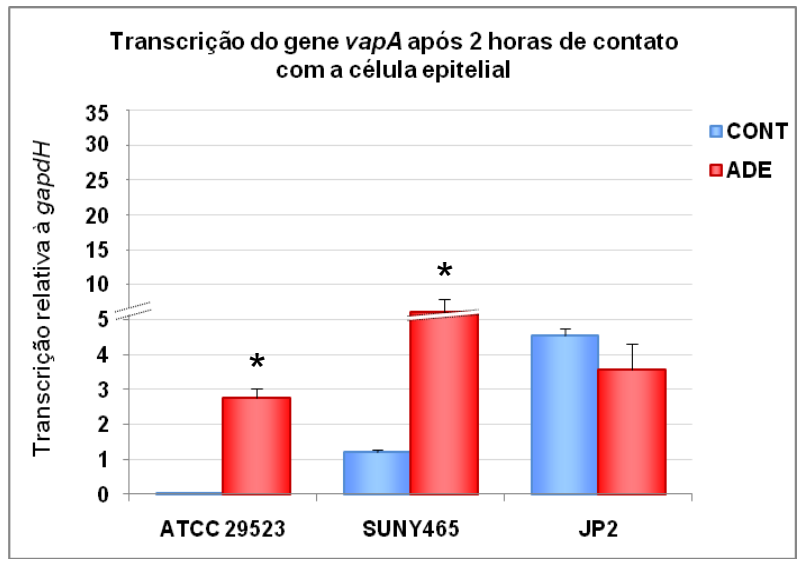

A

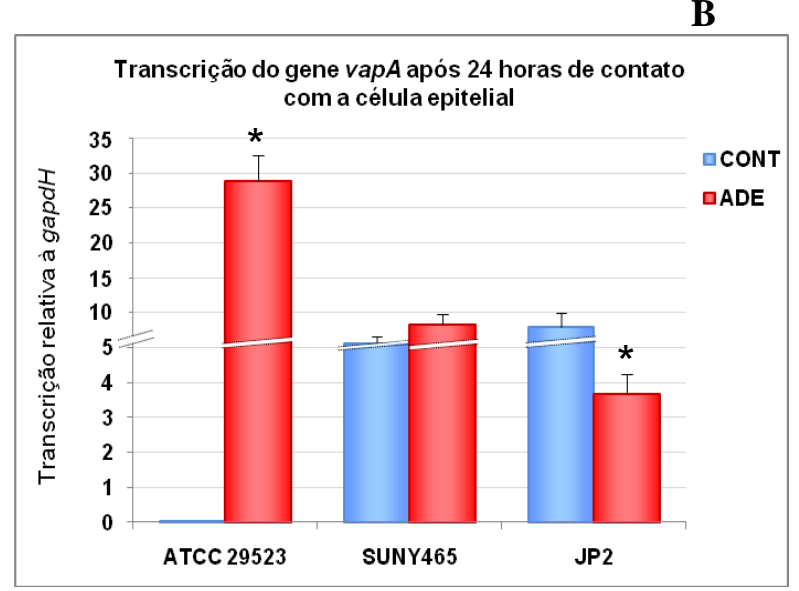

Figura 12- Transcrição gênica relativa do gene vapA no ensaio controle (sem a presença da célula epitelial gengival OBA-9) e após adesão a célula epitelial gengival em 2 horas (A) e 24 horas (B). Teste Anova-Tukey, diferença estatisticamente significante em relação ao controle foi considerada quando $* \mathrm{p}<0,05$. 
A

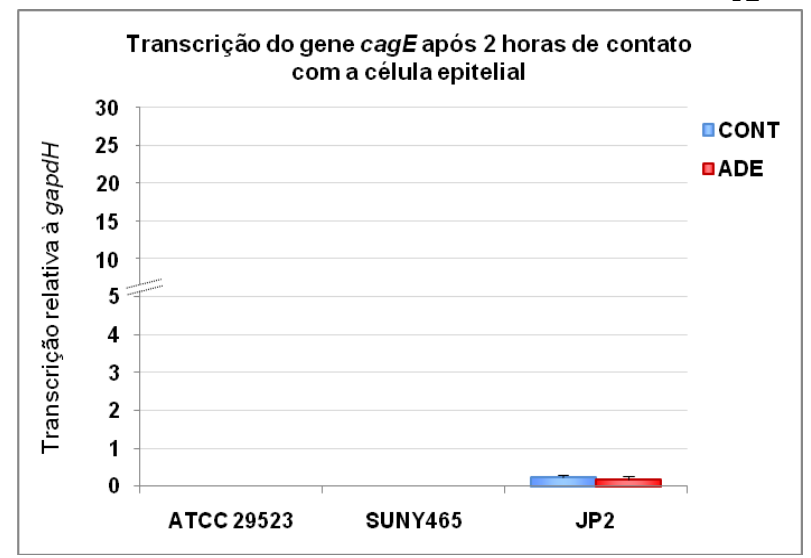

B

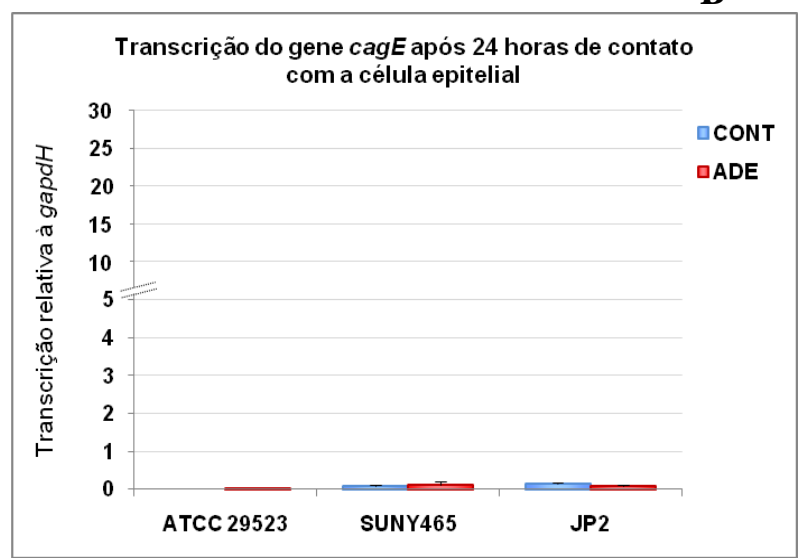

Figura 13- Transcrição gênica relativa do gene $\operatorname{cag} E$ no ensaio controle (sem a presença da célula epitelial gengival OBA-9) e após adesão a célula epitelial gengival em 2 horas (A) e 24 horas (B). Teste Anova-Tukey, diferença estatisticamente significante em relação ao controle foi considerada quando $* \mathrm{p}<0,05$.

A

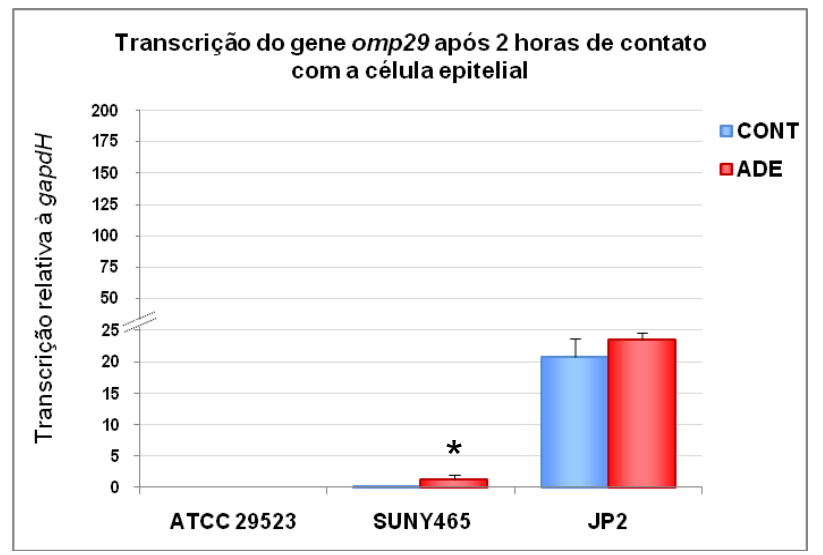

B

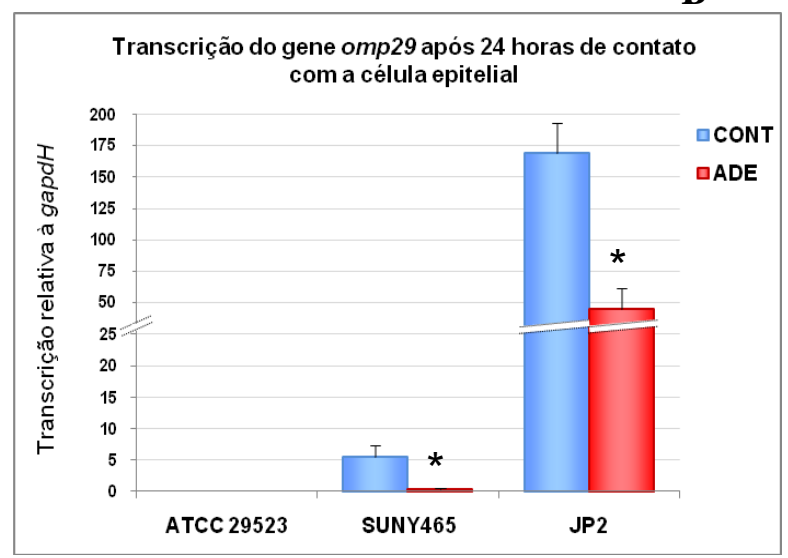

Figura 14- Transcrição gênica relativa do gene omp29 no ensaio controle (sem a presença da célula epitelial gengival OBA-9) e após adesão a célula epitelial gengival em 2 horas (A) e 24 horas (B). Teste Anova-Tukey, diferença estatisticamente significante em relação ao controle foi considerada quando $* \mathrm{p}<0,05$. 
A

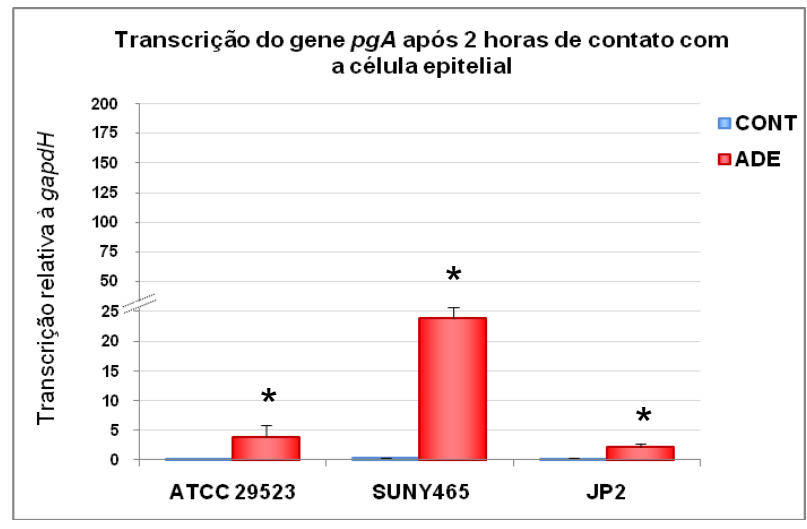

B

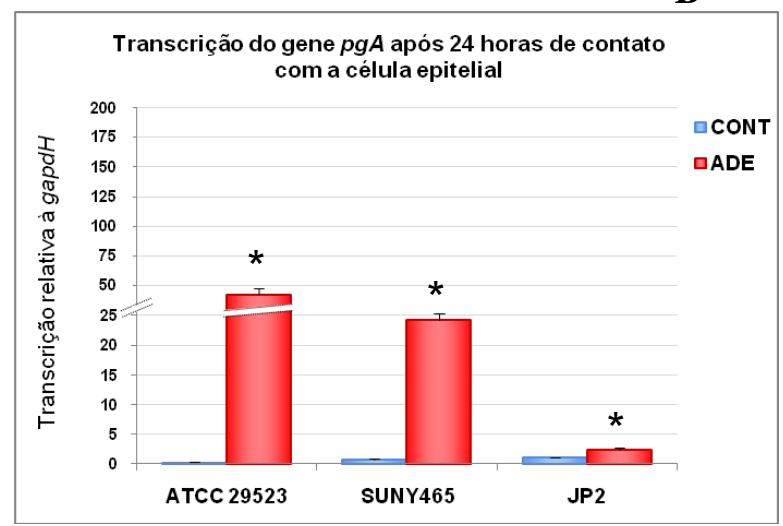

Figura 15- Transcrição gênica relativa do gene $p g A$ no ensaio controle (sem a presença da célula epitelial gengival OBA-9) e após adesão a célula epitelial gengival em 2 horas (A) e 24 horas (B). Teste Anova-Tukey, diferença estatisticamente significante em relação ao controle foi considerada quando $* \mathrm{p}<0,05$.

A transcrição de $e m a A$ foi regulada positivamente após 2 horas de interação com células epiteliais pela cepa ATCC 29523 ou em 24 h por JP2 (Figura 7). Esta adesina liga-se a colágeno, e quando em ensaio piloto foi adicionado colágeno para recobrir os poços de microplaca, a expressão de emaA aumentou ainda mais (dados não demonstrados).

Quanto à expressão da toxina $c d t B$, a amostra JP2 apresentou níveis de transcrição superiores às demais amostras no intervalo de 2 horas de infecção (Figura 9A), mas após 24 horas de interação a células epiteliais, o nível de transcrição de $c d t B$ da amostra ATCC29523 superou o valor demonstrado pela amostra JP2 (Figura 9B). Pode ser observado que a transcrição de $c d t B$ foi paralela à transcrição do gene vppA (Figuras 9 e 10), o que seria esperado, visto que estes genes são codificados em um mesmo operon (MAYER et al., 1999; SHENKER et al., 2000).

Como é possível observar nas Figuras 8 (A e B), 14 (A e B) e tabelas 4 a 7, a amostra JP2 apresentou níveis de transcrição superiores aos observados nas amostras SUNY 465 e ATCC29523, para os genes ltx e omp29. É importante ressaltar que a variabilidade de transcrição foi observada não somente entre amostras de sorotipos distintos (JP2 e ATCC 29523, sorotipos b e a respectivamente), mas também entre amostras pertencentes ao mesmo sorotipo (JP2 e SUNY 
465, ambas sorotipo b). Deve ser ainda observado que a transcrição de $o m p 29$ foi maior no meio de cultura sem célula após 24 h de exposição do que no mesmo meio após 2 h (controle 2 h) para as amostras SUNY 465 e JP2, particularmente para esta última, sugerindo que a fase da cultura foi responsável pela regulação. Por outro lado, a adição de células ao meio promoveu redução da transcrição relativa de omp29 para as amostras SUNY 465 e JP2 após 24 h, enquanto a expressão relativa de omp29 foi regulada positivamente após a infecção de SUNY465 por 2 h em célula epitelial.

O gene orf 859, que codifica uma proteína associada à sobrevivência intracelular (HANDFIELD et al., 2005), apresentou baixo nível de transcrição no intervalo de 2 horas de infecção para as amostras SUNY e JP2, não sendo transcrito pela amostra ATCC 29523 neste intervalo. No entanto, após 24 horas de infecção em células epiteliais, este gene foi regulado positivamente para a amostra ATCC 29523, superando o nível de transcrição das demais amostras, como demonstrado nas Figuras 11A e B.

O gene vapA foi regulado positivamente na amostra SUNY 465 após adesão em células epiteliais, com nível de transcrição superior às demais, no intervalo de 2 horas. Após 24 horas de infecção em células epiteliais, a amostra ATCC 29523 superou o nível de transcrição na adesão, com uma ressalva de que, este aumento no nível de transcrição não foi acompanhado pela condição controle (sem presença da célula epitelial), diferindo das demais amostras (Figuras 12 $A$ e B).

O gene $\operatorname{cag} E$ foi transcrito apenas por JP2 no intervalo de 2 horas de infecção, e após 24 horas a amostra SUNY também apresentou transcrição a baixos níveis, não apresentando diferenças na transcrição entre o controle e o ensaio após adesão a célula epitelial (Figuras 13A e B). Por outro lado, a amostra ATCC 29523 não apresentou transcrição deste gene em nenhuma das condições analisadas neste estudo.

O gene que codifica a biossíntese de polissacarídeo extracelular, denominado pgA, principal componente da matriz do biofilme de A. actinomycetemcomitans, foi transcrito a níveis muito baixos nos controles sem adição de células, e apresentou regulação positiva para todas as amostras após 2 h e 24 h de interação com a célula epitelial gengival, sendo que os maiores níveis de transcritos foram observados após 24 horas de interação (Figuras 15A e B). 


\subsection{Adesão e Invasão de Aggregatibacter actinomycetemcomitans JP2 à célula epitelial OBA- 9 em diferentes intervalos de tempo}

Antes da realização dos ensaios de expressão gênica da célula epitelial gengival OBA-9 após interação com as células de A. actinomycetemcomitans, foi determinada a capacidade de adesão e invasão da cepa JP2. A eficiência máxima de adesão de A. actinomycetemcomitans JP2 a células epiteliais foi atingida após 2 horas de infecção, sendo a amostra JP2 aderente em todos os intervalos de tempo e persistindo até 24 horas, como demonstrado na Figura 16. Além disso, esta amostra mostrou-se viável após tratamento com gentamicina, indicando a localização intracelular em todos os intervalos de tempo testados após interação com células epiteliais OBA9, como demonstrado na Figura 17.

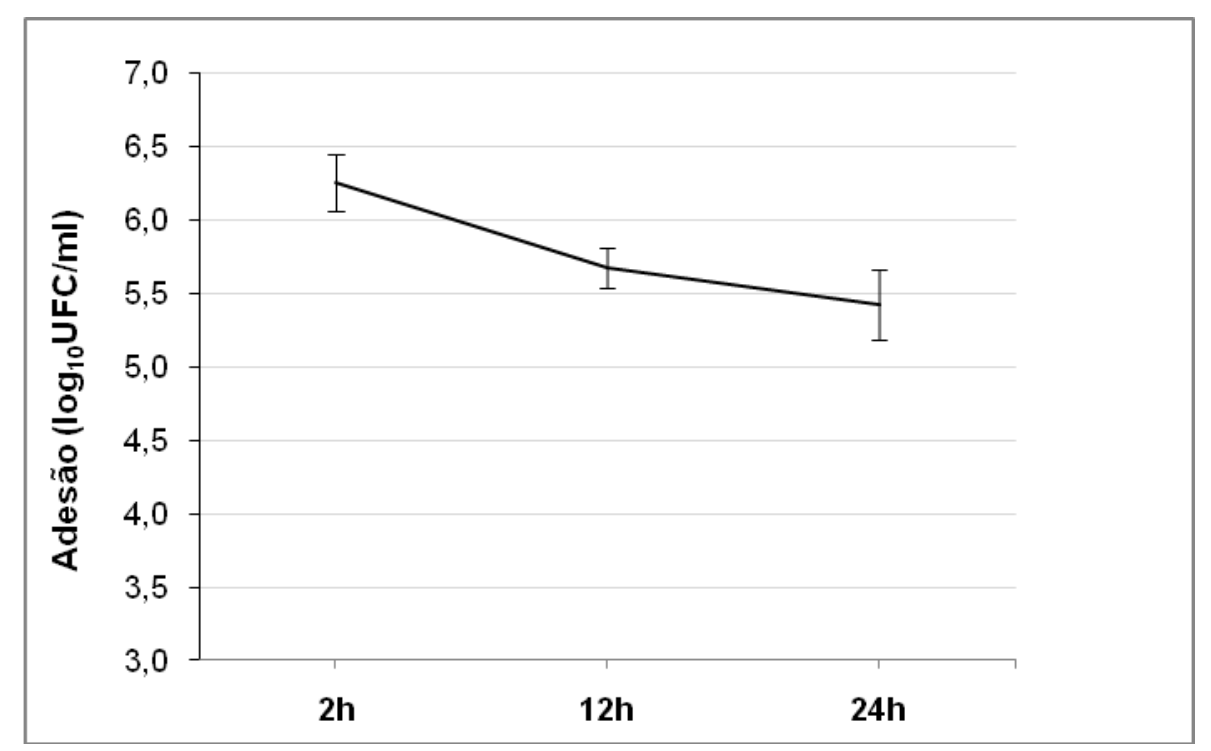

Figura 16- Número de células bacterianas ( $\left.\log _{10} \mathrm{UFC} / \mathrm{ml}\right)$ recuperadas após ensaio de adesão em célula epitelial gengival (OBA-9) utilizando a cepa Aggregatibacter actinomycetemcomitans JP2 após 2, 12 e 24 horas de infecção. Resultados em triplicata de três ensaios independentes. 


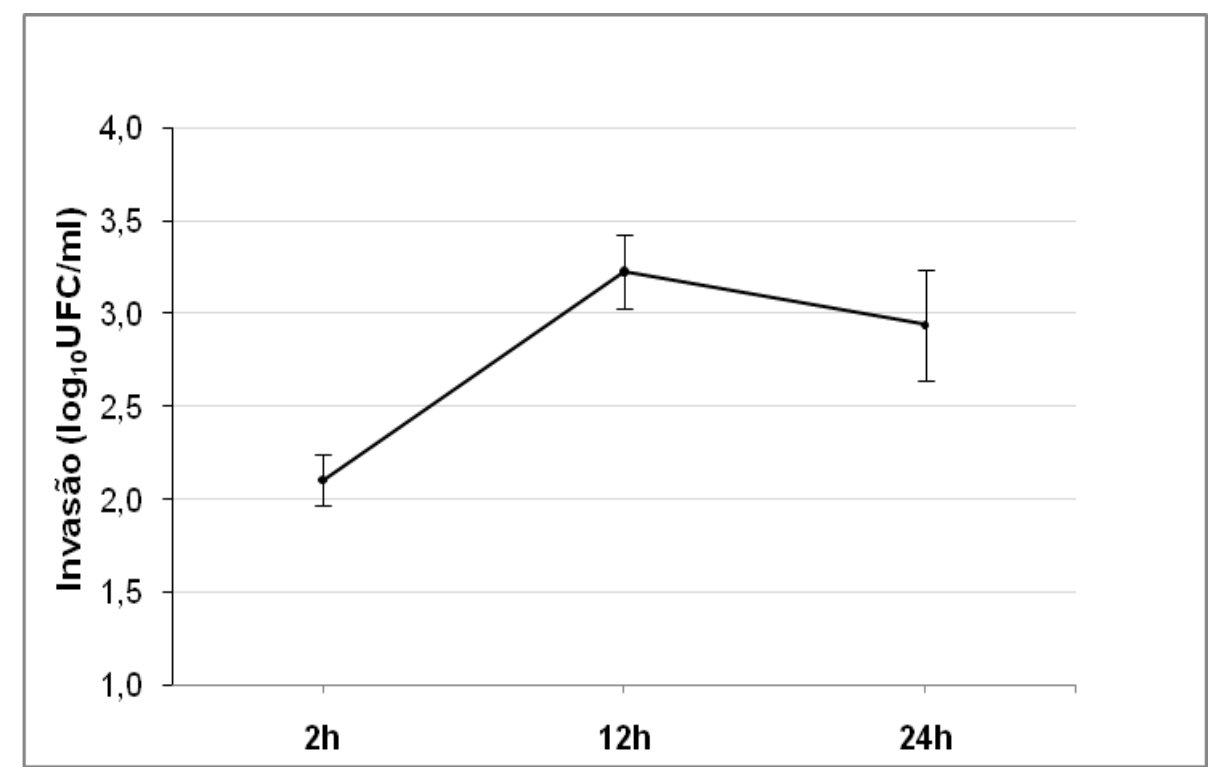

Figura 17- Número de células bacterianas recuperadas $\left(\log _{10} \mathrm{UFC} / \mathrm{ml}\right)$ após ensaio de invasão em célula epitelial gengival (OBA-9) utilizando a cepa Aggregatibacter actinomycetemcomitans JP2 após 2, 12 e 24 horas de infecção. Resultados em triplicata de três ensaios independentes.

\subsection{Análise da expressão gênica da célula epitelial OBA-9 após 24 horas de infecção com JP2}

$\mathrm{Na}$ análise da expressão gênica da via de transdução de sinais pela célula epitelial gengival OBA-9, após 24 horas de infecção com a cepa JP2 de A. actinomycetemcomitans, 15 genes foram regulados positivamente em relação ao controle sem a presença da bactéria, como apresentado na Tabela 8. Estas diferenças foram estatisticamente significantes (Teste $\mathrm{T}$ de Student, $\mathrm{p}<0,01)$. No total 15 vias diferentes foram estimuladas após a interação com a bactéria: NFkB, mitogênica, Wnt, TGF $\beta$, PI3 kinase, p53, stress, CREB, Jak-Stat, estrógeno, andrógeno, cálcio, proteína quinase $\mathrm{C}$, fosfolipase $\mathrm{C}$ e LDL.

O gene que codifica o fator de estimulação de colônias de granulócitos e macrófagos (CSF2), também denominado GM-CSF, foi o mais estimulado (170 vezes), como demonstrado na Tabela 8. O segundo gene mais estimulado, foi o que codifica TNF- $\alpha$ (28,93 vezes), sendo este um importante mediador inflamatório, responsável pela ativação da cascata de sinalização do NF-kB. Outro gene relacionado a ativação de NF-kB transcrito positivamente após a infecção 
por A. actinomycetemcomitans foi IL-1 (4 vezes). Os genes estimulados neste estudo pertencentes à via NF-kB foram: CCL20, ICAM1, VCAM1, BIRC3.

O terceiro gene mais estimulado, foi o gene que codifica a proteína EGR1 (resposta de crescimento precoce) (14,08 vezes), um fator de transcrição envolvido na regulação de genes envolvidos na inflamação, coagulação, imunidade adaptativa e inata (PRITCHARD et al., 2007). 
Tabela 8- Proteínas cujos genes codificadores foram regulados positivamente na via de transdução de sinais da célula epitelial gengival OBA-9, após 24 horas de infecção com a amostra JP2 em relação ao controle sem a presença da bactéria. Teste $\mathrm{T}$ de Student foi empregado para comparar os níveis de transcritos nas células não infectadas (controle) e após a infecção. Valores de $\mathrm{p}<0,01$ foram considerados significantes.

\begin{tabular}{|c|c|c|c|c|}
\hline $\begin{array}{l}\text { Símbolo } \\
\text { da } \\
\text { Proteína }\end{array}$ & Proteína codificada & $\begin{array}{c}\text { Número de } \\
\text { acesso } \\
\text { Gen Bank }\end{array}$ & $\begin{array}{l}\text { Variação } \\
\text { em vezes }\end{array}$ & Valor de $p$ \\
\hline BIRC3 & $\begin{array}{l}\text { Protéina Baculoviral contendo sequências } \\
\text { repetidas IAP } 3\end{array}$ & NM_001165 & 5,92 & 0,000022 \\
\hline CCL2 & Quimiocina (C-C motif) ligante 2 & NM_002982 & 12,18 & 0,000003 \\
\hline CCL20 & Quimiocina (C-C motif) ligante 20 & NM_004591 & 6,49 & 0,0012 \\
\hline CDKN1A & Inibidor quinase ciclina dependente $1 \mathrm{~A}$ & NM_000389 & 4,88 & 0,0015 \\
\hline CSF2 & Fator estimulador de colônias 2 & NM_000758 & 170,04 & 0,00002 \\
\hline EGR1 & Resposta de crescimento precoce 1 & NM_001964 & 14,08 & 0,00066 \\
\hline FOS & $\begin{array}{l}\text { Homólogo ao oncogene murino de } \\
\text { osteossarcoma viral V-fos FBJ }\end{array}$ & NM_005252 & 4,47 & 0,004 \\
\hline GADD45A & $\begin{array}{l}\text { Fator de Interrupção de crescimento e indutor } \\
\text { de dano no DNA, alfa }\end{array}$ & NM_001924 & 8,00 & 0,00058 \\
\hline GREB1 & Proteína GREB-1 & NM_014668 & 10,13 & 0,0088 \\
\hline ICAM-1 & Molécula de adesão intercelular 1 (CD54), & NM_000201 & 7,67 & 0,00003 \\
\hline $\mathrm{IL} 1 \alpha$ & Interleucina 1 , alfa & NM_000575 & 4,01 & 0,0009 \\
\hline IRF1 & Fator regulador de Interferon 1 & NM_002198 & 5,39 & 0,004 \\
\hline JUN & Jun oncogene & NM_002228 & 7,16 & 0,00023 \\
\hline TNF & $\begin{array}{l}\text { Fator de Necrose tumoral (Superfamília TNF, } \\
\text { membro 2) }\end{array}$ & NM_000594 & 28,93 & 0,0097 \\
\hline VEGFA & Fator de crescimento de endotélio vascular A & NM_003376 & 4,59 & 0,000246 \\
\hline
\end{tabular}




\subsection{Detecção de GM-CSF/CSF2, TNF- $\alpha$ e ICAM-1 no sobrenadante de culturas celulares.}

Foram realizados ensaios imunoenzimáticos para determinação dos níveis de GMCSF/CSF2, TNF- $\alpha$ e ICAM-1, no sobrenadante de culturas de células OBA-09, infectadas por $A$. actinomycetemcomitans JP2 e controle (sem infecção), visto que os genes que codificam esses fatores foram regulados positivamente nas células OBA-09 infectadas por $A$. actinomycetemcomitans JP2, após 24 horas de infecção.

Os resultados mostraram que houve produção de CSF2/GM-CSF por células epiteliais OBA-9 após infecção por A. actinomycetecomitans JP2 conforme ilustrado na Figura 18A, enquanto não foram observados níveis detectáveis desta citocina no sobrenadante de células não infectadas.

Foi determinada maior produção de TNF- $\alpha$ pelas células OBA-09 quando infectadas por A. actinomycetemcomitans cepa JP2, atingindo a concentração de 2.859,96 pg/ml após 24 horas de interação, do que pelas células controle não infectadas, como demonstrado na Figura 18B. Deve ser considerado que esta diferença poderia ser ainda maior, visto que ocorre degradação desta citocina no meio de cultura durante a incubação, mesmo sem a adição da bactéria, conforme demonstrado na Figura 19.

Também foi observada maior produção da molécula de adesão ICAM-1 pelas células infectadas, atingindo a concentração de $60 \mathrm{pg} / \mathrm{ml}$ após interação com a bactéria por 24 hs, do que pelas células OBA-09 não infectadas, como ilustrado na Figura 18C. Assim, a análise funcional confirmou as observações determinadas nos ensaios de transcrição gênica. 
A

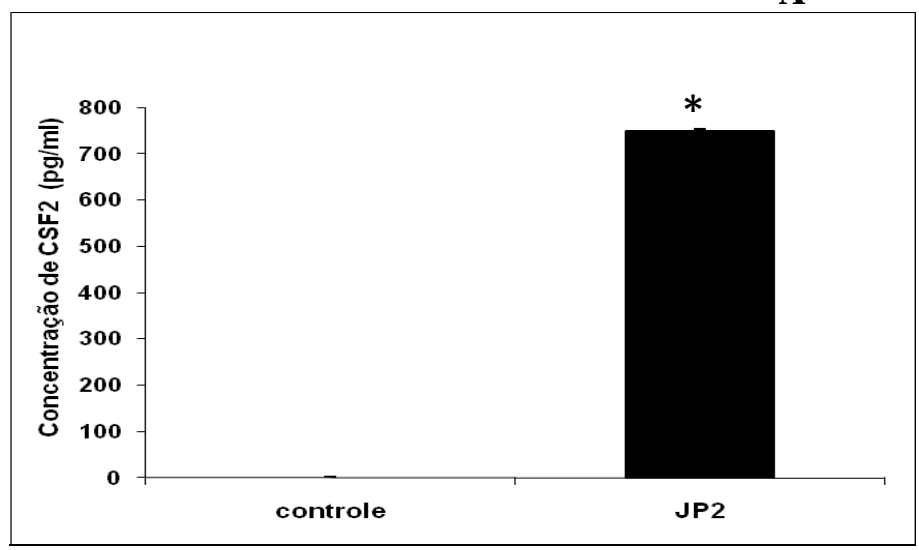

B

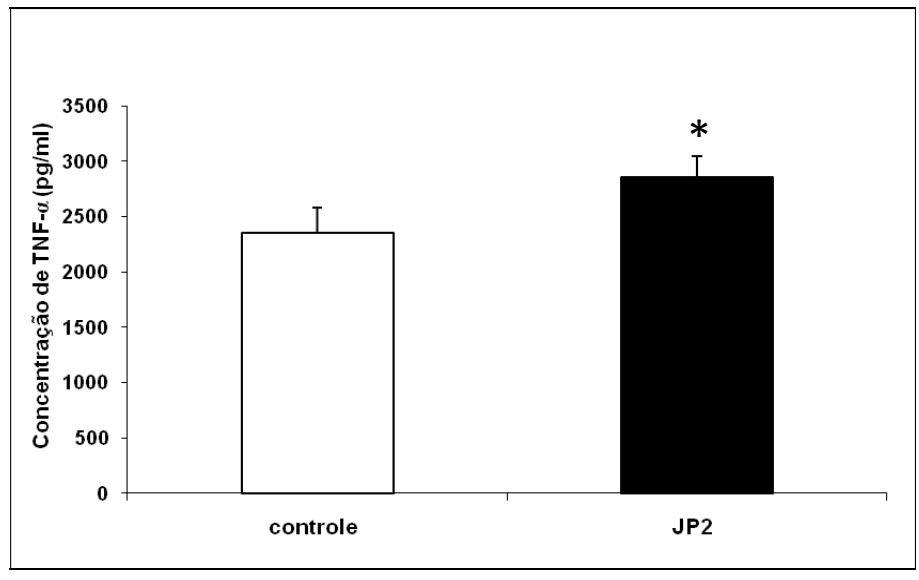

C

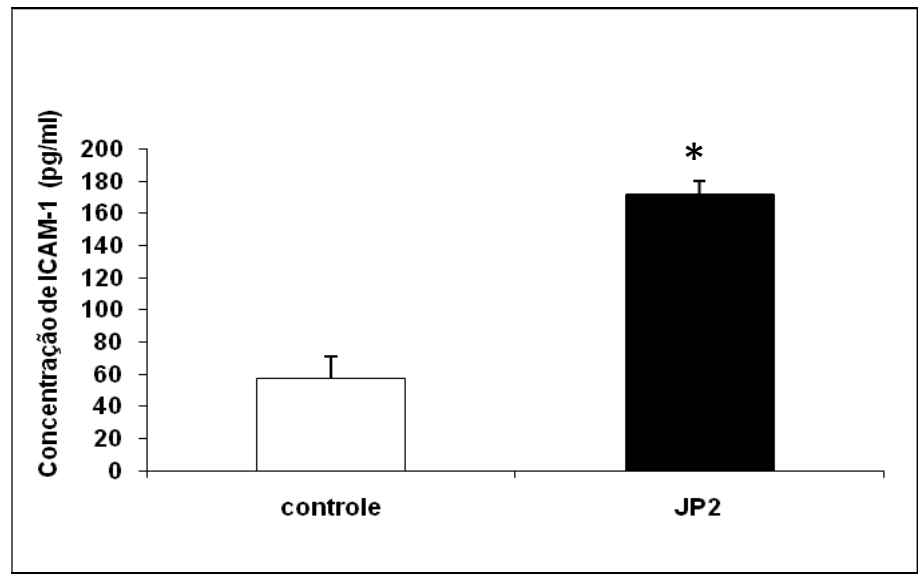

Figura 18- Níveis de mediadores inflamatórios (CSF-2 - em A, TNF- $\alpha$ em B e ICAM-1 em C) determinados por ELISA no sobrenadante de células epiteliais gengivais OBA-9 após 24 horas de infecção com a amostra A. actinomycetemcomitans JP2 a uma MOI de 1:100. Controle: células epiteliais sem adição da bactéria. Teste $\mathrm{t}$ de Student, diferença estatisticamente significante foi considerada quando, ${ }^{*} \mathrm{p}<0,05$. 


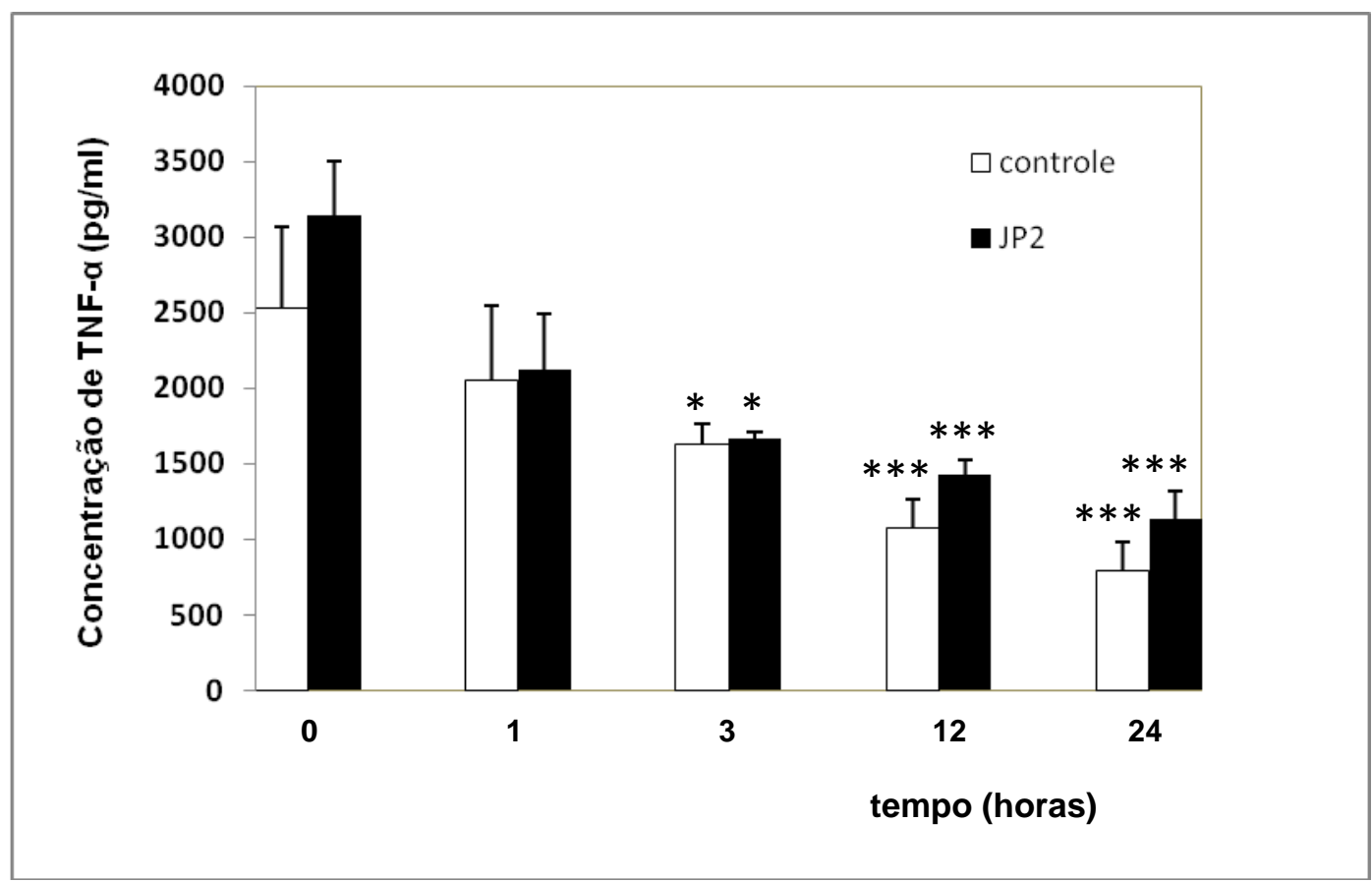

Figura 19- Níveis de TNF- $\alpha$ determinados por ELISA em meio de cultura adicionado de $2.000 \mathrm{pg} / \mathrm{ml}$ de TNF- $\alpha$, seguindo-se incubação por diferentes intervalos de tempo. Controle - apenas o meio de cultura [KFSM (Invitrogen)] contendo TNF- $\alpha$. JP2 - meio de cultura contendo TNF- $\alpha$ e inoculado com $3 \times 10^{7} \mathrm{UFC} A$. actinomycetemcomitans JP2/ml. Diferenças estatisticamente significantes (ANOVA, * $\mathrm{p}<0,05 ; * * \mathrm{p}<0,01 ; * * * \mathrm{p}<0,001$ ) em relação ao controle sem incubação (tempo 0 horas). 


\subsection{Detecção de GM-CSF/CSF2, TNF- $\alpha$ e ICAM-1 em amostras de tecido gengival de indivíduos saudáveis e pacientes com periodontite (agressiva e crônica)}

Os níveis dos mediadores inflamatórios GM-CSF/CSF2, TNF- $\alpha$ e ICAM-1 também foram analisados em amostras de tecido gengival obtidas de pacientes com diferentes condições periodontais.

Foram analisadas amostras de tecido gengival de indivíduos periodontalmente saudáveis $(n=12)$, com periodontite agressiva $(n=10)$ e periodontite crônica $(n=11)$. A distribuição da concentração dos mediadores nos tecidos está apresentada na figura 20. Os dados obtidos para cada amostra de tecido gengival estão apresentados no anexo B. Foi possível observar altas concentrações dos três mediadores inflamatórios analisados [GM-CSF/CSF2 (Figura 20A), TNF$\alpha$ (Figura 20B) e ICAM-1 (Figura 20C)] tanto em amostras de pacientes com periodontite agressiva como crônica. Os valores de mediana das concentrações em $\mathrm{ng} / \mathrm{ml}$ encontradas nas amostras de tecido gengival dos pacientes apresentando as diferentes condições periodontais estão descritas na Tabela 9. O teste de Kruskall-Wallis demonstrou que as diferenças nas concentrações de cada um dos mediadores foram estatisticamente significantes entre as biópsias de pacientes com periodontite (crônica e agressiva) e controles com periodonto saudável $(\mathrm{p}<0,05)$. 
Tabela 9- Valores da mediana das concentrações de GM-CSF/CSF2, TNF- $\alpha$ e ICAM-1 em ng/ml encontrados nas amostras de tecido gengival dos indivíduos periodontalmente saudáveis e pacientes apresentando periodontite agressiva e crônica.

\begin{tabular}{|c|c|c|c|}
\hline \multirow{2}{*}{$\begin{array}{c}\text { Mediador } \\
\text { inflamatório }\end{array}$} & \multicolumn{3}{|c|}{ Condição periodontal } \\
\hline & Periodontite Agressiva & Periodontite Crônica & Periodonto Saudável \\
\hline CSF2 & $10074,90 \mathrm{ng} / \mathrm{ml}$ & $4493,98 \mathrm{ng} / \mathrm{ml}$ & $0 \mathrm{ng} / \mathrm{ml}$ \\
\hline TNF- $\alpha$ & $6681,78 \mathrm{ng} / \mathrm{ml}$ & $5247,97 \mathrm{ng} / \mathrm{ml}$ & $0 \mathrm{ng} / \mathrm{ml}$ \\
\hline ICAM-1 & $618163,59 \mathrm{ng} / \mathrm{ml}$ & $611025,65 \mathrm{ng} / \mathrm{ml}$ & $37537,46 \mathrm{ng} / \mathrm{ml}$ \\
\hline
\end{tabular}




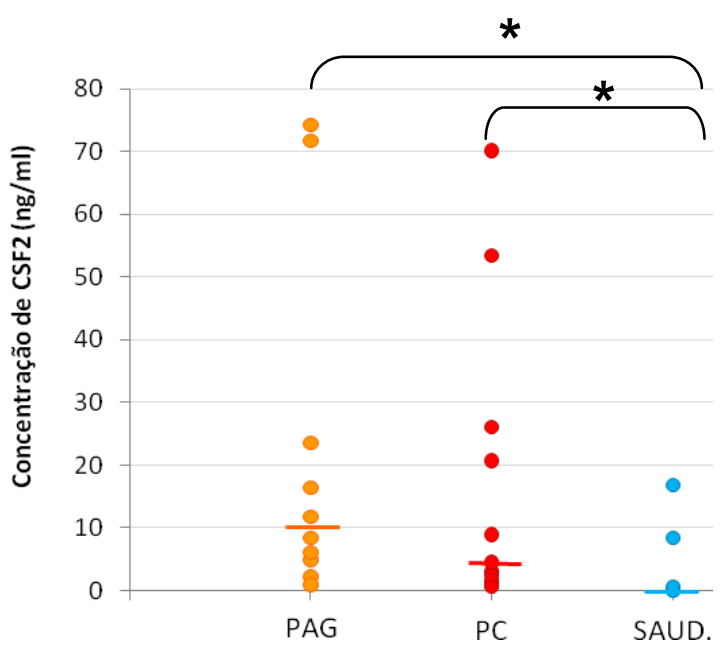

A

B
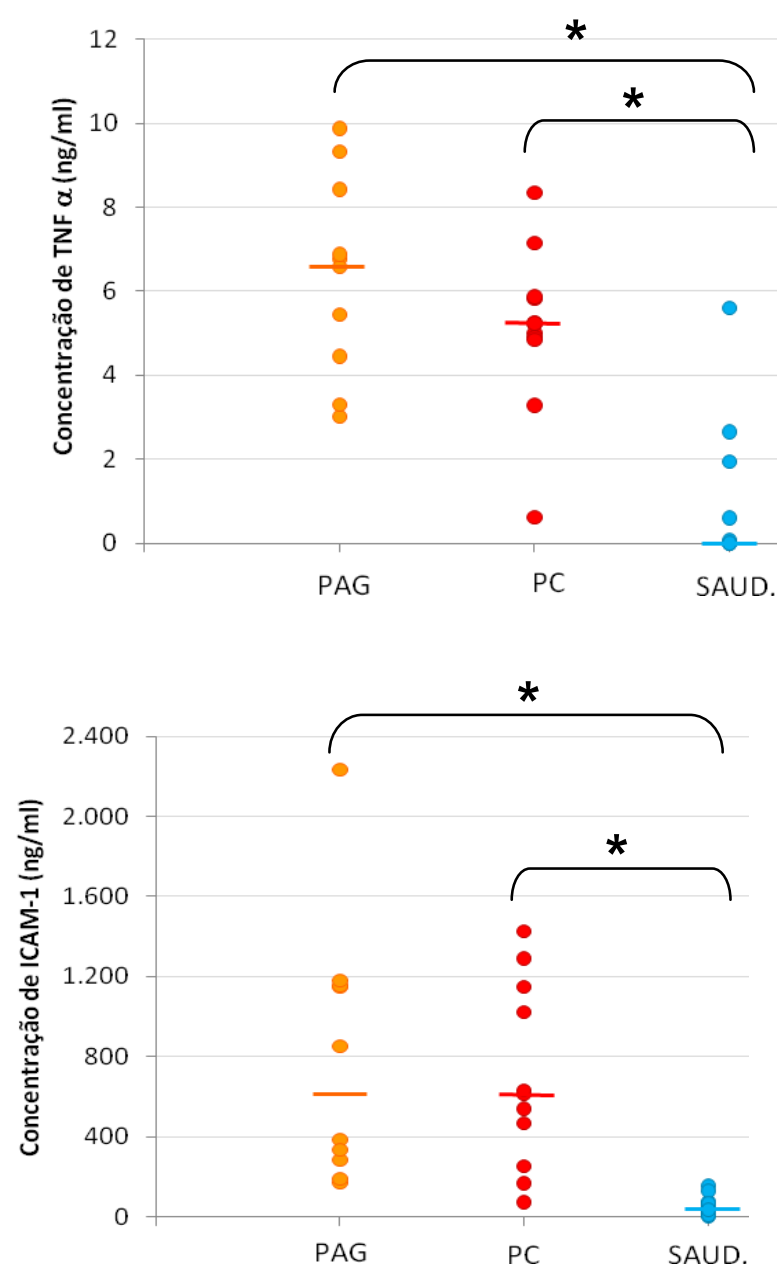

Figura 20- Distribuição dos níveis de mediadores inflamatórios (CSF-2 em A, TNF- $\alpha$ em B, ICAM-1 em C) determinados por ELISA em amostras de tecido gengival de pacientes com periodontite agressiva (PAG), periodontite crônica (PC) e indivíduos com periodonto saudável (SAUD). Teste de Kruskal-Wallis, diferença estatisticamente significante foi considerada quando, $* \mathrm{p}<0,05$. 


\section{DISCUSSÃO}

Bactérias apresentam sistemas de transdução de sinais altamente conservados na natureza que mediam adaptações a uma variedade de mudanças ambientais (GEORGELLIS et al., 2001). O epitélio é considerado a primeira barreira física encontrada por patógenos (ESKAN et al., 2008a) e no processo da infecção, a expressão gênica de bactérias pode ser alterada, procurando adaptar-se aos desafios oferecidos pelo novo ambiente. Assim, no presente estudo, visamos determinar se A. actinomycetemcomitans também sofre alterações na transcrição dos fatores de virulência após a interação com células epiteliais gengivais, e se esta regulação é cepadependente.

As amostras de A. actinomycetemcomitans utilizadas neste estudo para análise da transcrição gênica bacteriana foram ATCC29523 (sorotipo a), JP2 (sorotipo b, produtora de altos níves de leucotoxina) e SUNY 465 (sorotipo b). Foram observadas diferenças na eficiência de adesão às células epiteliais entre as amostras, mas todas foram capazes de aderir e foi determinado o nível de transcrição das células aderidas. Observou-se que a capacidade de adesão foi maior para a cepa SUNY465; seguida pela cepa JP2 e a de menor eficiência de adesão foi a cepa ATCC 29523. Os dados estão de acordo com estudos anteriores, em que a capacidade de adesão a células epiteliais de origem tumoral (células KB) foi cerca de cinco vezes maior para a cepa SUNY 465 do que para a cepa ATCC 29523 (ROSE; MEYER; FIVES-TAYLOR, 2003).

A transcrição de genes que codificam fatores de virulência apresentou diferenças estatisticamente significantes entre as amostras analisadas, sendo que esta diferença também foi observada entre amostras pertencentes ao mesmo sorotipo (JP2 e SUNY 465, sorotipo b), sugerindo que a regulação gênica é cepa dependente. Por exemplo, houve diferença na expressão do gene ltx entre as amostras JP2 e SUNY 465, em que a amostra JP2 apresentou expressão superior em relação à SUNY 465, principalmente na condição controle, sem contato com célula epitelial (figura 8 e tabelas 4 e 6). A leucotoxina é um fator relacionado à evasão das defesas pela bactéria, e faz parte da família de toxinas RTX, de bactérias Gram negativas. $A$. actinomycetemcomitans exibe dois fenótipos distintos leucotóxicos: minimamente leucotóxico e altamente leucotóxico como a cepa JP2 (SPITZNAGEL, KRAIG; KOLODRUBETZ, 1991). A transcrição de ltx após cultivo in vitro é maior em linhagens JP2 (“JP2-like”) devido a diferenças 
na região do promotor ltx (BROGAN et al., 1994). A razão para a maior produção de leucotoxina pelas cepas JP2-like não é completamente entendida. A hipótese lógica seria que a região faltando na região promotora das cepas JP2-like ligar-se-ia a uma proteína regulatória que regularia a transcrição dos genes ltx. Outra alternativa seria que no promotor de ltx da cepa JP2 existe uma menor distância entre o sítio de ligação da polimerase e os genes estruturais e consequentemente ocorreriam maiores níveis de transcrição (KACHLANY, 2010).

Embora a linhagem JP2 seja relacionada com maior virulência (SPITZNAGEL; KRAIG; KOLODRUBETZ, 1991; BROGAN et al., 1994; BUENO; MAYER; DI RIENZO, 1998), as cepas minimamente leucotóxicas também são encontradas em pacientes com periodontite agressiva localizada (KAPLAN et al., 2002b; FINE et al., 2007; KAWAMOTO et al., 2009). Assim, Fine et al. (2007) questionam a hipótese de que a linhagem JP2 seja mais virulenta que as demais. Os dados apresentados neste estudo indicam que a transcrição de ltx pode ser regulada positivamente após contato com célula epitelial em amostras consideradas minimamente leucotóxicas, sendo que ocorreu regulação positiva da transcrição deste gene após contato com célula epitelial por 2 e 24 h para a amostra ATCC 29523, e após 24 h para SUNY 465 (Figuras 8A e B), sendo que esta última apresentou nível de transcrição superior à ATCC 29523. Na figura 8B e na tabela 7 pode ser observado ainda, que após 24 h de interação com células epiteliais, a transcrição de ltx foi semelhante entre as amostras JP2 e SUNY 465. Estes dados suportam a hipótese sugerida recentemente por Kachlany et al. (2010), de que cepas consideradas minimamente leucotóxicas sob condições de laboratório, poderiam produzir níveis similares de leucotoxina aos das cepas JP2-like em condições fisiológicas. Os níveis equivalentes de mRNA ltx produzidos por JP2 e SUNY465, mas não por ATCC29523, após interação com células epiteliais, sugerem que cepas do sorotipo b não JP2-like, consideradas de menor virulência apesar de associadas à periodontite agressiva, poderiam produzir altos níveis de leucotoxina in vivo. Esta hipótese deve ser confirmada analisando maior número de cepas de diferentes sorotipos após interacão com células, não somente na determinação do nível de transcritos de ltx, mas pela quantificação da leucotoxina produzida.

Por outro lado, o gene $c d t B$ que codifica a toxina distensora citoletal $(c d t)$, foi regulado negativamente após contato com a célula epitelial em ambas as cepas do sorotipo b, SUNY 465 e JP2, mas a sua transcrição foi inalterada em ATCC29523 no intervalo de 2 horas após contato 
com célula epitelial. Surprendentemente, foi observada uma regulação positiva de $c d t B$ após $24 \mathrm{~h}$ de interação com células na amostra ATCC 29523 (Figura 9B). O gene vppA situa-se a montante de $c d t$ também fazendo parte do operon cdt de A. actinomycetemcomitans (MAYER et al., 1999; SHENKER et al., 1999). Assim, os dados das figuras 9 e 10 mostram que a transcrição de vppA e $c d t$ ocorreu de maneira paralela em todas as amostras testadas, indicando que estes genes são regulados pelo mesmo promotor nestas amostras. Fabris et al. (2002) e Kawamoto et al. (2009) demonstraram que existem diferenças na atividade CDT entre diferentes amostras de $A$. actinomycetemcomtians. Nestes ensaios, foi obtido lisado de cultura de cada uma das amostras in vitro, e a atividade CDT demonstrada sobre células epiteliais. Os resultados do controle após 2 e 24 h, sem contato com células epiteliais são compatíveis com os dados dos níveis de mRNA de $c d t$ nas amostras JP2 e ATCC 29523, pois a primeira apresenta maior atividade CDT que a segunda. No entanto, estas diferenças podem não ser relevantes in vivo, pois após $24 \mathrm{~h}$ de interação com célula epitelial há indicação de maior expressão de CDT pela amostra ATCC 29523. Assim, para responder ao questionamento sobre diferenças na atividade CDT, deveriam ser analisadas células após a interação com o epitélio, portanto mais próximas das condições fisiológicas, e não culturas in vitro, como empregado em estudos anteriores (FABRIS et al., 2002; KAWAMOTO et al., 2009). Embora a associação da CDT com a patogênese ainda não seja totalmente esclarecida, esta toxina pode representar uma adaptação bacteriana, que poderia afetar a interação do microrganismo com o sistema imune do hospedeiro. Em estudo recente neste laboratório foi observado que os títulos de IgG sérica contra CDTA e CDTB não diferiram entre os indivíduos com diferentes condições periodontais. No entanto, títulos de IgG positivos para CDTC foram observados no soro de $100 \%$ dos indivíduos $\mathrm{PAgG}$, em apenas $8,3 \%$ dos soros de indivíduos PAgL, em nenhum indivíduo com periodontite crônica e em $25 \%$ dos saudáveis. As diferenças na resposta a CDTC e a OMP29 entre PAgG e PAgL poderiam indicar que CDT e OMP29 poderiam ser expressas diferentemente pelas cepas infectantes (ANDO et al., 2010). AaCDT modularia a resposta imune pela sua capacidade de induzir apoptose de células monocíticas não proliferativas e de linfócitos T (RABIN; FLITTON; DEMUTH, 2009; SHENKER et al., 2001). Em estudos realizados em nosso laboratório, demonstramos que a CDT em altas doses foi capaz de inibir a produção de NO (FERNANDES et al., 2008 ; ANDO et al., 2010). A inibição da produção de NO, favoreceria a persistência da infecção devido à menor atividade microbicida (ANDO et al., 2010). A observação que a amostra do sorotipo a testada 
induz a maiores níveis de transcrição de CDT após contato com célula epitelial deve ser confirmada por estudos funcionais. A associação do sorotipo a com indivíduos com periodonto saudável, poderia indicar que CDT não estaria ligada diretamente à destruição periodontal, mas à persistência da infecção nos tecidos do hospedeiro, uma hipótese que ainda necessita confirmação.

Outro fator modulatório determinante na expressão de alguns genes foi o tempo de interação com as células epiteliais. Por exemplo, na figura 3 (A e B) pode ser observado que o gene $f l p$ só foi transcrito a níveis detectáveis após 24 horas de infecção, mas não após 2 horas.

Foram observadas a ausência de transcrição de $f l p$, que codifica a subunidade fimbrial FLP, na condição controle e uma discreta transcrição nas demais condições testadas. Todas as amostras estudadas apresentaram morfologia colonial lisa. A conversão para o fenótipo liso, não fimbriado, não aderente pode ser resultado de mutações "frameshift", "nonsense" e "missense" em genes codificados no lócus tad, uma ilha de colonização encontrada em outras espécies bacterianas (TOMICHI et al., 2007). O fenótipo rugoso é fimbriado, autoagregativo, aderente a superficies abióticas, enquanto as variantes lisas são não fimbriadas, podem aderir-se às células epiteliais (ROSE; MEYER; FIVES-TAYLOR, 2003, YUE et al., 2007) e apresentam maior capacidade de invasão que as rugosas (MEYER et al., 1991). Assim, a ausência da transcrição de flp seria esperada nas condições analisadas, visto que as cepas testadas eram lisas, nas quais a ausência da produção da fímbria seria resultado de mutações (TOMICHI et al., 2007). No entanto, o gene flp foi transcrito após 24 horas de infecção nas amostras ATCC29523 e JP2. Contradizendo a hipótese de mutação no lócus tad das cepas lisas, estudos anteriores já mostraram que a expressão da fímbria exibe fases de transição, provocadas por fatores ambientais como pH, temperatura, oxigênio e concentração de ferro (SCANNAPIECO et al., 1987; WANG; LIU; CHEN, 2005; TOMICHI et al., 2007). Além disso, a conversão do fenótipo liso para rugoso associado à interação com células foi previamente descrita, sugerindo regulação positiva da transcrição de $f l p$ por cepas lisas após interação com células, como os dados aqui apresentados (MEYER e FIVES-TAYLOR, 1994). No entanto, no presente estudo foi observada a regulação positiva da transcrição de flp apenas em ATCC 29523 e JP2, após prolongada interação com célula epitelial, enquanto os dados de Meyer e Fives Taylor (1994) demonstraram variação de fenótipo liso para rugoso após interação com células pela cepa SUNY 465, mas não pelas cepas SUNY 75(S) e 652. Estudos adicionais sobre a expressão de fímbrias devem ser 
feitos, mas os dados sugerem que a transcrição de $f l p$ pode ser regulada positivamente em cepas lisas, possivelmente revertendo o fenótipo de liso para rugoso após prolongada exposição às células epiteliais. Esta regulação poderia ser explicada quando analisamos o ambiente subgengival. O epitélio, tanto no ambiente intra como extracelular poderia apresentar-se como um reservatório de células bacterianas, capazes de promover a recolonização da bolsa, após a remoção mecânica do biofilme. Assim, parte das células bacterianas não fimbriadas, oriundas do epitélio, poderiam tornar-se fimbriadas, exibindo assim, capacidade de aderir à superfície do dente e formar biofilme. A observação de que os isolados clínicos apresentam-se apenas como a variante rugosa (FINE et al., 1999) poderia ser decorrente do sítio de coleta, uma vez que apenas amostras obtidas de biofilme subgengival são analisadas.

O gene aae codifica a adesina termoestável autotransportada AAE, mas é discutível se essa adesina sofreria proteólise sendo secretada para o meio como outras proteínas autotransportadas ou se permanece ligada à célula (ROSE; MEYER; FIVES-TAYLOR, 2003). Esta adesina está envolvida na adesão às células epiteliais pela cepa ATCC 29523 e SUNY 465, pois mutantes defectivas em aae nestas amostras mostraram redução na eficiência de adesão a células epiteliais tumorais (KB) (ROSE; MEYER; FIVES-TAYLOR, 2003). O gene aae apresenta-se como único do operon e existe polimorfismo no número de repetições entre diferentes amostras (ROSE; MEYER; FIVES-TAYLOR, 2003). Foi recentemente descrito que o domínio envolvido na ligação das células epiteliais bucais localiza-se na região das repetições de Aae, embora tenha sido relatado outro domínio de ligação em Aae, reponsável pela ligação às células endoteliais (YUE; KAPLAN; FINE, 2009). A cepa SUNY 465 apresenta menor número de repetições que a cepa ATCC 29523, embora a primeira apresente maior eficiência de adesão que a segunda (ROSE; MEYER; FIVES-TAYLOR, 2003). Não foram observadas diferenças na transcrição relativa de aae entre as três cepas no controle, sendo que após $2 \mathrm{~h}$ de infecção houve aumento na transcrição de aae nas amostras ATCC 29523 e SUNY 465. Deve ser ressaltado que a regulação positiva mais significante de aae foi observada para a cepa ATCC 29523 após 24 h de interação com células epiteliais (figura 4B), como observado para o gene $f l p$, que codifica a fímbrilina (figura 3B). O mesmo padrão foi também observado para o gene apaH, em que os maiores níveis de transcritos foram observados em ATCC 29523 após 24 h de interação com células epiteliais. 
O gene apaH codifica uma diadenosina tetrafosfatase que cliva a "alarmôna" diadenosina tetrafosfato (Ap4A), uma classe de nucleosídeos associada à sinalização do tempo de divisão celular e participação na resposta ao estresse oxidativo (ISMAIL et al., 2003; ROSE; MEYER; FIVES-TAYLOR, 2003; SAARELA et al., 1999). A capacidade de metabolizar a diadenosina tetrafosfato poderia ser essencial para a bactéria invadir a célula alvo, sendo que, altas concentrações desta alarmona são encontradas em bactérias mutantes defectivas em gene apaH. A deleção do gene apaH em E. coli leva a um aumento de 10 a 100 vezes no nível intracelular de diadenosina tetrafosfato (LÉVÊQUE et al., 1990), enquanto em Salmonella typhyimurium, é observado um aumento de 3,5 vezes no nível intracelular de diadenosina tetrafosfato após a deleção deste gene, o suficiente para provocar um fenótipo não invasivo (ISMAIL et al., 2003). $\mathrm{O}$ gene apaH também foi associado com invasão celular por A. actinomycetemcomitans (SAARELA et al., 1998). No presente estudo, o gene apaH foi regulado positivamente após adesão a células epiteliais somente para a amostra ATCC29523 em 24 horas (figura 5B), diferindo das amostras SUNY 465 e JP2, em que foi regulado negativamente após adesão a células epiteliais.

Assim, os dados de regulação positiva da transcrição de genes codificando fatores de colonização como aae, flp e omp100 sugerem que, embora ATCC 29523 em cultura in vitro apresente menor eficiência de adesão às células epiteliais que as demais cepas testadas, esta deficiência seria ultrapassada após prolongada interação com células epiteliais, como ocorreria na cavidade oral. Por outro lado, alguns genes associados à virulência como cagE e omp29 não são transcritos a níveis detectáveis por ATCC 29523 em cultura in vitro, mas outros, como orf 859 o são após o contato com célula epitelial. Análises posteriores, usando como inóculo em células epiteliais, culturas das amostras bacterianas obtidas após interação prévia com células epiteliais poderiam confirmar estas observações iniciais, onde a transcrição de genes relacionados a adesinas como aae e flp são regulados positivamente em ATCC 29523.

Deste modo, o fato do nível de transcritos flp e aae em SUNY 465 após 2 horas de interação não ser maior que nas demais amostras, não justificaria a maior adesividade de SUNY 465. Por outro lado, após 2 horas de interação com células, a adesina Omp100 e PgA foram significativamente mais expressos em SUNY 465 comparada às demais. Os dados indicam que a interação entre células eucariontes e A. actinomycetemcomitans é complexa, e diferenças na 
eficiência de adesão das amostras não pode ser explicada por diferenças na transcrição dos genes que codificam flp e aae.

A observação de que a trasncrição do gene omp29 foi regulada positivamente somente nas cepas do sorotipo b, JP2 e SUNY 465, após contato com a célula epitelial, no intervalo de 2 horas, também é uma observação interessante. Na amostra ATCC 29523, sorotipo a, geralmente associado a pacientes com periodonto saudável, não foram detectados transcritos deste gene em nenhum dos intervalos de tempo analisados. A Omp 29 de A. actinomycetemcomitans pertence à família OmpA (WILSON, 1991). Esta família compreende proteínas de membrana externa conservadas em vários organismos patogênicos como OmpA de Salmonella enterocolitica Typhimurium (FREUDL e COLE, 1983); P5 de Haemophilus influenzae (MUNSON et al., 1993); MOMP de Haemophilus ducreyi (SPINOLA et al., 1993), OmpA de Escherichia coli (NIKAIDO et al., 1984), OmpA de Aeromonas salmonicida (COSTELO; VIPOND; MacINTYRE, 1996) e Omp de Pasteurella multocida (MARANDI et al., 1996). A OmpA de E. coli é a proteína mais abundante do envelope externo da parede de E.coli K-1 (WEISER e GOTSCHLICH, 1991), sendo esta proteína, multifuncional e associada à capacidade da bactéria invadir células endoteliais do cérebro (PRASADARAO; WASS; KIM, 1996), células glioma C6 (WU et al., 2009) e células dendríticas (MITTAL e PRASADARAO, 2008). Além disso, confere estabilidade à membrana celular (SONTEG et al., 1978), aumenta a resistência à atividade bactericida do soro e propicia maior virulência à bactéria em modelos animais experimentais (WEISER e GOTSCHLICH, 1991). Em E. coli patogênica para aves (APEC), a expressão de OMPA é regulada positivamente pelo contato com soro, indicando que membros desta família podem ser regulados pelo ambiente in vivo (TYLER et al., 2008). As proteínas desta família são altamente imunogênicas (SMITH et al., 2007), inclusive a de A.actinomycetemcomitans (KOMATSUZAWA et al., 1999), indicando a sua expressão in vivo. No presente estudo houve regulação positiva da transcrição de omp29 após $24 \mathrm{~h}$ em meio contendo fatores de crescimento (insulina, fator de crescimento epidermal e fator de crescimento de fibroblastos), sendo inclusive o nível de transcritos mais alto do que após o mesmo período de contato com células epiteliais (Figura 14), indicando que estas condições associadas ao maior tempo de incubação no meio, como as relacionadas a quorum sensing e à presença de fatores de crescimento, seriam as responsáveis pela regulação positiva de omp29. É interessante notar também que na cepa JP2 após 24 h em contato com a célula epitelial houve regulação positiva da 
transcrição de flp-1 e omp29 em A. actinomycetemcomitans (Figuras 3 e 14). Em E. coli, OmpA , além de promover a ligação direta a células BMECs, exerce sua influência na ligação bacteriana pela modulação da expressão da fímbria tipo 1 (SMITH et al., 2007). Estudos anteriores, realizados neste laboratório, mostraram que a resposta contra Omp29 não ocorre em todos os pacientes colonizados por A. actinomycetemcomitans (ANDO et al., 2010; BRUNHEIRA 2007). Associadas aos dados aqui obtidos, estas observações sugerem que a expressão de Omp29 seja diferente entre amostras de A. actinomycetemcomitans.

Os produtos dos genes orf 859 e vapA não apresentam ainda um papel definido na virulência. $\mathrm{O}$ que se sabe a respeito do gene orf 859 refere-se à sua possivel relação com a sobrevivência intracelular de A. actinomycetemcomitans após invasão em células epiteliais (CAO et al. 2004). Em estudos utilizando a técnica antígeno induzido in vivo (IVIAT), que permite a rápida identificação de genes de A. actinomycetemcomitans expressos especificamente durante a infecção, permitiram a identificação de 116 antígenos induzidos in vivo (SONG et al, 2002). Em estudo posterior, os primeiros nove genes induzidos $(l k t B, v a p A$, orf 327, orf 554, orf 859, orf 871, orf 1184, orf 1402 e orf 1623), identificados por IVIAT, foram alvos de estudos com PCR em tempo real e foi demonstrado aumento de trasncrição dos genes orf 859 e vapA da cepa VT1169 de A. actinomycetemcomitans após contato com célula epitelial (CAO et al., 2004). Em nosso estudo, o gene orf859 não foi transcrito pela amostra ATCC 29523 (sorotipo a) em nenhuma das condições (controle e adesão) no intervalo de 2 horas de infecção, mas em 24 horas de infecção foi regulado positivamente após adesão à célula epitelial superando o nível de transcrição das demais amostras que já apresentavam em baixos níveis de trasncritos em 2 horas (Figuras 11A e B).

$\mathrm{O}$ gene vapA está relacionado à virulência por sua homologia à região vap de Dichelobacter nodosus, que é encontrada em 98\% das cepas virulentas e ausente em $70 \%$ das cepas avirulentas (BLOOMFIELD et al., 1997). A amostra SUNY 465, apresentou regulação positiva da trasncrição de vapA após adesão, sendo a amostra que apresentou o maior nível de transcritos vapA em 2 horas, embora o nível de transcrição tenha sido superado pela amostra ATCC29523 após 24 horas de adesão (Figuras 12A e B).

O produto do gene cagE de A. actinomycetemcomitans está envolvido na apoptose da célula hospedeira (TENG e HU, 2005). Mutantes de Helicobacter pylori deficientes no gene homólogo cagE induziram menor grau de lesões gástricas que a cepa selvagem, sugerindo seu 
possível envolvimento na patogênese (OGURA et al., 2000). O gene cagE foi transcrito apenas por JP2 no intervalo de 2 horas, e após 24 horas foi observada transcrição também na amostra SUNY465, em baixos níveis, não apresentando diferenças na regulação após adesão a célula epitelial (Figuras 13 A e B), enquanto a amostra ATCC29523 não apresentou transcrição deste gene em nenhuma das condições analisadas, independente do intervalo de tempo. Este dado sugere uma maior virulência de amostras do sorotipo b, como SUNY 465 e JP2, do que do sorotipo a (ATCC 29523).

O gene $p g A$, que codifica o polissacarídeo extracelular de A. actinomycetemcomitans foi o único regulado positivamente após a adesão para todas as amostras em todos os intervalos de tempo. O polissacarídeo PGA é o principal componente da matriz do biofilme de $A$. actinomycetemcomitans, que confere também resistência a antibióticos, representando um importante fator de virulência bacteriana (KAPLAN et al., 2004).

Assim, os dados da análise da trasncrição gênica bacteriana após interação com célula epitelial indicam que a A. actinomycetemcomitans apresenta mecanismos de reconhecimento do ambiente, que sinaliza para a expressão de genes necessários à sua sobrevivência no ambiente. Alguns genes foram regulados positivamente pela presença em célula epitelial em todas as amostras, como $p g A$, e em outros a transcrição não foi alterada pelas condições estudadas, como $\operatorname{cagE}$. No entanto, foi observada grande distinção no perfil de trasncritos entre a amostra do sorotipo a (ATCC 29523) e as amostras do sorotipo b (JP2 e SUNY 467). A transcrição de fatores relacionados à colonização como a transcrição de genes codificando as adesinas flp e aae foram maiores na amostra do sorotipo a (ATCC29523) dentro das condições analisadas, do que nas amostras do sorotipo b. Por outro lado, genes associados a virulência como cagE, omp29, ltx foram transcritos exlusivamente ou em maior nível pelas amostras do sorotipo b, justificando a maior associação deste sorotipo com a periodontite agressiva. Assim, os dados sugerem também que a regulação de genes de virulência em A. actinomycetemcomitans pode ser considerada cepaespecífica.

As células do hospedeiro também reconhecem a presença dos microrganismos e se adaptam às novas condições, na tentativa de controlar a infecção. Além disso, bactérias patogênicas manipulam a resposta do hospedeiro visando aumentar a sua sobrevivência pela ativação ou inibição das vias de sinalização da célula eucarionte. 
O reconhecimento dos patógenos é mediado por receptores presentes na membrana das células epiteliais, referidos como receptores padrões de reconhecimento (PRR) ou receptores Toll-Like (TLR). Onze membros da família de receptores Toll-like (TLR) já foram identificados. Estudos in vitro têm mostrado expressão de TLR1, TRL2 e TRL6 em células epiteliais gengivais primárias, embora apenas TRL 2 e TRL 4 tenham sido relatados em tecido gengival de pacientes com periodontite (ASAI et al., 2001). A ativação dos TLRs através da interação receptor-ligante é um evento crítico no desencadeamento da resposta imune, que resulta na tentativa de eliminação do patógeno através da liberação de uma série de citocinas, peptídeos antimicrobianos e quimiocinas. Estes receptores reconhecem regiões altamente conservadas, comuns em amplo grupo de microrganismos que contém lipopolissacarídeo (LPS) e peptidoglicano (ESKAN et al., 2008b).

Embora os TLRs reconheçam componentes estruturais conservados entre as diferentes classes de microrganismos, existem diferenças entre organismos na ligação com estes receptores, resultando em diferenças na resposta inflamatória provocada por diferentes patógenos. Por exemplo, o lipopolissacarídeo (LPS) de A. actinomycetemcomitans pode se ligar tanto aos receptores TLR4 como TLR2, enquanto o LPS de $P$. gingivalis parece estimular exclusivamente TLR2 (KIKKERT et al., 2007).

Existem amplas evidências demonstrando diferenças na transcrição de genes codificando citocinas após a ativação de TLR2 ou TLR4 (PULENDRAN et al., 2001; RE e STROMINGER, 2001). Apesar de o LPS de A. actinomycetemcomitans induzir a produção de citocinas proinflamatórias por células do sangue periférico humano, assim como o LPS de E. coli (SCHYTTE-BLIX et al., 1999), LPS de A. actinomycetemcomitans induz maior produção de IL12 e da molécula coestimulatória CD86 por células dendríticas do que o LPS de E. coli (KIKUCHI et al., 2004). Além disso, foi demonstrado que LPS de A. actinomycetemcomitans pode induzir reabsorção óssea in vitro (ISHIHARA et al., 1991) e in vivo (NISHIDA et al., 2001), e pode também afetar a produção de colágeno (TAKAHASHI et al., 2008).

A infecção por A. actinomycetemcomitans induz forte resposta inflamatória. Na doença periodontal, ocorre colonização bacteriana das superfícies do dente e do epitélio interno do sulco gengival (SLOTS e GENCO, 1984; ZAMBON et al., 1985). Esta colonização induz à resposta do hospedeiro que representa um papel essencial no desenvolvimento da doença. O mecanismo intermediário entre a estimulação bacteriana aliada aos fatores de virulência e a resposta do 
hospedeiro com destruição do tecido periodontal é a secreção de citocinas, que culmina nos eventos inflamatórios. A produção de citocinas não é exclusiva de leucócitos, pois outras células também atuam na sua liberação, como queratinócitos, células mesenquimais, células dendríticas, células endoteliais e células epiteliais da mucosa (GRAVES, 2008).

Recentemente, estudos vêm apontando a participação efetiva das células epiteliais estimuladas por Porphyromonas gingivalis e por A. actinomycetemcomitans na secreção de citocinas (DAYAN et al., 2004; ESKAN et al., 2008a; MILWARD et al., 2007; SHIMADA et al., 2008).

Embora o epitélio do sulco gengival, assim como do trato gastrointestinal, possa apresentar uma resposta imune caracterizada por um estado de hipo-resposta às bactérias residentes (SHALE e GOSH, 2009), os dados aqui apresentados suportam a hipótese de que as células epiteliais gengivais mantêm a capacidade de montar uma resposta contra os patógenos, como A. actinomycetemcomitans, quebrando assim o equilíbrio observado no estado da saúde periodontal, induzindo a produção de TNFa, IL-1 e GM-CSF, entre outros. Ao contrário dos dados aqui apresentados, foi demonstrado que células epiteliais orais primárias de humanos e células epiteliais de linhagem HSC-2 e HO-1-u-1 na presença de componentes bacterianos ou componentes sintéticos dos PAMPS (padrões moleculares associados ao reconhecimento de patógenos), não secretam citocinas pro-inflamatórias, como IL-8 e GM-CSF, apesar de secretarem beta -defensinas (UEHARA et al., 2007). Assim, é possível que somente a presença de certos componentes bacterianos não seria suficiente para estimular a secreção de citocinas pelas células epiteliais, sendo necessária a viabilidade bacteriana, e possivelmente a sua internalização, e que outros fatores de virulência sejam expressos. Os dados apresentados neste estudo, onde a expressão de certos fatores de virulência, como omp29, cagE, pgA, principalmente após $24 \mathrm{~h}$ de interação com as células, associados à demonstração da invasividade da cepa empregada e à produção de citocinas pelas células epiteliais, suportam esta hipótese.

Dados de outros estudos também suportam esta hipótese. A invasão de células epiteliais por E. coli associada a OmpA (homóloga à Omp29 de A. actinomycetemcomitans) induz a expressão de citocinas diferindo do que ocorre com cepas não invasivas (PRASADARAO; WASS; KIM, 1996). 
De fato, foi postulado que a baixa resposta aos PAMPS pelas células epiteliais pode ser relacionada à incapacidade destas células em distinguir entre patógenos e membros da microbiota comensal, e outros fatores como invasão celular ou sinais de patogenicidade seriam requeridos para induzir a resposta inflamatória, cujo excesso leva também a destruição tecidual (UEHARA et al., 2007).

As moléculas citosólicas de reconhecimento de patógeno, como os receptores com domínio 1 de ligação de nucleotídeos e oligomerização (NOD1), reconhecem motivos específicos conservados no peptidoglicano da parede celular de bactérias Gram negativas (GIRARDIN et al., 2003). O peptidoglicano de H. pylori é reconhecido pela célula hospedeira via T4SS por NOD1 citosólico, que leva à ativação completa das vias de sinalização (VIALA et al., 2004). De fato, NOD1 é necessário para a completa ativação de MAPK em estágios precoces da infecção, sendo necessário também para a ativação de NF-kB e AP-1, assim como para a liberação de citocinas pró-inflamatórias em resposta à infecção. Então, a ativação MAPK-NOD1 dependente pode representar uma via de sinalização adicional em que o patógeno controla a transcrição de genes alvos durante a infecção (ALLISON et al., 2009). Foi também relatado que NOD1 pode ser requerido para a ativação da via NF-kB em resposta a patógenos bacterianos, como Shiguella flexineri e Listeria monocytogenes, capazes de invadir células não fagocíticas (GIRARDIN et al., 2001; OPITZ et al., 2006). Assim, é possível que a capacidade de internalização de A. actinomycetemcomitans em células epiteliais, demonstrada neste e em outros estudos (MEYER et al., 1996), permita que não somente os receptores de superfície, mas também os receptores intracelulares, como NOD, sejam ativados na infecção.

$\mathrm{Na}$ análise da expressão gênica da via de transdução de sinais em célula epitelial gengival, 15 genes foram regulados positivamente após 24 horas de infecção com $A$. actinomycetemcomitans. O gene codificando CSF2, também denominado fator de estimulação de colônias de granulócitos e macrófagos (GM-CSF), foi o gene mais estimulado (170 vezes) neste estudo. GM-CSF promove diferenciação de células da medula óssea em células precursoras de granulócitos, monócitos, macrófagos e células dendríticas (SEYDEL et al., 2008).

GM-CSF pode também ser relacionado com a osteoclastogênese humana, resultante de um efeito bifásico, em que a exposição ao GM-CSF em curto período estimula a diferenciação das células precursoras em osteoclastos e por tempo prolongado, estimula a diferenciação em células dendríticas, ou seja, o GM-CSF pode ter efeito estimulatório ou inibitório da 
osteoclastogênese, embora o efeito inibitório da osteoclastogênese ainda seja alvo de discussão (HODGE et al., 2004a; HODGE; KIRKLAND; NICHOLSON, 2004b). A sua associação com a osteoclastogênese pode ser suportada também pela observação de que GM-CSF é encontrado em altos níveis no líquido sinovial de pacientes com artrite reumatóide (NOMURA et al., 2008), uma doença inflamatória caracterizada pelo processo destrutivo das articulações decorrentes da erosão óssea, área onde se concentram os osteoclastos (SCHETT, 2009). Se a hipótese de indução da reabsorção óssea por GM-CSF for confirmada, então a indução deste fator pela bactéria induziria uma osteoclastogênese "inflamatória" adicional à que ocorre na osteoclastogênese induzida por M-CSF (NOMURA et al., 2008). Assim, a regulação positiva de GM-CSF em células infectadas por A. actinomycetemcomitans, confirmada pelos dados obtidos da análise funcional em células epiteliais e apoiada na observação de altos títulos de GM-CSF nos tecidos gengivais de pacientes com periodontite agressiva, sugere que as células epiteliais também estão envolvidas na sinalização induzindo osteoclastogênese na doença periodontal.

O tecido ósseo em condições fisiológicas normais apresenta-se em equilíbrio entre formação óssea por osteoblastos e reabsorção óssea por osteoclastos. Este equilíbrio promove a homeostase do tecido ósseo, incluindo a manutenção da integridade estrutural e o metabolismo de cálcio (COCHRAN, 2008). Ao contrário do que ocorre nas condições normais, em condições patológicas inflamatórias, como periodontite, osteoporose e outras, ocorre desequílibrio favorecendo a osteoclastogênese, e consequentemente maior reabsorção óssea. Além do GMCSF, outras citocinas, cuja transcrição foi regulada positivamente nas células infectadas, como IL-1 e TNF- $\alpha$, participam do processo de reabsorção óssea, pela indução da expressão de RANKL (FUKUSHIMA et al., 2005).

RANKL, é um membro da família do TNF, em que a ligação ao seu receptor RANK (fator ativador nuclear kappa B) resulta no recrutamento de proteínas da família TRAF, como TRAF6, que assim, ativam a via NFkB e JNK (TAKANAYAGI et al., 2002). Na periodontite, ocorre reabsorção óssea que é localmente regulada por células do sistema imune e células do tecido periodontal que expressam o ligante RANK. RANKL, secretado ou associado à superfície celular de osteoblastos, fibroblastos periodontais, e principalmente de linfócitos T e B (KAWAI et al., 2006), induz à diferenciação de osteoclastos pelos precursores hematopoiéticos e é essencial para a formação, função e sobrevivência dos osteoclastos, estando envolvido não somente na osteoclastogênese fisiológica, mas também patológica. Foi demonstrado que LPS 
(TIRANATHANAGUL et al., 2004) e CDT (BELIBASAKIS et al., 2005a ; BELIBASAKIS et al., 2005b) de A. actinomycetemcomitans induzem a expressão de RANKL por células do ligamento periodontal e este aumento na expressão de RANKL por vários tipos celulares ativa RANK em células pré-osteoclásticas, induzindo a osteoclastogênese e subseqüente reabsorção óssea (HAN et al., 2009).

No presente estudo, foi demonstrada a regulação positiva da expressão de interleucina- $1 \alpha$ (IL-1 $\alpha$ ) pelas células infectadas por A. actinomycetemcomitans. Estudo recente mostrou que células epiteliais gengivais são capazes de produzir e secretar IL-1 $\beta$ após estímulo com $P$. gingivalis, mediado por inflamassoma Nalp3 (YILMAZ et al., 2010). A família da IL-1 é o principal mediador inflamatório e apresenta-se em duas principais isoformas: IL-1 $\alpha$ e IL-1 $\beta$. No arranjo de genes analisados não havia iniciadores para IL-1 $\beta$, apenas para IL-1 $\alpha$. Cada isoforma é produto de dois genes separados, mas relacionados estruturalmente a nível tridimensional. A maior parte de IL-1 $\alpha$ produzida permanece intracelularmente na forma precursora e acredita-se funcionar como mensageiro autócrino. No entanto, há evidências que uma parte destes precursores sejam transportados para a superfície celular e associados com a membrana celular. Têm sido postulado que IL-1 $\alpha$ também possa atuar como mensageiro parácrino nas células adjacentes (DINARELLO et al., 1993). Ao contrário de IL-1 $\beta$, que é liberada da célula para o espaço extracelular atuando como mediador sistêmico, IL-1 $\alpha$ atua como mediador da inflamação local (MOLTO e OLIVE, 2010). A ação biológica da IL-1 foi associada à indução de febre, anorexia, hipotensão, leucopenia e trombocitopenia em estudos com injeções sistêmicas de IL-1 recombinante. No sistema hematopoiético, IL-1 aumenta a produção de fatores estimuladores de colônias e fatores de células tronco, agindo sinergisticamente com estes fatores para aumentar a produção de granulócitos e plaquetas. Nas articulações, IL-1 estimula os condrócitos a liberarem colagenase e outras enzimas proteolíticas envolvidas na degradação da cartilagem (MOLTO e OLIVE, 2010).

IL-1 também estimula a expressão de RANKL nas células do ligamento periodontal e inibe a expressão do receptor antagonista osteoprotegerina (OPG) (FUKUSHIMA et al., 2005). Além disso, IL-1 também estimula a diferenciação das células progenitoras de osteoclastos e contribui na ativação e maturação de osteoclastos levando à reabsorção óssea (MOLTO e OLIVE, 2010). Estudos realizados com camundongos transgênicos expressando altos níveis de IL-1 $\alpha$ no epitélio oral mostraram o desenvolvimento de uma síndrome apresentando 
características da periodontite severa, como formação de bolsa periodontal e reabsorção óssea (DAYAN et al., 2004). Assim, a regulação positiva da expressão de IL-1 (4,0 vezes) pelas células epiteliais após a infecção por A. actinomycetemcomitans, demonstrada no presente estudo, poderia contribuir ainda mais com a destruição dos tecidos de suporte do dente, incluindo a destruição do ligamento periodontal e osso alveolar, culminado na perda dentária, pois IL-1 exibe intensa atividade colagenolítica e atividade de rebsorção óssea tanto in vitro (GOWEN et al., 1983), como in vivo (BOYCE; YATES; MUNDY, 1989).

O segundo gene mais estimulado neste estudo foi $\operatorname{tnf}(28,93$ vezes), que codifica TNF- $\alpha$, um potente mediador inflamatório. Entre outras funções, TNF- $\alpha$ apresenta capacidade de ativar a via NFkB e as três cascatas das vias MAP quinases (MECHTCHERIAKOVA et al., 2001). A ativação da via NFkB, ocorre devido à capacidade de TNF- $\alpha$, além de IL-1, fosforilar a proteína inibitória IkB, permitindo a translocação do NFkB ao núcleo (COCHRAN, 2008; YAMAMOTO et al., 2008), e assim, a indução da transcrição de genes como CCL20, ICAM1, IL1- $\alpha$ e BIRC3; regulados positivamente neste estudo pelas células epiteliais gengivais após infecção com $A$. actinomycetemcomitans. Já havia sido demonstrado que Porphyromonas gingivalis apresenta a capacidade de induzir a produção de TNF- $\alpha$ em cultura de células epiteliais tumorais $\mathrm{KB}$, cultura de fibroblastos e cultura primária de células epiteliais gengivais humanas (ROBERTS; MCCAFFERY; MICHALEK, 1997; SANDROS et al., 2000).

TNF- $\alpha$ também pode influenciar na osteoclastogênese, favorecendo a formação de precursores de osteoclastos através da indução da expressão de RANKL em células da medula óssea e osteoblastos de linhagem (WEI et al., 2005), além de interferir na maturação e diferenciação de osteoblastos com redução na expressão de fosfatase alcalina e osteocalcina (PANAGAKOS; HINOJOSA; KUMAR, 1994). Esta relação de TNF- $\alpha$ com a osteoclastogênese foi demonstrada também em estudo com modelo de primatas não humanos, em que a inibição de TNF- $\alpha$ e IL-1 levou à redução da progressão de perda óssea alveolar e perda de inserção (ASSUMA et al., 1998; DELIMA et al., 2001). Em nosso estudo, a análise funcional de TNF- $\alpha$ foi realizada por ELISA no sobrenadante das células epiteliais gengivais infectadas por $A$. actinomycetemcomitans JP2, confirmando-se a sua expressão nas células infectadas. Amostras de tecido gengival de indivíduos periodontalmente saudáveis e de pacientes apresentando periodontite agressiva e crônica, também analisados por ELISA, mostrararam altos níveis na concentração de TNF- $\alpha$, com diferenças estatisticamente significantes entre as amostras de 
pacientes com periodontite em relação aos indivíduos saudáveis, mas não entre as doenças agressiva e crônica.

No presente estudo, as células gengivais infectadas por A. actinomycetemcomitans JP2, também apresentaram regulação positiva na expressão gênica de ICAM-1 de 7,67 vezes, quando comparadas às células controle sem infecção. A molécula de adesão intercelular, ICAM-1, é um mediador inflamatório cuja expressão é regulada positivamente por TNF- $\alpha$ (TANCHAROEN et al., 2008). O aumento da expressão de ICAM-1 por células epiteliais gengivais tem um importante papel no recrutamento e ativação de células como macrófagos e leucócitos no desenvolvimento da doença periodontal (SUGIYAMA et al., 2002) e estudos mais recentes vem apontando o envolvimento de ICAM-1 na diferenciação de osteoclastos, promovendo alta afinidade de adesão entre os precursores de osteoclastos (FERNANDES et al., 2008; BLOEMEN et al., 2009). Recentemente foi relatada a regulação positiva de ICAM-1 em células gengivais infectadas por A. actinomycetemcomitans (SHIMADA et al., em 2009) e anteriormente por Prevotella intermedia (SUGIYAMA et al., 2002). A produção de ICAM-1 também é estimulada em células epiteliais respiratórias após interação com Haemophilus influenzae mediada pela fímbria p5 (AVADHANULA et al., 2006) que é homóloga a OMP29 de A.actinomycetemcomitans (MUNSON et al., 1993).

A análise funcional da produção de ICAM-1 também foi confirmada por ELISA, analisando-se o sobrenadante das células epiteliais gengivais infectadas por $A$. actinomycetemcomitans JP2. Amostras de tecido gengival de indivíduos periodontalmente saudáveis e pacientes apresentando periodontite agressiva e crônica também foram analisadas por ELISA, e os resultados mostrararam diferenças estatisticamente significantes na concentração de ICAM-1, com maior concentração deste mediador em amostras de pacientes com periodontite do que nas amostras de indivíduos saudáveis, mas não entre as doenças agressiva e crônica.

erg 1 ("early growth response 1"), o terceiro gene mais estimulado nas células epiteliais infectadas (14,08 vezes), codifica ERG-1, um fator de transcrição que regula a expressão de TNF $\alpha$, da proteína inflamatória de macrofágos (MIP2), da proteína quimioatraente de monócitos (MCP1 ou CCL2), e de ICAM (molécula de adesão intercelular), ou seja, regula a transcrição de genes envolvidos na inflamação, coagulação, imunidade adaptativa e inata. Devido a isso, EGR1 tem sido considerado importante regulador, rapidamente expresso em resposta a uma variedade 
de estímulos incluindo fatores de crescimento, LPS, hipoxia, e componentes oxigênio reativos (PRITCHARD et al., 2007). Em ação conjunta com c-FOS, cujo gene também foi estimulado neste estudo após a infecção das células epiteliais por A. actinomycetemcomitans (4,47 vezes), a regulação positiva de erg 1 atuaria possivelmente, na regulação transcricional da expressão de colagenase, evidenciando um importante papel na destruição do tecido periodontal e gengival (TRABANDT et al., 1992). Além disso, a regulação positiva de c-FOS, um fator de transcrição essencial para a diferenciação de osteoclastos (TAKANAYAGI et al., 2002), indica a existência de mecanismo adicional de indução de reabsorção óssea logo após o contato da bactéria com as células epiteliais.

Vale ressaltar que a expressão das quimiocinas também foi estimulada neste estudo, como CCL2 (MCP-1) (12,18 vezes) e CCL20 (6,49 vezes). O papel clássico das quimiocinas envolve a migração de leucócitos para o sítio infectado, sendo que estudos recentes vêm apontando o possível envolvimento de CCL2 também com a migração de células préosteoclásticas (LEE et al., 2000). Já foi relatado que a estimulação na expressão de quimiocinas na periodontite agressiva pode estar relacionada ao aumento da severidade da doença (GARLET et al., 2003).

Neste estudo, a via pró-apoptótica p53, representada pela regulação positiva de genes $c d k n 1 a$ (4,88 vezes) e gadd45a (8,0 vezes), foi ativada nas células gengivais pela infecção por $A$. actinomycetemcomitans. A via p53 também pode ser ativada quando ocorre dano no DNA ou em condições de hipoxia (redução no suprimento de oxigênio) (CORN e EL-DEIRY, 2007). A toxina CDT de A. actinomycetemcomitans provoca dano ao DNA e conseqüente ativação da via p53 (SATO et al., 2002; HANDFIELD et al., 2005; AMARAL et al., 2010), levando à parada do ciclo celular na fase G2 em diferentes células alvo humanas (SATO et al., 2002). A parada do ciclo celular da fase G2/M é parcialmente devido à ativação da via p53 através da regulação positiva de p21 (produto do gene CDKN1A) (GORJALA e GARY, 2010) e GADD45A (NAIDU et al., 2007). p53 regula a transição G2/M via modulação da quinase ciclina dependente (cdc2), que é essencial para as células completarem a mitose. A ligação à ciclina $\mathrm{C}$ e fosforilação da tirosina 15 e treonina 14 da cdc2 são realizadas pelas quinases Wee1 e Myt 1, respectivamente. No início da mitose, ambos os resíduos são defosforilados pela fosfatase cdc25. Diferentes alvos transcricionais da via p53 podem inibir cdc2. A p21 pode inibir cdc2, através da ativação da proteína 14-3-3s, que ancora cdc2 no citoplasma, impedindo assim, a mitose. Além disso, a 
ativação de GADD45A também pode inibir cdc2 através da dissociação da ciclina B1. Desta maneira, a repressão da ciclina B1 e cdc2 reforça a parada do ciclo celular na fase G2/M (NAIDU et al., 2007).

Em relação a ativação da via PI3K, esta ocorreu através da regulação positiva de jun em células epiteliais após infecção por A. actinomycetemcomitans. A via de sinalização da quinase-3 fosfatidilinositol (PI3K) depende do balanço molecular entre a subunidade catalítica e regulatória (UEKI et al., 2002). A resposta celular após ativação desta via pode ocorrer de maneira distinta em consequência da ativação de diferentes genes alvos. Na infecção promovida por uma série de patógenos que invadem células não fagocíticas pelo mecanismo "zíper", receptores de superfície da membrana celular são ativados independentemente do sistema de secreção tipo III (COSSART e SANSONETTI, 2004; PIZARRO-CERDA e COSSART, 2006). Salmonella typhimurium utiliza a PI3K como quinase alvo para possibilitar sua entrada em fibroblastos, mas não em células epiteliais (AIASTUI, 2010). A ativação da quinase P13 pode estar relacionada à inibição da apoptose em células infectadas com o vírus da influenza (LU et al., 2010), como também em $P$. gingivalis, cuja infecção resulta em um cenário antiapoptótico. Ao contrário de A. actinomycetemcomitans que não usa esta mesma estratégia para manter-se no ambiente intracelular, pois esta escapa rapidamente da célula hospedeira, dirigindo-se para outras células vizinhas (MEYER e FIVES-TAYLOR, 1996).

A via das MAP quinases também está envolvida com a entrada de patógenos, pois MEK1 apresenta um papel relevante no modo de entrada SPI-independente em certos fibroblastos (AIASTUI et al., 2010). O módulo MEK/ERK das MAP quinases parece agir como ponto de convergência da cascata de sinalização iniciada por TNF- $\alpha$ e VEGF (gene vegf regulado positivamente neste estudo em 4,59 vezes). O VEGF ativa principalmente as vias ERK1/2 e p38 quinases, mas não JNK. Enquanto o TNF- $\alpha$ ativa todas as três vias das MAP quinases, além da ativação da via NFkB (MECHTCHERIAKOVA et al., 2001).

Assim, os dados apresentados neste estudo, demonstraram que a interação entre $A$. actinomycetemcomitans e as células epiteliais gengivais provoca alterações tanto na expressão gênica dos fatores de virulência da bactéria como na ativação das vias de transdução de sinais da célula epitelial. A resposta exacerbada do hospedeiro com a produção elevada de citocinas proinflamatórias como GM-CSF/CSF2, TNF- $\alpha$, e moléculas de adesão ICAM-1, demonstrada neste estudo, tanto in vitro (sobrenadante das células epiteliais infectadas) como in vivo (amostras de 
tecido gengival), deve desempenhar um papel importante nos eventos que levam a destruição observada nos quadros de periodontite agressiva. 


\section{CONCLUSÕES}

Este estudo demonstrou através da análise da expressão gênica, duas vertentes existentes no processo de infecção, de um lado, a bactéria e do outro, a célula epitelial:

1. A. actinomycetemcomitans altera o perfil de transcrição de genes após a interação com células epiteliais gengivais. A regulação da transcrição de certos genes de virulência após contato com a célula epitelial é cepa específica. Além disso, a regulação da transcrição também é dependente do tempo de contato com a célula epitelial. A maior virulência das amostras de A.actinomycetemcomitans pertencentes ao sorotipo $\mathbf{b}$, em relação à amostra sorotipo a pode ser justificada pela regulação positiva de genes associados a maior virulência como ltx, que codifica a leucotoxina e omp29. Além disso, a interação com células epiteliais induziu a transcrição de genes associados à colonização, como $f l p$ e aae, particularmente nas amostras sorotipo a. Por outro lado, diferenças entre as amostras sorotipo b, foram detectadas. Embora a cepa JP2 tenha apresentado maior transcrição de ltx após cultura in vitro, a regulação positiva de ltx após contato com célula epitelial por 24 horas na amostra SUNY465, levou a produção de transcritos ltx em níveis similares ao observado na amostra JP2, justificando a participação das linhagens sorotipo b não JP2 na periodontite agressiva;

2. A transcrição gênica de células epiteliais gengivais sofre alterações após a infecção por A.actinomycetemcomitans, sugerindo que o cenário da periodontite agressiva, caracterizado por infiltrado macrofágico e destruição óssea, inicia-se precocemente durante a infecção, após a interação da bactéria com o epitélio. 


\section{REFERÊNCIAS}

ABDUL-SATER, A. A.; SAID-SADIER, N.; OJCIUS, D. M.; YILMAZ, Ö.; KELLY, K. A. Inflammasomes bridge signaling between pathogen identification and the immune response. Drugs Today, v. 45, p. 105-112, 2009.

AIASTUI, A.; PUCCIARELLI, M. G.; GARCIA-DEL-PORTILLO, F. Salmonella enterica serovar typhimurium invades fibroblasts by multiple routes differing from the entry into epithelial cells. Infect. Immun., v. 78, p. 2700-2723, 2010.

AKIFUSA, S.; HEYWOOD, W.; NAIR, S.P; STENBECK, G.; HENDEERSON, B. Mechanism of internalization of the cytolethal distending toxin of Actinobacillus actinomycetemcomitans. Microbiol., v. 151, p. 1395-1402, 2005.

AMARAL, J. D.; XAVIER, J. M.; STEER, C. J.; RODFRIGUES, C. M. Targeting the p53 pathway apoptosis. Curr. Pharm. Des. 2010. (in press)

AMBILI, R.; SANTHI, W. S; JANAM, P.; NANDAKUMAR, K.; PILLAI, M. R. Expression of activated transcription factor nuclear factor-kappaB in periodontally diseases tissues. J. Periodontol., v. 76, p. 1148-1153, 2005.

ANDO, E. S.; DE-GENARO, L. A.; FAVERI, M.; FERES, M.; DiRIENZO, J. M.; MAYER, M. P. A. Immune response to cytolethal distending toxin of Aggregatibacter actinomycetemcomitans in periodontitis patients. J. Periodontol. Res., 2010 (in press), doi:10.1111/j.1600-0765.2009.01260.x

ASAI, Y.; OHYAMA, Y.; GEN, K.; OGAWA, T. Bacterial fimbriae and their peptides activate human gingival epithelial cells through toll-like receptor 2. Infect. Immun., v. 69, p. 7387-7395, 2001

ASAKAWA, R.; KAWAI, T.; KOMATSUZAWA, H.; YAMADA, S.; GONÇALVES, R. B.; IZUMI, S.; SUZUKI, N.; UCHIDA, Y.; OUHARA, K.; SHIBA, H.; TAUBMAN, M. A.; KURIHARA, H.; SUGAI, M. Outer membrane protein 100, a versatile virulence factor of Actinobacillus actinomycetemcomitans. Mol. Microbiol., v. 50, p. 1125-1139, 2003.

ASSUMA, R.; OATES, T.; COCHRAN, D.; AMAR, S.; GRAVES, D. T. IL-1 and TNF antagonists inhibit the inflammatory response and bone loss in experimental periodontitis. J. Immunol., v.160, p. 403-409, 1998.

BELIBASAKIS, G. N.; JOHANSSON, A.; WANG, Y.; CHEN, C.; LAGERGARD, T.; KALFAS, S.; LERNER, U. H. Cytokines responses of human gingival fibroblasts to 
Actinobacillus actinomycetemcomitans cytolethal distending toxin. Cytokine., v. 30, p. 56-63, 2005a.

BELIBASAKIS, G. N.; JOHANSSON, A.; WANG, Y.; CHEN, C.; KALFAS, S.; LERNER, U. $\mathrm{H}$. The cytolethal distending toxin induces receptor activator of NF-kB ligand expression in human gingival fibroblasts and periodontal ligament cells. Infect. Immun., v. 73, p. 342-351, $2005 b$.

BESSMAN, M. J.; WALSH, J. D.; DUNN, C. A.; SWAMINATHAN, J.; WELDON, J. E.; SHEN, J. The gene ygdP, associated with the invasiveness of Escherichia coli K1, designates a Nudix hydrolase, Orf176, active on adenosine (5')-pentaphospho-(5')-adenosine (Ap5A). J. Biol. Chem., v. 276, p. 37834-37838, 2001.

BLOEMEN, V.; VRIES, T. J.; SHOENMAKER, T.; EVERTS, V. Intercellular adhesion molecule-1 clusters during osteoclastogenesis. Bioch. Biophys. Res. Commun., v. 385, p. 640645, 2009.

BLOMMFIELD, G. A.; WHITTLW, G.; McDONAGAH, M. B.; KATZ, M. E.; CHEETHAM, B. F. Analysis of sequences flanking the vap regions of Dichelobacter nodosus: evidence for multiple integration events, a killer system, and a new genetic element. Microbiology, v. 143, p. 553-562, 1997.

BOYCE, B. F.; YATES, A. J.; MUNDY, G. R. Bolus injections of recombinant human interleukin-1 cause transient hypocalcemia in normal mice. Endocrinology, v. 125, p. 27802783, 1989.

BROGAN, J. M.; LALLY, E. T.; POULSEN, K.; KILIAN, M.; DEMUTH, D. R. Regulation of Actinobacillus actinomycetemcomitans leucotoxin expression: analysis of the promoter regions of the leucotoxically and minimally leucotoxic strains. Infect. Immun., v. 62, p. 501-508, 1994.

BRUNHEIRA, A. T. P. Detecção de Aggregatibacter (Actinobacillus) actinomycetemcomitans no biofilme subgengival e títulos séricos IgG contra OMP100 e OMP29. 80 f. Tese (Mestrado) Instituto de Ciências Biomédicas, Universidade de São Paulo, São Paulo, 2007.

BUENO, L. C.; MAYER, M. P.; DiRIENZO, J. M. Relationship between conversion of localized juvenile periodontitis susceptile children form health to disease and Actinobacillus actinomycetemcomitans leucotoxin promoter structure. J. Periodontol., v. 69, p. 998-1007, 1998

CAO, S. L.; PROGULSE-FOX, A.; HILLMAN, J. D..; HANDFIELD, M. In vivo induced antigenic determinants of Actinobacillus actinomycetemcomitans. FEMS Microbiol. Lett., v. 237, p. 97-103, 2004.

CARVAlHO, F. M.; TINOCO, E. M. B.; DEELEY, K.; DUARTE, P. M.; FAVERI, M.; MARQUES, M. R.; MENDONÇA, A. C.; WANG, X.; CUENCO, K.; MENEZES, R.; 
GARLET, G. P.; VIEIRA, A. R. FAM5C contributes to Aggressive Periodontites. PloS ONE, v. 5, p. 1-10, 2010.

CHAMMAILARD, M.; GIRARDIN, S. E.; VIALA, J.; PHILPOTT, D. J. Nods, Nalps and Naip: intracellular regulators of bacterial-indiced inflammation. Cell. Microbiol., v. 5, p. 581-592, 2003.

CLARKE, M. C. H.; FIGG, N.; MAGUIRE, J. J.; DAVENPORT, A. P.; GODDARD, M. et al. Apoptosis of vascular smooth muscle cells features of plaque vulnerability in atherosclerosis. Nature Med., v. 12, p. 1075-1080, 2006.

COCHRAN, D. L. Inflammation and bone loss in periodontal disease. J. Periodontol., v. 79, p. 1569-1576, 2008.

CONELLY, J. J.; SHAH, S. H.; DOSS, J. F.; GADSON, S.; NELSON, S. et al. Genetic and functional association of FAM5C with myocardial infarction. BMC Med. Genet., v. 9, p. 33-47, 2008.

CORN, P. G; EL-DEIRY, W. S. Microarray analysis of p-53 dependent gene expression in response to hypoxia and DNA damage. Cancer Biol. Ther., v. 6, p. 1858-1866, 2007.

COSSART, P.; SANSONETTI, P. J. Bacterial invasion: the paradigms of enteroinvasive pathogens. Science, v. 304, p. 242-248, 2004.

COSTEA, D. E.; DIMBA, A. O. E.; LORO, L. L.; VINTERMYR, O. K.; JOHANNENSSEN, A. C. The phenotype of in vitro reconstituted normal human oral epithelium is essentially determined by culture medium. J. Oral. Pathol. Med., v. 34, p. 247-252, 2005.

COSTELO, G. M.; VIPOND, R.; MacINTYRE, S. Aeromonas salmonicida possess two genes encoding homologs outer membrane protein, OmpA. J. Bacteriol., v. 178, p. 1623-1630, 1996.

DAYAN, S.; STASHENKO, P.; NIEDERMAN, R.; KUPPER, T. S. Oral epithelial overexpression of IL-1 $\alpha$ causes periodontal disease. J. Dent. Res., v. 83, p. 786-790, 2004.

DARVEAU, R. P.; TANNER, A.; PAGE, R. C. The microbial challenge in periodontitis. Periodontol 2000, v. 14, p. 12-32, 1997

DELIMA, A. J.; OATES, T.; ASSUMA, R.; SCHARTZ, Z.; COCHRAN, D.; AMAR, S.; GRAVES, D. T. Soluble antagonists to interlukin-1 (IL-1) and tumor necrosis factor (TNF) inhibit loss of tissue attachment in experimental periodontits. J. Clin. Periodontol., v. 28, p. 233-240, 2001. 
DINARELlO, C. A.; WOLF, S. M. The role of interleukin-1 in disease. N. Engl. J. Med., v. 328, p. 106-113, 1993.

DOGAN, B.; SAARELA, M. H.; JOUSIMIES-SOMER, H.; ALALUUSUA, S.; ASIKAINEN, S. Actinobacillus actinomycetemcomitans serotype e - biotypes, genetic diversty and distribution in relation to periodontal status. Oral Microbiol. Immunol., v. 14, p. 98-103, 1999.

EICK, S.; REISSMANN, A.; RODEL, J.; SCHMIDT, K. H.; PFISTER, W. Porphyromonas gingivalis survives within KB cells and modulates inflammatory response. Oral Microbiol. Immunol., v. 21, p. 231-237, 2006

ESKAN, M. A., BENAKANAKERE, M. R.; ROSE, B. G.; ZHANG, P.; ZHAO J., STATHOPOULOU, P.; FUJIOKA, D. ; KINANE, D.F. Interleukin-1 $\beta$ modulates proinflamatory cytokine production in human epithelial cells. Infect. Immun., v. 76, p. 2080-2089, 2008a.

ESKAN, M. A.; ROSE, B. G.; BENAKANAKERE, M. R.; ZENG, Q.; FUJIOKA, D.; MARTIN, M. H.; LEE, M. J.; KINANE, D. F. TLR4 receptors cooperate to enhance inflammatory cytokine production in human gingival epithelial cells. Eur. J. Immunol., v. 38, p. 1138-1147, 2008b.

FABRIS, A. S.; DiRIENZO, J. M.; WIKSTRÖM, M.; MAYER, M. P. Detection of cytolethal distending toxin activity and cdt genes in Actinobacillus actinomycetemcomitans isolates from geographically diverse populations. Oral Microbiol. Immunol., v. 17, p. 231-238, 2002.

FAVERI, M.; FIGUEIREDO, L. C.; DUARTE, P. M.; MESTNIK, M. J.; MAYER, M. P. A.; FERES, M. Microbiological profile of untreated subjects with localized aggressive periodontits. J. Clin. Periodontol., v. 36, p. 739-749, 2009.

FERNANDES, J. C.; SHI, Q.; BENDERDOUR, M.; LAJEUNESSE, D.; LAVIGNE, P. An active role for soluble and membrane intercellular adhesion molecule -1 in osteoclast activity in vitro. J. Bone Miner. Metab., v. 26, p. 543-550, 2008.

FERNANDES, K.P.; MAYER, M.P.; ANDO, E.S.; ULBRICH, A.G.; AMARENTE-MENDES, J.G.; RUSSO, M. Inhibition of interferon-gamma- induced nitric oxide production in endotoxinactivated macrophages by cytolethal distending toxin. Oral Microbiol Immunol., v. 23, p. 360366, 2008.

FINE, D. H.; FURGANG, D.; KAPLAN, J.; CHARLESWORTH, J.; FIGURSKI, D. H. Tenacious adhesion of Actinobacillus actinomycetemcomitans strain CU1000 to salivary-coated hydroxyapatite. Arch. Oral Biol., v. 44, p. 1063-1076, 1999. 
FINE, D. H.; KAPLAN, J. B.; KACHLANY, S. C.; SCHEREINER, H. C. How we got attached to Actinobacillus actinomycetemcomitans: a model for infectious diseases. Periodontol 2000, v. 42, p. 114-157, 2006.

FINE, D. H.; MARKOWITZ, K., FURGANG, D.; FAIRLIE, K.; FERRANDIZ. J.; NASRI, C.; et al. Actinobacillus actinomycetemcomitans and its relationship to initiation of localized aggressive periodontitis: longitudinal cohort study of initially healthy adolescents. J. Clin. Microbiol., v. 45, p. 3859-3869, 2007.

FIVES-TAYLOR, P. M.; MEYER, D. H.; MINTZ, K. P.; BRISSETE, C. Virulence factors of Actinobacillus actinomycetemcomitans. Periodontol 2000, v. 20, p. 236-167.

FRANK, L.; WARNER, N.; VIANI, K.; NUÑEZ, G. Function of Nod-receptors in microbial recognition and host defense. Immunol. Rev., v. 227, p. 106-128, 2009.

FREUDL, R.; COLE, S. T. Cloning and molecular characterization of the ompA gene from Salmonella typhimurium. Eur. J. Biochem., v. 134, p. 497-502, 1983.

FUKUSHIMA, H.; JIMI, E.; OKAMOTO, F.; MOTOKAWA, W.; OKABE, K. IL-1 induced receptor activator of NF-kB ligand i human periodontal ligament cells involves ERK-dependent $\mathrm{PGE}_{2}$ production. Bone, v. 36, p. 267-275, 2005.

GARLET, G. P.; MARTINS, W. Jr.;FERREIRA, B. R.; MILANEZI, C. M.; SILVA, J. S. Patterns of chemokines and chemokines receptors expression in different forms of human periodontal disease. J. Periodont. Res., v. 38, p. 210-217, 2003.

GAYWEE, J.; XU, W.; RADULOVIC, S.; BESSMAN, M. J.; AZAD, A .F. The Rickettsia prowazekii invasion gene homolog (inv A) encodes a nudix hydrolase active on adenosine (5')pentaphospho-(5')-adenosine. Mol. Cell Proteomics, v. 1, p. 179-183, 2002.

GEORGELLIS, D.; KWON, O.; LIN, E. C.; WONG, S. M.; AKERLEY, B. J. Redox signal transduction by the ArcB sensor kinase of Haemophilus influenzae lacking the PAS domain. J. Bacteriol., v. 183, p. 7206-7212, 2001.

GIRARDIN, S. E.; BONECA, I. G.; CARNEIRO, L. A.; ANTIGNAC, A.; JEHANO, M.; VIALA, J.; TEDIN, K.; TAHA, M.K; LABIGNE, A.; ZAHRINGER et al. Nod1 detects a unique muropeptide from gram-negative bacterial peptidoglican. Science, v. 300, p. 1584-1587, 2003.

GIRARDIN, S. E., TOURNEBIZE, R.; MAVRIS, M.; PAGE, A. L.; LI, X.; STARK, G. R.; BERTIN, J.; DiSTEFANO, P. S.; YANIV, M.; SANSONETTI, P. J.; PHILPOTT, D. J. CARD4/NOD1 mediates NF-kB and JNK activation by invasive Shiguella flexneri. EMBO Rep., v. 2, p. 736-742, 2001. 
GORJALA, P.; GARY, R. K. Beryllium sulfate induces $\mathrm{p} 21^{\text {CDKN1A }}$ expression and a senescencelike cell cycle arrest in a susceptible cancer types. Biometals, 2010, doi: 10.1007/s10534-0109352-y

GOWEN, M.; WOOD, D. D.; IHRIE, E. J.; McGUIRE, M. K.; RUSSEL, R. G. An interleukin-1 like factor stimulates bone resorption in vitro. Nature, v. 306, p. 378-380, 1983.

GRAVES, D. T.; OSKUI, M.; VOLEJNIKOVA, S.; NAGUIB, G.; CAI, S.; DETA, T.; KAKOURAS, A.; JIANG, Y. Tumor necrosis factor modulates fibroblast apoptosis, PMN recruitment and osteoclast formation in response to $P$. gingivalis infection. J. Dent.Res., v. 80, p. 1875-1879, 2001.

GRAVES, D. Cytokines that promote periodontal tissue destruction. J. Periodontol., v.79, p.1585-1591, 2008.

HAASE, E. M.; ZMUDA, Z. L.; SCANNAPIECO, F. A. Identification and molecular analysis of rough-colony-specific outer membrane proteins of Actinobacillus actinomycetemcomitans. Infect. Immun., v. 67, p .2901-2908, 1999.

HAASE, E. M.; STREAM, J. O.; SCANNAPIECO, F. A. Transcriptional analysis of the 5' terminus of the flp fimbrial gene cluster from Actinobacillus actinomycetemcomitans. Microbiology, v. 149, p. 206-216, 2003.

HAN, X.; LIN, X.; SEliGER, A. R.; EASTCOTT, J.; KAWAI, T.; TAUBMAN, M. A. Expression of receptor activator of nuclear factor-kappaB ligand by $\mathrm{B}$ cells in response in response to oral bacteria. Oral Microbiol. Immunol., v. 24, p. 190-196, 2009.

HANDFIELD, M.; BRADY, L. J.; PROGULSE-FOX, A.; HILLMAN, J. D. IVIAT: a novel method to identify microbial genes expressed specifically during human infections. Trends Microbiol., v. 8, p. 336-338, 2000.

HANDFIELD, M.; MANS, J. J.; ZHENG, G.; LOPEZ, M. C.; MAO, S.; PROGULSKE-FOX, A.; NARASIMHAN, G.; BAKER, H. V.; LAMONT, R. J. Distinct transcriptional profiles characterize oral epithelium-microbiota interactions. Cell. Microbiol., v. 7, p. 811-823, 2005.

HASEGAWA, Y.; TRIBBLE, G. D.; BAKER, H. V.; MANS, J. J.; HANDFIELD, M.; LAMONT, R. J. Role of Porphyromonas gingivalis SerB in gingival epithelial cell cytoskeletal remodeling and cytokine production. Infect. Immun., v. 76, p. 2420-2427, 2008.

HENDERSON, B.; NAIR, S. P.; WARD, J. M.; WILSON, M. Molecular pathogenicity of the oral opportunistic pathogen Actinobacillus actinomycetemcomitans. Annu. Rev. Microbiol., v. 57, p. 29-55, 2003. 
HODGE, J. M.; KIRKLAND, M. A.; AITKEN, C. J.; WAUGH, C. M.; DAMIAN, E. M; LOPEZ, C. M.; ADAMS, B. E, NICHOLSON, G. C. Osteoclastic potential of human CFU-GM: Biphasic effect of GM-CSF. J. Bone Mineral Res., v. 19, p. 190-199, 2004a

HODGE, J. M.; KIRKLAND, M. A.; NICHOLSON, G. C. GM-CSF cannot substitute for MCSF in human osteoclastogenesis. Bioch. Biophys. Res. Commun., v. 321, p. 7-12, 2004b.

HUANG, G. T.; ZHANG, H. B.; DANG, H. N; HAAKE, S. K. Differential regulation of cytokine genes in gingival epithelial cells challenge by Fusobacterium nucleatum and Porphyromonas gingivalis. Microb. Pathog., v. 37, p. 303-312, 2004.

INOHARA, N.; KOSEKI, T.; DEL PESO, L.; HU, Y.; YEE, C.; CHEN, S. Nod1, an Apaf-1 like activator of caspase-9 and nuclear factor kappaB. J. Biol. Chem., v. 274, p. 14560-14567, 1999.

ISHIHARA, Y.; NISHIHARA, T.; MAKI, E.; NOGUSHI, T.; KOGA, T. Role of interleukin-1 and prostaglandin in vitro bone resorption induced by Actinobacillus actinomycetemcomitans lipopolysaccharide. J. Periodontal Res., v. 26, p. 155-160, 1991.

ISMAIL, T. M.; HARTS, C. A.; McLENNAN, A. G. Regulation of dinucleoside polyphosphate pools by the ygdh and apaH hydrolases is essential for the ability of Salmonella enterica serovar Typhimurium to invade cultured mammalian cells. J. Biol. Chem., v. 278, p. 32602-32607, 2003.

IQBAL, J.; SUN, L.; ZAID, M. Complexity in signal transduction. Annu. N. Y. Acad. Sci., v. 1192, p. 238-244, 2010.

JANEWAY, C. Jr.; MEDZHITOV, R. Innate immune recognition. Annu. Rev. Immunol., v.20, p. 197-216, 2002.

JUNTILLA, M. R.; LI, S. P.; WESTERMACK, J. Phosphatase-mediated crosstalk between MAPK signaling pathways in the regulation of cell survival. FASEB J., v. 22, p. 954-965, 2008.

KACHLANY, S. C.; PlANET, P. J.; BHATTACHAJEE, M. K.; KOLLIA, E.; De SALLE, R.; FINE, D. H; FIGURSKI, D. H. Nonspecific adherence by Actinobacillus actinomycetemcomitans requires genes widespread in bacteria and archaea. J. Bacteriol., v. 182, p. 6169-76, 2000.

KACHLANY, S. C.; PLANET, P. J.; DeSALLE, R.; FINE, D. H.; FIGURKI, D. H.; KAPLAN, J. B. $f l p-1$, the first representative of a new pilin gene subfamily, is required for non-specific adherence of Actinobacillus actinomycetemcomitans. Mol. Microbiol., v. 40, p. 542-554, 2001.

KACHLANY, S. C. Aggregatibacter actinomycetemcomitans leukotoxin: from threat to therapy. J. Dent. Res., 2010 (in press). doi: 10.1177/0022034510363682 
KAPLAN, J. B; PERRY, M. B; MACLEAN, L. L; FURGANG D.; WILSON, M. E; FINE D. H. Structural and genetic analyses of $\mathrm{O}$ polysaccharide from Actinobacillus actinomycetemcomitans serotype f. Infect. Immun., v. 69, p. 5375-5384, 2001.

KAPLAN, J. B.; KOKEGUCHI, S.; MURAYAMA, Y.; FINE, D. H. Sequence diversity in the major fimbrial subunit gene (flp-1) of Actinobacillus actinomycetemcomitans. Oral Microbiol. Immunol., v. 17, p. 354-359, 2002.

KAPLAN, J. B.; SCHREINER, H. C.; FURGANG, D.; FINE, D. H.Population structure and genetic diversity of Actinobacillus actinomycetemcomitans strains isolated from localized juvenile periodontitis patients. J. Clin. Microbiol., v. 40, p. 1181-1187, 2002b.

KAPLAN, J. B.; MEYENHOFER, M. F.; FINE, D. A. Biofilm growth and detachment of Actinobacillus actinomycetemcomitans. J. Bacteriol., v. 185, p. 1399-1404, 2003.

KAPLAN, J. B.; VELliYAGOUNDER, K.; RAGUNATH, C.; ROHDE, H.; MACK, D.; KNOBLOCK, J. K.; RAMASUBBU, N. Genes involved in the syntesis and degradation of matrix polysaccharide in Actinobacillus actinomycetemcomitans and Actinobacillus pleuropneumoniae biofilms. J Bacteriol., v. 186, p. 8213-8220, 2004.

KARCHED, M.; SATYASEELA, P. M.; ASIKAINEN, S. A simple viability-maintaining method produces homogenic cell suspensions of autoaggregating wild-type Actinobacillus actinomycetemcomitans. J. Microbiol. Methods., v. 68, p. 46-51, 2007.

KAWAI, T.; MATSUYAMA, T.; HOSOKAWA, Y.et al. B and T lymphocytes are the primary sources of RANKL in the bone resorptive lesion of periodontal disease. Am. J. Pathol., v. 169, p. 987-999, 2006.

KAWAMOTO, D.; ANDO, E. S.; LONGO, P. L.; NUNES, A. C.; WIKSTRÖM, M.; MAYER, M. P. Genetic diversity and toxic activity of Aggregatibacter actinomycetemcomitans isolates. Oral. Microbiol. Immunol., v. 24, p. 493-501, 2009.

KAWANO, H.; NAKATANI, T. ; MORI, T. ; UENO, S. ; FUKAYA, M. ; et al. Identification and characterization of novel development regulates neural-specific proteins, BRINP family. Mol. Brain. Res. v. 12, p. 60-75, 2004.

KIKKERT, R.; LAINE, M. L.; AARDEN, L.A.; VAN WINKELHOFF, A. J. Activation of tolllike receptors 2 and 4 by gram-negative periodontal bacteria. Oral Microbiol. Immunol., v. 22, p.145-151, 2007

KIKUCHI, T.; HAHN, C. L.; TANAKA, S.; BARBOUR, S. E.; SCHENKEIN, H. A.; TEW, J. G. Dendritic cells stimulated with Actinobacillus actinomycetemcomitans elicit rapid gamma interferon responses by natural killer cells. Infect. Immun., v. 72, p. 5089-5096, 2004. 
KIRKWOOD, K. L.; ROSSA, C. Jr. The potential of p38 MAPK inhibitors to modulate periodontal infectious. Curr. Drug Metabolism., v. 10, p. 1-12, 2009

KOLODRUBETZ, D.; DAILEY, T.; EBERSOLE, J.; KRAIG, E. Cloning and expression of the leucotoxin gene from Actinobacillus actinomycetemcomitans. Infect. Immun., v. 57, p. 1465$1469,1989$.

KOMATSUZAWA, H.; KAWAI, T.; WILSON, M. E.; TAUBMAN, M.A.; SUGAI, M.; SUGINAKA, H. Cloning of the gene enconding of Actinobacillus actinomycetemcomitans serotype b OmpA-like outer membrane protein. Infect. Immun., v. 67, p. 942-945, 1999.

KOMATSUZAWA, H.; ASAKAWA, R.; KAWAI, T.; OCHIAI, K.; FUJIWARA, T.; TAUBMAN, M. A.; OHARA, M.; KURIHARA, H.; SUGAI, M. Identification of six major outer membrane proteins from Actinobacillus actinomycetemcomitans. Gene. v. 17, p. 195-201, 2002.

KRISANAPRAKORNKIT, S.; KIMBALL, J. R.; WEINBERG, A.; DARVEAU, R. P.; BAINBRIDGE, B. W.; DALE, B. A. Inducible expression of human beta-defensin 2 by Fusobacterium nucleatum in oral epithelial cells: multiple signaling pathways and role commensal bacteria in innate immunity and the epithelial barrier. Infect. Immun., v. 68, p. 2907-2915, 2000.

KUSUMOTO, Y.; HIRANO, H.; SAITOH, K.; YAMADA, S.; TAKEDACHI, M.; NOZAKI, T. et al. Human gingival epithelial cells produce chemotactic factors interleukin-8 and monocyte chemoattractant protein-1 after stimulation with Porphyromonas gingivalis via toll-like receptors 2. J. Periodontol., v.74, p. 370-379, 2004.

LALLY, E. T.; KIEBA, I. R.; DEMUTH, D. R.; ROSENBLOOM, J.; GOLUB, E. E.; TAICHMAN, N. S.; et al. Identification and expression of the Actinobacillus actinomycetemcomitans leukotoxin gene. Bioch. Biophys. Res. Commun., v. 159, p. 256-262, 1989.

LÉVÊQUE, F.; BLANCHIN-ROLAND, S.; FAYAT, G.; PLATEAU, P.; BLANQUET, S. Desing an characterization of Escherichia coli mutants devoid of Ap4N-hydrolase activity. J. Mol. Biol., v. 212, p. 319-329, 1990.

LEE, S.; HARRIS, S. E.; ROODMAN, G. D.; SPRAGUE, E.; BONEWALD, L. F.; Chemotaxis a potential mechanism whereby osteocytes target osteoclasts precursors to bone. J. Bone Miner Res. 15 (1 Suppl): 208, 2000.

LI, L.; MATEVSKI, D.; ASPIRAS, M.; ELLEN, R. P.; LEPINE, G. Two epithelial cell invasion-related loci of the oral pathogen Actinobacillus actinomycetemcomitans. Oral Microbiol. Immunol., v. 19, p. 16-25, 2004. 
LONGO, P. L. Construção, análise de fenótipo e da transcrição gênica de uma amostra mutante de Aggregatibacter actinomycetemcomitans deficiente em $\operatorname{arcB}$. São Paulo. [Tese (Doutorado) - Instituto de Ciências Biomédicas da Universidade de São Paulo], 111 p, 2008

LU, X.; MASIC, A.; LI, Y.; SHIN, Y.K.; LIU, Q.; ZHOU, Y. The pI13K/Akt pathway inhibits influenza A virus induced Bax-mediated apoptosis by negatively regulating the JNK pathway via ASK. J. Gen. Virol., v. 91, p. 1439-1449, 2010.

MARANDI, M; MITTAL, K. R. Characterization of an outer membrane protein of Pasteurella multocida belonging to the OmpA family. Vet. Microbiol., v. 53, p. 303-314, 1996.

MAYER, M. P. A.; BUENO, L. C.; HANSEN, E. J.; DIRIENZO, J. M. Identification of a cytolethal distending toxin gene locus and features of a virulence associated region in Actinobacillus actinomycetemcomitans. Infect. Immun., v. 67, p. 1227-1237, 1999.

McBRIDE, H. M.; NEUSPIEL, M.; WASIAK, S. Morw than just a powerhouse. Curr. Biol., v. 16, p. 551-560, 2006.

MERIACHTCHERIAKOVA， D.; SCHABBAUER， G.; LUCERNA， M.; CLAUSS, M.; MARTIN, R., BINDER, B. R.; HOFER, E. Specificity, diversity, and convergence in VEGF and TNF- $\alpha$ signaling events leading to tissue factor upregulation via EGR-1 in endothelail cells. FASEB J., v. 15, p. 230-242, 2001

MEYER, D. H. SREENIVASAN, P. K. FIVES-TAYLOR, P. M. Evidence for invasion of a human oral cell line Actinobacillus actinomycetemcomitans. Infect. Immun., v. 59, p. 27192726, 1991.

MEYER, D. H; FIVES-TAYLOR, P. M. Characteristics of adherence of Actinobacillus actinomycetemcomitans to epithelial cells. Infect. Immun., v. 62, p. 928-935, 1994

MEYER, D. H.; FIVES-TAYLOR, P. M. Models of invasion of enteric and periodontal pathogens into epithelial cells. A comparative analysis. Crit. Rev.Oral Biol. Med., v. 8, p. 389409, 1997.

MILWARD, M. R.; CHAPLE, I. L. C.; WRIGHT, H. J.; MILLARD, J. L.; MATTHEWS, J. B.; COOPER, P. R. Differential activation of NF-kB and gene expression in oral epithelial cells by periodontal pathogens. Clin. Exp.Immunol., v. 148, p. 307-324. 2007;

MINTZ, K. P.; FIVES-TAYLOR, P. M. Adhesion of Actinobacillus actinomycetemcomitans to a human oral cell line. Infect Immun., v. 62, p. 3672-8, 1994. 
MINTZ, K. P. Identification of an extracellular matrix protein adhesion, EmaA, which mediates the adhesion of Actinobacillus actinomycetemcomitans to collagen. Microbiology, v. 150, p. 2677-2688, 2004.

MITCHELL, S. J.; MINNICK, M. F. Characterization of two-gene locus from Bartonella bacilliformis associated with the ability to invade human erythrocytes. Infect. Immun., v. 63, p. 1552-1562.l, 1995.

MITCHELL, C.; GAO, L.; DEMUTH, D. R. Positive and negative cis-acting regulatory sequences control expression of leukotoxin in Actinobacillus actinomycetemcomitans. Infect. Immun., v. 71, p. 5640-5649, 2003.

MITTAL, R.; PRASADARAO, N. V. Outer membrane protein A expression in Escherichia coli K1is required to prevent the maturation of myeloid dendritic cells and the induction of IL-10 and TGF- $\beta$. J. Immunol., v. 181, p. 2672-2682, 2008.

MIYASAKI, K. T.; WILSON, M. E.; REYNOLDS, H. S.; GENCO, R. J. Resistence of Actinobacillus actinomycetemcomitans and differential susceptibility of oral Haemophilus species to the bactericidal effects of hidrogen peroxide. Infect. Immun., v. 46, p. 644-648, 1984.

MOLTÓ, A.; OLIVÉ, A. Anti-IL-1 molecules: new comers and new indications. Joint Bone Spine, v. 77, p. 102-107, 2010.

MUHLE, I.; RAU, J.; RUSKIN, J. Vertebral osteomyelitis due to Actinobacillus actinomycetemcomitans. JAMA, v. 241, p. 1824-1825, 1979.

MUNSON, R. S. Jr; GRASS, S.; WEST, R. Molecular cloning and sequence of the gene for outer membrane protein P5 of Haemophilus influenza. Infect Immun., v. 61, p. 4017-4020, 1993.

MUTHUSAMY, V.; PIVA, Y. J. The UV response of the skin: a review of the MAPK, NFkB and TNF $\alpha$ signal transduction pathways. Arch. Dermatol. Res., v. 302, p. 5-17, 2010.

NAIDU, K. A.; FANG, Q.; NAIDU, A. A.; CHENG, J. Q.; NICOSIA, S. V.; COPPOLA, D. p53 enhances ascorbyl stearate-induced G2/M arrest of human cancer cells. Anticancer Res., v. 27, p. 3927-3934, 2007

NALBANT, A.; CHEN, C.; WANG, Y.; ZADEH, H. H. Induction of T-cell apoptosis by Actinobacillus actinomycetemcomitans mutants with delection of 1txA and cdtABC genes: possible activity of GroEL-like molecule. Oral Microbiol. Immunol., v. 18, p. 339-349, 2003.

NIKAIDO, H.; WU, H. C. P. Amino acid sequence homology among the major outer membrane proteins of Escherichia coli. Proc. Natl. Acad. Sci., v. 81, p. 1048-1052, 1984. 
NISHIDA, E.; HARA, Y.; KANEKO, T.; IKEDA, Y.; UKAI, T, KATO, I. Bone resorption and local interleukin1-alpha and interleukin1-beta synthesis induced by Actinobacillus actinomycetemcomitans and Porphyromonas gingivalis lipopolysaccharide. J. Periodontal Res., v. 36, p. $1-8,2001$.

NOGUSHI, T.; SHIBA, H.; KOMATSUZAWA, H.; MIZUNO, N.; UCHIDA, Y.; OUHARA, K.; ASAKAWA, R.; KUDO, S.; KAWAGUSHI, H.; SUGAI, M.; KURIHARA, H. Syntesis of prostaglandin E2 and E-cadherin and gene expression of beta defensin2 by human gingival epithelial cells in response to Actinobacillus actinomycetemcomitans. Inflammation, v. 27, p. 341-349, 2003.

NOMURA, K,; KURODA, S.; YOSHIKAWA, H.; TOMITA, T. Inflammatory osteoclastogenisis can be induced by GM-CSF and activated under TNF immunity. Bioch. Biophys. Res. Commun., v. 367, p. 881-887, 2008.

NORSKOV-LAURITSEN, N.; KILIAN, M. Reclassification of Actinobacillus actinomycetemcomitans, Haemophilus aphrophilus, Haemophilus paraphrophilus and Haemophilus segnis as Aggregatibacter actinomycetemcomitans gen. nov., comb.nov., Aggregatibacter aphrophilus comb. nov., and Aggregatibacter segnis comb. nov., and emended description of Aggregatibacter aphrophilus to include V factor-dependent and V factorindependent isolates. Int. J. Syst. Evol. Microbiol., v. 56, p. 2135-2146, 2006

O’DEA, E.; HOFFMANN, A. NF-kB signaling. Wiley Interdiscipli. Rev. Syst. Biol. Med., v.1, p. 1-13, 2009.

OGURA, K.; MAEDA, S.; NAKAO, M.; WATANABE, T.; TADA, M.; KYUTOKU, T.; YOSHIDA, H.; SHIRATORI, Y.; OMATA, M. Virulence factors of Helicobacter pylori responsible for gatric diseases in Mongolian gerbil. J. Expr. Med., v. 192, p. 161-1610, 2000.

OPITZ, B.; PUSHEL, A.; BEERMANN, W.; HOCKE, A. C.; FOSTER, S.; SCHMECK, B.; VAN LAAK, V.; CHAKRABORTY, T.; SUTTORP, N.; HIPPENSTIEL, S. Listeria monocytogenes activated p38 MAPK and induced IL-8 secretion in a nucleotide-binding oligomerization domain 1-dependent manner in endothelial cells. J. Immunol., v. 176, p. 484490, 2006.

OUHARA, K.; KOMATSUZAWA, H.; SHIBA, H.; UCHIDA, Y.; KAWAI, T.; SAYAMA, K.; HASHIMOTO, K.; TAUBMAN, M. A.; KURIHARA, H.; SUGAI, M. Actinobacillus actinomycetemcomitans outer membrane protein 100 triggers innate immunity and production of beta-defensin and the 18-kilodalton cationic antimicrobial protein through the fibronectinintegrin pathway in human gingival epithelial cells. Infect. Immun., v. 74, p. 5211-5220, 2006.

PAGE, M. I.; KING, E. O. Infection due to Actinobacillus actinomycetemcomitans and Haemophilus aphrophilus. New Eng. J. Med., v. 275, p. 181-188, 1966. 
PAJU, S.; SAARELA, M.; ALALUUSUA, S.; FIVES-TAYLOR, P.; AISIKAINEN. Characterization of Serologically Nontypeable Actinobacillus actinomycetemcomitans Isolates. J. Clin. Microbiol., v. 7, p. 2019-2022, 1998.

PANAGAKOS, F. S.; HINOJOSA, L. P.; KUMAR, S. Formationa and mineralization of extracellular matrix secreted by an immortal human osteoblatic cell line: modulation by tumor necrosis factor-alpha. Inflammation, v. 18, p. 267-284, 1994.

PATUREL, L.; CASAlTA, J. P.; HABIB, G.; NEZRI, M.; RAOULT, D. Actinobacillus actinomycetemcomitans endocarditis. Clin. Microbiol. Infect., v. 10, p. 98-118, 2004.

PEREZ, B. A.; PLANET, P. J.; KACHLANY, S. C.; TOMICH, M.; FINE, D. H.; FIGURSKI, D. H. Genetic analysis of the requirement for $f l p-2$, $t a d V$ and $r c p B$ in Actinobacillus actinomycetemcomitans biofilm formation. J. Bacteriol., v. 188, p. 6361-6375, 2006.

PFAFLL, M. W.; HORGAN, G. W.; DEMPFLE, L. Relative expression software tool (REST) for group wise comparison and statistical analysis of relative expression results in real-time PCR. Nucleic Acids Res., v. 30, p. 9-36, 2002.

PIMIENTA, G.; PASCUAL, J. Canonical and alternative MAPK signaling. Cell Cycle, v. 6, p. 2628-2632, 2007.

PINHEIRO, E. T.; KAWAMOTO, D.; OTA-TSUZUKI, C.; CARVALHO, A.; ALMEIDA, L. R. S.; NUNES, A. C. R.; LONGO, P. L.; WIKSTROM, M.; MAYER, M. P. A. Analysis of genotypic variation in genes associated with virulence in Aggregatibacter actinomycetemcomitans clinical isolates. Mol. Oral Microbiol., 2010 (submetido)

PIZARRO-CERDA, J.; COSSART, P. Bacterial adhesion and entry into host cells. Cell, v. 124, p. 715-727, 2006.

PRASADARAO, N. V.; WASS, C. A.; KIM, K. S. Endothelial cell GlcNAc epitopes for outer membrane protein A enhance traversal of Escherichia coli across the blood-brain barrier. Infect. Immun., v. 64, p. 254-160, 1996.

PRITCHARD, M. T.; ROYCHOWDHURY, S.; McMULLEN, M. R.; GUO, L.; ARTEEL, G. E.; NAGY, L. E. Am. J. Physiol. Gastrointest. Liver Physiol., v. 293, p. 1124-1133, 2007.

PULENDRAN, B.; KUMAR, P.; CUTLER, C. W.; MOHAMADZEDEH, M.; VAN DYKE, T.; BANCHAREAU, J. Lipopolysaccharides from distinct pathogens induce different classes of immune responses in vivo. J. Immunol., v. 167, p. 5067-5073, 2001. 
RABIN, S. D.; FLITTON, J. G.; DEMUTH, D. R. Aggregatibacter actinomycetemcomitans cytolethal distending toxin induces apoptosis in nonproliferatng macrophages by a phosphataseindependent mechanism. Infect. Immun., v. 77, p. 3161-3169, 2009.

RAMASUBBU, N.; THOMAS, L. M.; RAGUNATH, C.; KAPLAN, J. B. Structural analysis of dispersin $\mathrm{B}$, a biofilm-releasing glycoside hydrolase from the periodontopathogen Actinobacillus actinomycetencomitans. J. Mol. Biol., v. 349, p. 75-486, 2005.

RE, F.; STROMINGER, J. L. Toll-like receptor 2(TLR2) and TLR4 differentially activate human dendritic cells. J. Biol. Chem., v. 276, p. 37692-37690, 2001.

RICHARDSON, J.; CRAIGHEAD, J. C.; CAO, S. L.; HANDFIELD, M. Concurrence between the gene expression pattern of Actinobacillus actinomycetemcomitans in localized aggressive periodontitis and in human epithelial cells. J. Med. Microbiol., v. 54, p. 497-504, 2005.

ROBERTS, F. A.; McCAFFERY, K. A.; MICHALEK, S. M. Profile of cytokine mRNA expression in chronic adult periodontitis. J. Dent. Res., v. 76, p. 1808-1814, 1997.

ROSE, J. E.; MEYER, D. H.; FIVES-TAYLOR, P. M. Aae, an autotransporter involved in adhesion of Actinobacillus actinomycetemcomitans to epithelial cells. Infect. Immun., v. 71, p. 2384-2393, 2003.

SAARELA, M.; AISIKAINEN, S.; ALALUUSUA, S.; PYHÃLÃ, L.; LAI, C. H.; JOUSIMIESSOMER, H. Frequency and stability of mono-and ply-infection by Actinobacillus actinomycetemcomitans serotypes a, b, c, d or e . Oral Microbiol. Immunol., v. 7, p. 277-279, 1992.

SAARELA, M.; ASIKANEN, S.; ALALUUSUA, S.; FIVES-TAYLOR, P. M. apaH Polimorphism in clinical Actinobacillus actinomycetemcomitans isolates. Clin. Microbiol., v. 4, p. 139-144, 1998.

SAARELA, M.; LIPPMAN, J. E.; MEYER, D. H.; FIVES-TAYLOR, P. M. The Actinobacillus actinomycetemcomitans apaH gene is implicated in invasion of epithelial cells. J. Dent. Res., v. 78 (Spec. issue): 1225, 1999.

SANDROS, J.; KARLSSON, C.; LAPPIN, D. F.; MADIANOS, P. N.; KINANE, D. F.; PAPANOU, P. N. Cytokine response of oral epithelial cells to Porphyromonas gingivalis infection. J. Dent. Res., v. 79, p. 1808-1814, 2000.

SATO, T.; KOSEKI, T.; YAMATO, K.; SAIKI, K.; KONISHI, K.; YOSHIKAWA, M.; ISHIKAWA, I.; NISHIHARA, T. p-53-independent expression of p-21CIP/WAF1 in plasmacytic cells during G2 cell cycle arrest induced by Actinobacillus actinomycetemcomitans cytolethal distending toxin. Infect. Immun., v. 70, p. 528-534, 2002. 
SCANNAPIECO, F. A., MILLAR, S. J.; REYNOLDS, H. S.; ZAMBON, J. J.; LEVINE, M. J. Effects of anaerobiosis on the surface proteins of Actinobacillus actinomycetemcomitans (Haemophilus actinomycetemcomitans). Infect. Immun., v. 55, p. 2320-2323, 1987.

SCANNAPIECO, F. A.; WANG, B.; SHIAU, H. J. Oral bacteria and respiratory infection: effects on respiratory pathogen adhesion and epithelial cell proinflammatory cytokine production. Ann. Periodontol., v. 6, p. 78-86, 2001.

SCHETT, G. Osteoimmunology in rheumatic diseases. Arthritis Res. Ther., v. 11, p. 210, 2009.

SCHYTTE-BLIX, I. J.; HELGELAND, K.; HVATTUM, E.; LYBERG, T. Lipopolysaccharide from Actinobacillus actinomycetemcomitans stimulates production of interleukin-1beta, tumor necrosis-alpha, interleukin-6 and interleukin-1 receptor antagonist in human whole blood. J. Periodontal Res., v. 34, p. 34-40, 1999.

SEYDEL, F.; GARRIGAN, E.; STUTEVOSS, B.; BELKIN, N.; MAKADIA, B.; CARTER, J.; SHI, J. D, DAVOODI-SEMIROMI, A.; McDUFFIE, M.; LITHERLAND, S. A. GM-CSF induces STAT5 binding at epigenetic regulatory sites within the Csf2 promoter of obese diabetic (NOD) mouse myeloid cells. J. Autoimmun., v. 31, p. 377-384, 2008.

SHALE, M.; GOSH, S. How intestinal epithelial cells tolerise dendritic cells and its relevant to inflammatory bowel disease. Gut, v. 58, p. 1291-1299, 2009.

SHENKER, B. J.; MCKAY, T.; DATAR, S.; MILLER, M.; CHOWHAN, R.; DEMUTH, D. R. Actinobacillus actinomycetemcomitans immunosuppressive protein is a member of the family of cytolethal distending toxins capable of causing a G2 arrest in human T cells. J. Immunol., v. 167, p. 4773-4780, 1999.

SHENKER, B. J.; HOFFMASTER, R. H., McKAY, T. L.; DEMUTH, D. R. Expression of the cytolethal distending toxin (Cdt) operon in Actinobacillus actinomycetemcomitans: evidence that the CdtB protein is responsible for G2 arrest of the cells cycle in human T cells. J. Immunol., v. 165, p. 2612-2618, 2000.

SHENKER, B.; HOFFMASTER, R. H.; ZEKAVAT, A.; YAMAGUCHI, N.; LALLY, E. T.; DEMUTH, D. R. Induction of apoptosis in human $\mathrm{T}$ cells by Actinobacillus actinomycetemcomitans cytolethal distending toxin is a consequence of G2 arrest of the cell cycle. J. Immunol., v. 167, p. 435-441, 2001.

SHIMADA, T.; SUGANO, N.; NISHIHARA, R.; SUZUKI, K.; TANAKA, H.; ITO, K. Differential effects of five Aggregatibacter actinomycetemcomitans strains on gingival epithelial cells. Oral Microbiol. Immunol., v. 23, p. 455-458, 2008. 
SHORTS-CARY, L.; XU, M.; ERTEL, J.; KLEINSCHMIDT-DEMASTERS, B. K.; LILLEHEI, $\mathrm{K}$. et al., Bone morphonegetic protein and retinoic acid-inducible neural specific protein-3 is expressed in gonadotrope cells pituitary adenomas and induces proliferation, migration, and invasion. Endocrinology, v. 148, p. 967-975, 2007.

SILVA, N.; DUTZAN N.; HERNANDEZ, M.; DEZEREGA, A.; RIVERA, O.; AGUILLON, J. C.; ARAVENA, O.; LASTRES, P.; POZO, P.; VERNAL, R.; GAMONAL, J. Characterization of progressive periodontal lesions in chronic periodontits: levels of chemokines, cytokines, matrix metalloproteinase-13, periodontal pathogens and inflammatory cells. J. Clin. Periodontol., v. 35, p. 206-214, 2008.

SKERKER, J. M.; SHAPIRO, L. Identification and cell cycle control of a novel pilus system in Caulobacter crescentus. EMBO J., v. 19, p. 3223-3234, 2000.

SLOTS, J.; GENCO, R. J. Black-pigmented Bacteroides species, Capnocytophaga species, and Actinobacillus actinomycetemcomitans in human periodontal disease: virulence factors in colonization, survival, and tissue destruction. J. Dent. Res., v. 63, p. 412-421, 1984.

SLOTS, J. Bacterial specificity in adult periodontitis. J. Clin. Periodontol., v. 13, p. 912-917, 1986.

SMITH, J. L.;BAYLES, D. O. The contribtion of cytolethal distending toxin to bacterial pathogenisis. Crit. Rev. Microbiol., v. 32, p. 227-248, 2006.

SMITH, S. G. J.; MAHON, V.; LAMBERT, M. A.; FAGAN, R. P. A molecular swiss army knife:OmpA structure, function and expression. FEMS Microbiol Lett., v. 273, p. 1-11, 2007.

SONG, Y. H.; KOZAROV, E. V.; WALTERS, S. M.; CAO, S. L.; HANDFIELD, M.; HILLMAN, J. D.; PROGULSE-FOX, A. Genes of periodontopathogens expressing during human disease. Ann. Periodontol., v. 7, p. 38-42, 2002.

SONTEG, I.; SCHWARZ, H, HIROTA, Y.; HENNING, U. L. F. Cell envelope and shape of Escherichia coli: multiple mutants missing the outer membrane lipoprotein and other major outer membrane proteins. J. Bacteriol., v. 136, p. 280-285, 1978.

SPINATZEL, J. Jr.; KRAIG, E.; KOLODRUBETZ, D. Regulation of leukotoxin in leukotoxic and nonleukotoxic strains of Actinobacillus actinomycetemcomitans. Infect. Immun., v. 59, p. 1394-1401, 1991.

SPINOLA, S. M.; GRIFFITHS, G. E.; SHANKS, K. L.; BLAKE, M. S. The major outer membrane protein of Haemophilus ducreyi is a member of the OmpA family of proteins. Infect. Immun., v. 61, p. 1346-1351, 1993. 
SUGAI, M.; KAWAMOTO, T.; PERES, S. Y.; UENO, Y.; et al. The cell cycle-specific growthinhibitory factor produced by Actinobacillus actinomycetemcomitans is a cytolethal distending toxin. Infect. Immun., v. 66, p. 5008-5019, 1998.

SUGIYAMA, A.; UEHARA, A.; IKI, K.; MATSUSHITA, K.; NAKAMURA, R.; OGAWA, T.; SUGAWARA, S.; TAKADA, H. Activation of human gingival epithelial cells by cell-surface components of blackpigmented bacteria: Augmentation of production of interleukin-8, granulocyte colony stimulating factor and granulocyte-macrophage colony-stimulating factor and expression of intercellular adhesion molecule 1. J Med Microbiol., v. 51, p. 27-33, 2002.

TAKAHASHI, N.; KOBAYASHI, M.; TAKAKI, T.; TAKANO, K.; MIYATA, M.; OKAMATSU, Y.; HASEGAWA, K.; NISHIHARA, T.; YAMAMOTO, M. Actinobacillus actinomycetemcomitans lipopolysaccharide stimulates collagen phagocytosis by human gingival fibroblasts. Oral Microbiol. Immunol., v. 23, p. 259-264, 2008.

TAKANAYAGI, H.; KIM, S.; MATSUO, K.; SUZUKI, H.; SUZUKI, T.; SATO., K.; YOKOSHI,T.; ODA, H.; NAKAMURA, K.; IDA, N.; WAGNER, E. F.; TANIGUSHI, T. RANKL maintains bone homeostasis though c-Fos dependent induction of interferon- $\beta$. Nature, v. 416, p. 744-749, 2002.

TAKEDA, K.; KAISHO, T.; AKIRA, S. Toll-like receptors. Annu. Rev. Immunol., v. 21, p. 335-376, 2003.

TANCHAROEN, S.; MATSUYAMA, T.; ABEYAMA, K.; MATSUSHITA, K.; KAWAHARA, K.; SANGALUNGKARN, V.; TOKUDA, M.; HASHIGUSHI, T.; MARUYAMA, I.; IZUMI, Y. The role of water channel Aquaporin 3 in the mechanism of TNF- $\alpha$ mediated proinflammatoy events: implication in periodontal inflammation. J. Cell Phisiol., v. 217, p. 38-349, 2008

TANG, P.; FOUBISTER, V.; PUCCIARELlI, M. G.; FINLAY, B. B. Methods to study of bacterial invasion. J. Microbiol. Methods, v. 18, p. 227-240, 1993.

TENG, Y. T. A.; HU, W. Expression cloning of a periodontits-associated apoptotic efector, cage homologue, in Actinobacillus actinomycetemcomitans. Bioch. Biophys. Res. Commun., v. 303, p. 1086-1094, 2003.

TIRANATHANAGUL, S. ; YONGCHAITRAKUL, T. ; PATTAMAPUN, K. ; PAVASANT, P. Actinobacillus actinomycetemcomitans lipopolysaccharide activates matrix metalloproteinase-2 and increases receptor activator of nuclear factor-kappa ligand expression in human periodontol ligament cells. J. Periodontol., v. 75, p. 1647-1654, 2004.

TOMICH, M.; FINE, D. H.; FIGURSKI, D. H. The TadV of Actinobacillus actinomycetemcomitans is a novel aspartic acid prepilin peptidase required for maturation of the Flp1 pilin and TadE and TadF pseudopilins. J. Bacteriol., v. 188, p. 6899-6914, 2006. 
TOMICH, M.; PLANET, P. J.; FIGURSKI, D. H. The tad locus: postcards from the widespread colonization island. Nat. Rev. Microbiol., v. 5, p. 363-375, 2007.

TRABANDT, A.; GAY, R. E.; SUKHATME, V. P.; GAY, S. Expression of collagenase and potential transcriptional factors c-fos and egr-1 in periodontal gingival fibroblasts. J. Oral Pathol. Med., v. 21, p. 232-240, 1992.

TYLER, C. D.; LICHTI, C. F.; DIEKMAN, A. B.; FOLEY, S. L. Evaluation of differentially expressed proteins following serum exposure in avian pathogenic Escherichia coli. Avian Dis., v. 52, p. 23-27, 2008.

UEHARA, A.; FUJIMOTO, Y.; FUKASE, K.; HARUHIKO, T. Various human epithelial cells express functional Toll-like receptors, NOD1 and NOD2 to produce anti-microbial peptides, but not proinflammatory cytokines. Mol. Immunol., v. 44, p. 3100-3111, 2007.

UEKI, K.; FRUMAN, D. A.; BRACHMANN, S. M.; TSENG, Y. H.; CANTLEY, L. C.; KAHN, R. Molecular balance between the regulatory and catalytic subunits of phosphoinositide 3-kinase regulates cells sigmailng and survival. Mol. Cell. Biol., v. 22, p. 965-977, 2002.

WANG Y. The function of OmpA in Escherichia coli. Bioch. Biophys. Res. Comm., v. 292, p. 396-401, 2002

WANG, Y.; LIU, A.; CHEN, C. Genetic basis for conversion of rough-to-smooth colony morphology in Actinobacillus actinomycetemcomitans. Infect. Immun., v. 73, p. 3749-3753, 2005.

WEI, S.; KITAURA, H.; ZHOU, P. et al. IL-1 mediates TNF-induced osteoclastogenesis. J. Clin. Invest., v. 115, p. 282-290, 2005.

WEISER, J. N.; GOTSCHLICH, E. C. Outer membrane protein A (OmpA) contributes to serum resistance and patogenicity. of Escherichia coli K-1. Infect. Immun., v. 59, p. 2252-2258, 1991.

WILSON, M. E. The heat modifiable outer membrane protein of Actinobacillus actinomycetemcomitans : relationship to ompA proteins. Infect. Immun., v. 59, p. 2505-2507, 1991a.

WILSON, M. IgG antibody response of localized juvenile periodontits patients to the 29 kilodalton outer membrane protein of Actinobacillus actinomycetemcomitans. J. Periodontol., v. 62, p. 211-218, 1991 b.

WILSON, M.; HENDERSON, B. Virulence factors of Actinobacillus actinomycetemcomitans relevant to the pathogenesis of inflammatory periodontal disease. FEMS Microbiol. Rev., v. 17, p. 365-379, 1995. 
WU, H. H.; YANG, Y. Y.; HSIEH, W. S.; LEE, C. H.; LEU, S. J.; CHEN, M. R. OmpA is the critical component for Escherichia coli invasion-induced astrocyte activation. J. Neuropathol. Exp. Neurol., v. 68, p. 677-690, 2009.

VIALA, J. C.; CHAPUT. A.; BONECA, I. G.; CARDONA, A.; GIRARDIN, S. E.; MORAN, S.; HUERRE, M. R.; COYLE, A. J. Nod1 responds to peptidoglican delivered by the Helicobacter pylori cag pathogenicity island. Nat. Immunol., v. 5, p. 1166-1174, 2004.

YAMAMOTO, M.; TAKEDA, K. Role of nuclear IkB proteins in the regulation of host immune response. J. Infect. Chemother., v. 14, p. 265-269, 2008.

YANG, H. W.; AISIKAINEM, S.; DOGAN, B.; SUDA, R.; LAI, C. H. Relationship of Actinobacillus actinomycetemcomitans serotype $\mathrm{b}$ to aggressive periodontitis: frequency and pure culture isolates. J. Periodontol., v. 75, p. 592-599, 2004

YILMAZ, O.; SATER, A. A.; YAO, L.; KOUTOUZIS, T.; PETTENGILL, M.; OJCIUS, D. M. ATP-dependent activation of an inflammasome in primary gingival epithelial cells infected by Porphyromonas gingivalis. Cell. Microbiol., v. 12, p. 188-198, 2010.

YUE, G.; KAPLAN, J. B.; FURGANG, D.; KEITH, G. M.; FINE, D. H. A second Aggregatibacter actinomycetemcomitans autotransporter adhesion exhibits specificity for buccal epithelial cells in humans and old world primates. Infect. Immun., v. 75, p. 4440-4448, 2007

YUE, G., KAPLAN, J. B.; FINE, D. H. A motif in aae mediates binding to BECS and endothelium. 87 $^{\text {th }}$ General Session and Exhibition of the IADR, Abst 1683. Miami., 2009.

ZAMBON, J. J. Actinobacillus actinomycetemcomitans in human periodontal disease. J. Clin. Periodontol., v. 12, p. 1-20, 1985. 
ANEXO A- Arranjo dos 96 pares de iniciadores da via de transdução de sinais de célula humana do kit $\mathrm{RT}^{2}$ Profiler PCR Array Human Signal Transduction PathwayFinder (PAHS-014A)

\begin{tabular}{|c|c|c|c|}
\hline Posição & Gen Bank & Símbolo & Descrição \\
\hline A01 & NM_001880 & ATF2 & Activating transcription factor 2 \\
\hline A02 & NM_004324 & BAX & BCL2-associated X protein \\
\hline A03 & NM_000633 & BCL2 & B-cell CLL/lymphoma \\
\hline A04 & NM_004049 & BCL2A1 & BCL2-related protein A \\
\hline A05 & NM_138578 & BCL2L1 & BCL2like 1 \\
\hline A06 & NM_004536 & NAIP & NLR family, apoptosis inhibitory protein \\
\hline A07 & NM_001166 & BIRC2 & Baculoviral IAP repeated-containing 2 \\
\hline A08 & NM_001165 & BIRC3 & Baculoviral IAP repeated-containing 3 \\
\hline A09 & NM_001200 & BMP2 & Bone morphogenetic protein 2 \\
\hline A10 & NM_001202 & BMP4 & Bone morphogenetic protein 4 \\
\hline A11 & NM_007294 & BRCA1 & Breast cancer 1 , early onset \\
\hline A12 & NM_002982 & CCL2 & Chemokine(C-C motif) ligand 2 \\
\hline B1 & NM_004591 & CCL20 & Chemokine(C-C motif) ligand 2 \\
\hline B2 & NM_053056 & CCND1 & Cyclin D1 \\
\hline B3 & NM_014207 & CD5 & CD5 molecule \\
\hline B4 & NM_001798 & CDK2 & Cyclin-dependent kinase2 \\
\hline B5 & NM_000389 & CDKN1A & $\begin{array}{l}\text { Cyclin-dependent kinase inhibitor 1A (p21, } \\
\text { Cip1) }\end{array}$ \\
\hline B6 & NM_004064 & CDKN1B & $\begin{array}{l}\text { Cyclin-dependent kinase inhibitor 1B (p27, } \\
\text { Kip1) }\end{array}$ \\
\hline B7 & NM_000077 & CDKN2A & $\begin{array}{l}\text { Cyclin-dependent kinase inhibitor 2A } \\
\text { (melanoma, p16, inhibits CDK4) }\end{array}$ \\
\hline B8 & NM_004936 & CDKN2B & $\begin{array}{l}\text { Cyclin-dependent kinase inhibitor 2B (p15, } \\
\text { inhibits CDK4) }\end{array}$ \\
\hline B9 & NM_005194 & CEBPB & CCAAT/enhancer binding protein (C/EBP), beta \\
\hline
\end{tabular}




\begin{tabular}{|c|c|c|c|}
\hline B10 & NM_000758 & CSF2 & $\begin{array}{l}\text { Colony stimulating factor } 2 \text { (granulocyte- } \\
\text { macrofage) }\end{array}$ \\
\hline B11 & NM_002416 & CXCL9 & Chemokine(C-X-C motif) ligand 9 \\
\hline B12 & NM_000103 & CYP19A1 & $\begin{array}{l}\text { Cytochrome P450, family 19, subfamily A, } \\
\text { polypeptide } 1\end{array}$ \\
\hline $\mathrm{C} 01$ & NM_001964 & EGR1 & Early growth response 1 \\
\hline $\mathrm{C} 02$ & NM_001426 & EN1 & Engrailed homeobox 1 \\
\hline $\mathrm{C} 03$ & NM_000043 & FAS & Fas (TNF receptor superfamily, member 6) \\
\hline $\mathrm{C} 04$ & NM_000639 & FASLG & Fas ligand (TNF superfamily, member 6) \\
\hline $\mathrm{C} 05$ & NM_004104 & FASN & Fatt acid syntase \\
\hline $\mathrm{C} 06$ & NM_002026 & FN1 & Fibronectin 1 \\
\hline $\mathrm{C} 07$ & NM_005252 & FOS & $\begin{array}{l}\text { V-fos FBJ murine osteosarcoma viral oncogene } \\
\text { homolog }\end{array}$ \\
\hline $\mathrm{C08}$ & NM_021784 & FOXA2 & Forkhead box A2 \\
\hline $\mathrm{C09}$ & NM_001924 & GADD45A & Growth arrest and DNA-damage-inducible, alpha \\
\hline $\mathrm{C} 10$ & NM_014668 & GREB1 & GREB1 protein \\
\hline $\mathrm{C} 11$ & NM_002103 & GYS & Glycogen syntase 1 (muscle) \\
\hline $\mathrm{C} 12$ & NM_000189 & HK2 & Hexokinase 2 \\
\hline D01 & NM_005522 & HOXA1 & Homeobox A1 \\
\hline D02 & NM_005526 & HSF1 & Heat shock transcription factor 1 \\
\hline D03 & NM_001540 & HSPB 1 & Heat shock 27 kDa protein 1 \\
\hline D04 & NM_001040141 & HSP90AA2 & $\begin{array}{l}\text { Heat shock protein } 90 \mathrm{kDa} \text { alpha (cytosolic) } \\
\text { class A member } 2\end{array}$ \\
\hline D05 & NM_000201 & ICAM 1 & $\begin{array}{l}\text { Intercellular adhesion molecule } 1(\mathrm{CD} 54) \text {, human } \\
\text { rhinovirus receptor }\end{array}$ \\
\hline D06 & NM_000598 & IGFBP3 & Insulin-like growth factor binding protein 3 \\
\hline D07 & NM_001556 & IKBKB & $\begin{array}{l}\text { Inhibitor of Kappa light polypeptide gene } \\
\text { enhancer in B cells, kinase beta }\end{array}$ \\
\hline D08 & NM_000575 & IL1A & Interleukin 1 , alpha \\
\hline
\end{tabular}


continuação

\begin{tabular}{|c|l|l|l|}
\hline D09 & NM_000586 & IL2 & Interleukin 2 \\
\hline D10 & NM_000589 & IL4 & Interleukin 4 \\
\hline D11 & NM_000418 & IL4R & Interleukin 4 receptor \\
\hline D12 & NM_000584 & IL8 & Interleukin 8 \\
\hline E01 & NM_002198 & IRF1 & Interferon regulatory factor 1 \\
\hline E02 & NM_002228 & JUN & Jun oncogene \\
\hline E03 & NM_005551 & KLK2 & Kalikrein-related peptidase 2 \\
\hline E04 & NM_016269 & LEF1 & Lymphoid enhancer-binding factor 1 \\
\hline E05 & NM_000230 & LEP & Leptin (obesity homolog, mouse) \\
\hline E06 & NM_000595 & LTA & $\begin{array}{l}\text { Lymphotoxin alpha (TNF superfamily, member } \\
\text { 1) }\end{array}$ \\
\hline E07 & NM_002392 & MDM2 & $\begin{array}{l}\text { Mdm2, transformed 3T3 cell double minute 2, } \\
\text { p53 binding protein (mouse) }\end{array}$ \\
\hline E08 & NM_002425 & MMP10 & Matrix metallopeptidase 10 (stromelysin 2) \\
\hline E09 & NM_002423 & MMP7 & Matrix metallopeptidase 7 (matrilysin, uterine) \\
\hline E10 & NM_002467 & MYC & $\begin{array}{l}\text { V-myc myelocytomatosis viral oncogene } \\
\text { homolog (avian) }\end{array}$ \\
\hline E11 & NM_003998 & NFKB1 & $\begin{array}{l}\text { Nuclear factor of kappa light polypeptide gene } \\
\text { enhancer in B-cells 1 (p105) }\end{array}$ \\
\hline E12 & NM_000625 & NOS2A & $\begin{array}{l}\text { Nitric oxide synthase 2A (inducible, } \\
\text { hepatocytes) }\end{array}$ \\
\hline F01 & NM_003489 & NRIP1 & Nuclear receptor interacting protein 1 \\
\hline F02 & NM_002539 & ODC1 & Ornithine decarboxylase 1 \\
\hline F04 & NM_000442 & PECAM1 & $\begin{array}{l}\text { Platelet/endothelial cell adhesion molecule } \\
\text { (CD31 antigen) }\end{array}$ \\
\hline NM_015869 & NM_005400 & PRKCE & Protein kinase C, epsilon \\
\hline NM_000264 & PTCH1 & Pacthed homolog 1 (Drrosophila) \\
\hline gamma
\end{tabular}




\begin{tabular}{|c|c|c|c|}
\hline F08 & NM_000963 & PTGS2 & $\begin{array}{l}\text { Prostaglandin-endoperoxide syntase } 2 \\
\text { (prostaglandin } \mathrm{G} / \mathrm{H} \text { syntase and cyclooxigenase) }\end{array}$ \\
\hline F09 & NM_002899 & RBP1 & Retinol binding protein 1, cellular \\
\hline F10 & NM_000450 & SELE & Selectin E (endothelial adhesion molecule 1) \\
\hline F11 & NM_003006 & SELPLG & Selectin P ligand \\
\hline F12 & NM_004180 & TANK & $\begin{array}{l}\text { TRAF family member-associated NKKB } \\
\text { activator }\end{array}$ \\
\hline G01 & NM_003202 & TCF7 & $\begin{array}{l}\text { Transcription factor } 7 \text { (T-cell specific, HMG- } \\
\text { box) }\end{array}$ \\
\hline G02 & NM_198255 & TERT & Telomerase reverse transcriptase \\
\hline G03 & NM_003234 & TFRC & Transferrin receptor \\
\hline G04 & NM_020182 & TMEPAI & $\begin{array}{l}\text { Transmembrane, prostate androgen induced } \\
\text { RNA }\end{array}$ \\
\hline G05 & NM_000594 & TNF & $\begin{array}{l}\text { Tumor necrosis factor (TNF superfamily, } \\
\text { member 2) }\end{array}$ \\
\hline G06 & NM_000546 & TP53 & Tumor protein p53 (Li-Fraumeni syndrome) \\
\hline G07 & NM_004881 & TP53I3 & Tumor protein p53 inducible protein 3 \\
\hline G08 & NM_001078 & VCAM & Vascular cell adhesion molecule 1 \\
\hline G09 & NM_003376 & VEGFA & Vascular endothelial growth factor A \\
\hline G10 & NM_003882 & WISP1 & WNT1 inducible signaling pathway protein 1 \\
\hline G11 & NM_005430 & WNT1 & $\begin{array}{l}\text { Wingless-type MMTV integration site family, } \\
\text { member } 1\end{array}$ \\
\hline G12 & NM_003391 & WNT2 & $\begin{array}{l}\text { Wingless-type MMTV integration site family, } \\
\text { member } 2\end{array}$ \\
\hline $\mathrm{H} 01$ & NM_004048 & B2M & Beta-2-microglobulin \\
\hline $\mathrm{H} 02$ & NM_000194 & HPRT1 & $\begin{array}{l}\text { Hypoxanthine phosphoribosyltransferase } 1 \\
\text { (Lesch-Nyhan syndrome) }\end{array}$ \\
\hline $\mathrm{H} 03$ & NM_012423 & RPL13A & Ribosomal protein L13a \\
\hline H04 & NM_002046 & GAPDH & Glyceraldehyde-3-phosphate dehydrogenase \\
\hline H05 & NM_001101 & АСТВ & Actin, beta \\
\hline
\end{tabular}


conclusão

\begin{tabular}{|l|l|l|l|}
\hline H06 & SA_00105 & HGDC & Human genomic DNA contamination \\
\hline H07 & SA_00104 & RTC & Reverse transcription control \\
\hline H08 & SA_00104 & RTC & Reverse transcription control \\
\hline H09 & SA_00104 & RTC & Reverse transcription control \\
\hline H10 & SA_00103 & PPC & Positive PCR control \\
\hline H11 & SA_00103 & PPC & Positive PCR control \\
\hline H12 & SA_00103 & PPC & Positive PCR control \\
\hline
\end{tabular}


ANEXO B- Relação dos valores médios das concentrações das citocinas obtidas para cada amostra de tecido gengival dos pacientes apresentado diferentes condições periodontais: periodontite agressiva (PAG), periodontite crônica (PC) e periodonto saudável (S).

\begin{tabular}{|c|c|c|c|}
\hline \multirow{2}{*}{ Pacientes } & \multicolumn{3}{|c|}{ Citocinas } \\
\hline & TNF- $\alpha$ & ICAM-1 & GM-CSF \\
\hline PAG1 & 6779,23 & 1146961,58 & 4860,87 \\
\hline PAG2 & 4453,23 & 170516,53 & 2186,58 \\
\hline PAG3 & 9327,76 & 283994,79 & 6044,74 \\
\hline PAG4 & 8433,92 & 851489,70 & 8408,85 \\
\hline PAG5 & 3023,64 & 190716,62 & 914,53 \\
\hline PAG6 & 6583,87 & 1156278,22 & 71737,66 \\
\hline PAG7 & 3308,20 & 384837,47 & 11740,90 \\
\hline PAG8 & 5440,54 & 1179663,20 & 16405,65 \\
\hline PAG9 & 9878,40 & 333893,07 & 23509,99 \\
\hline PAG10 & 6879,05 & 2234579,01 & 74253,36 \\
\hline PC1 & 5013,98 & 1146961,98 & 3010,83 \\
\hline PC2 & 7153,25 & 252469,74 & 2520,48 \\
\hline PC3 & 5832,13 & 1425811,74 & 1164,05 \\
\hline PC4 & 4901,35 & 1023276,62 & 1605,87 \\
\hline PC5 & 5877,95 & 611025,65 & 8947,01 \\
\hline PC6 & 8349,76 & 167168,53 & 20710,39 \\
\hline PC7 & 5247,97 & 467006,53 & 589,05 \\
\hline PC8 & 3284,93 & 540049,61 & 70116,61 \\
\hline PC9 & 5247,97 & 631048,11 & 53411,24 \\
\hline PC10 & 4840,71 & 1290173,70 & 4493,98 \\
\hline $\mathrm{PC} 11$ & 625,00 & 72398,25 & 26079,05 \\
\hline S1 & 2660,08 & 22032,64 & 16814,41 \\
\hline S2 & 603,78 & 54250,18 & 0 \\
\hline S3 & 0 & 29572,32 & 0 \\
\hline S4 & 5609,53 & 40759,62 & 8399,39 \\
\hline
\end{tabular}


conclusão

\begin{tabular}{|l|c|c|c|}
\hline S5 & 1950,98 & 153829,90 & 0 \\
\hline S6 & 0 & 75340,20 & 0 \\
\hline S7 & 0 & 2614,15 & 0 \\
\hline S8 & 0 & 11796,25 & 0 \\
\hline S9 & 0 & 8624,59 & 0 \\
\hline S10 & 64,10 & 130010,61 & 0 \\
\hline S11 & 0 & 69166,45 & 644,40 \\
\hline S12 & 0 & 34315,30 & 0 \\
\hline
\end{tabular}

